Portland State University

PDXScholar

\title{
Community level impacts associated with the invasion of English ivy (Hedera spp.) in Forest Park: a look at the impacts of ivy on community composition and soil moisture
}

Sara Rose Copp

Portland State University

Follow this and additional works at: https://pdxscholar.library.pdx.edu/open_access_etds

Part of the Environmental Sciences Commons, and the Plants Commons Let us know how access to this document benefits you.

Recommended Citation

Copp, Sara Rose, "Community level impacts associated with the invasion of English ivy (Hedera spp.) in Forest Park: a look at the impacts of ivy on community composition and soil moisture" (2014). Dissertations and Theses. Paper 2024.

https://doi.org/10.15760/etd.2023

This Thesis is brought to you for free and open access. It has been accepted for inclusion in Dissertations and Theses by an authorized administrator of PDXScholar. Please contact us if we can make this document more accessible: pdxscholar@pdx.edu. 
Community level impacts associated with the invasion of English ivy (Hedera spp.) in Forest Park: a look at the impacts of ivy on community composition and soil moisture.

\title{
by
}

\section{Sara Rose Copp}

A thesis submitted in partial fulfillment of the requirements for the degree of

\author{
Master of Science \\ in \\ Environmental Science and Management
}

Thesis Committee:

Marion Dresner, Chair

Jeffrey Gerwing

Jocelyn Mueller

Portland State University

2014 


\section{ABSTRACT}

Invasive species degrade ecosystems by altering natural processes and decreasing the abundance and diversity of native flora. Communities with major fluctuations in resource supply allow invasive species to exploit limiting resources making the community prone to invasion. In the Pacific Northwest, urban forests characterized with limited light and seasonally limited soil moisture are being dominated by nonnative English ivy (Hedera spp). Three observational studies were conducted in the Southern end of Forest Park within the Balch Creek Subwatershed in Portland, Oregon in order to understand 1) how English ivy changes over three growing seasons, 2) how the native understory composition responds to English ivy, 3) if the dominance of English ivy reduces soil moisture to neighboring plants, 4) how English ivy and two co-occurring native herbs (Hydrophyllum tenuipes and Vancouveria hexandra) physiologically respond to seasonal changes in soil moisture. Percent cover of the understory community was collected in both 2010 and 2013 growing seasons in 54 plots in order to understand the change in cover over time. Community response and the relationship with soil moisture was analyzed using percent cover of the understory community and associated environmental variables including soil moisture collected in 128 plots during the 2013 field season. Finally, 15 plots with co-occurring Hedera spp, $H$. tenuipes and $V$. hexandra were sampled for stomatal conductance, leaf water potential, and associated environmental variables. Results show ivy cover increases on average $14 \%$ between 2010 and 2013 while native understory cover increased on average $<1 \%$. Once ivy forms dense cover over $44 \%$ there is a reduction of native richness, diversity and herb cover 
while also an increase in available soil moisture and deciduous canopy cover. There were disparate impacts to different functional groups and between species. As functional group, the herbaceous community was the most impacted by ivy invasion. The shrubs and fern community had a variable response to ivy invasion. Many of the fern and shrub species least impacted by ivy also had associations with high soil moisture and deciduous canopy cover. Finally, data suggests that ivy does not take advantage of seasonally limiting soil moisture to invade the understory community. This study indicates that English ivy is both efficient at water use and may have the ability to obtain water from distant locations throughout the forest. Once established, ivy has the ability to alter the community composition. Ivy removal and habitat restoration are essential in order to maintain and enhance biodiversity in Forest Park. 


\section{ACKNOWLEDGEMENTS}

I would like to thank Dr. Marion Dresner for her guidance and support throughout this study. Thanks to my thesis committee Dr. Joceyln Mueller and Dr. Jeff Gerwing for providing valuable feedback. Thanks to Dr. Sarah Eppley, Dr. Todd Rosenstiel, Dr. Alan Yeakley, Dr. Josh Caplan, and Bianca Dolan who provided inspiration and input for this study. Thank you to the Bureau of Land Management for the support and flexibility throughout my time in graduate school. Thanks to John Willoughby who always went out of his way to guide me in research design. Thank you to Dr. Linda George, Dr. Alan Yeakley, Dr. Sarah Eppley, Dr. Marion Dresner, and Jill Van Winkle for providing equipment necessary for this study. Thank you to Mehmet Balkan for training me to use the pressure bomb. Thank you to the Forest Park Permanent Plot Research Crew, Katie Farmer, and Corinne Handelman for helping me collect data. Thank you to Dr. Yangdong Pan, Greg Lewallen, Roberta Brunkalla, Blair Edwards, and Meredith Jordan for assistance with data analysis and interpretation. Thank you to Monica Mogilewsky and Vicki Meyers for editing my thesis. Thank you to my support system at Portland State University who gave me research advice and helped me remain sane throughout graduate school, especially Jill Van Winkle, Corinne Handelman, Blair Edwards, Lindsey Karr, and Meredith Jordan. Thank you to my fiancé Pete Franz and my family George, Gabby, and Adam Copp for the constant encouragement, love, and support. Thank you to all of my friends, near and far, who are always rooting for me. 


\section{Table of Contents}

$\begin{array}{ll}\text { ABSTRACT } & \text { i }\end{array}$

ACKNOWLEDGMENTS $\quad$ iii

\begin{tabular}{ll} 
LIST OF TABLES & V \\
\hline
\end{tabular}

LIST OF FIGURES Vii

\begin{tabular}{ll} 
INTRODUCTION & 1 \\
\hline
\end{tabular}

BACKGROUND $\quad 3$

IMPORTANCE OF FOREST UNDERSTORIES

FACTORS INFLUENCING FOREST UNDERSTORY SPATIAL DISTRIBUTION $\mathbf{3}$

ENGLISH IVY (HEDERA SPP.)

MECHANISMS OF INVASION

UNDERSTORY SPECIES ADAPTATIONS TO THE PNW MOISTURE REGIME 12

\begin{tabular}{lr} 
RESEARCH HYPOTHESES & 15 \\
\hline
\end{tabular}

\begin{tabular}{lr} 
METHODS & 18 \\
\hline
\end{tabular}

$\begin{array}{ll}\text { STUDY AREA } & \mathbf{1 8}\end{array}$

A) STUDY DESIGN AND STATISTICAL ANALYSES: HYPOTHESIS ONE, TWO, AND THREE

B) STUDY DESIGN AND STATISTICAL ANALYSES: HYPOTHESIS FOUR $\quad \mathbf{3 0}$

RESULTS $\quad 36$

HYPOTHESIS 1: CHANGE OVER TIME

HYPOTHESIS 2: CHANGE IN COMMUNITY COMPOSITION

HYPOTHESIS 3: CHANGE IN SOIL MOISTURE

HYPOTHESIS 4: CHANGES IN WATER RELATIONS

\begin{tabular}{ll} 
DISCUSSION & 75 \\
\hline
\end{tabular}

CONCLUSIONS AND MANAGEMENT IMPLICATIONS $\quad 85$

\begin{tabular}{lr} 
STUDY LIMITATIONS AND FUTURE RESEARCH & 87 \\
\hline
\end{tabular}

\begin{tabular}{lr} 
CONCLUDING REMARKS & 88 \\
\hline
\end{tabular}

\begin{tabular}{lr} 
REFERENCES & 89 \\
\hline
\end{tabular}

\begin{tabular}{ll} 
APPENDIX & 101 \\
\hline
\end{tabular} 


\section{LIST OF TABLES}

Table 1: Mean cover ( \pm standard error) of English ivy, total native understory, herb, shrub, and fern for year 2010 and 2013. Paired t-tests of each variable between the 2010 and 2013 growing season show that mean cover of English ivy increased on average $14 \%$, total native understory increased on average $0.27 \%$, native herb cover increased on average $1.06 \%$, and native fern cover increased on average $3.5 \%$ over time while native shrub cover does not change. (Page 37)

Table 2: ANOVA and Tukey HSD post hoc tests for herb cover, shrub cover, fern cover, total diversity, and evenness across the three ivy cover categories: low (0-12.75), medium (12.75-43.75), and high (43.75-98.75) show significant differences across ivy densities. Herb cover and diversity in low plots are significantly different than high plots. Shrub cover in medium plots was significantly different than low and high plots. Fern and evenness does not change across ivy densities. A Kruskal Wallis nonparametric ANOVA and Kruskal multiple comparison test for richness across low, medium, and high ivy cover categories show a significant difference in richness in high ivy plots compared to low ivy plots. Different lowercase letters in the same row indicate significant differences $(\mathrm{P}<0.05)$ across the ivy cover categories. (Page 41)

Table 3: OLS regression and a paired ANOVA examining the relationship between native herb, shrub, and fern cover across the gradient (0-97.5\%) of English ivy cover. With increasing densities of ivy cover, herb and shrub cover will decrease while ferns show no response. (Page 45)

Table 4: Kruskal Wallis nonparametric ANOVA and Kruskal comparison test for each of the common understory species across low (0-12.75\%), medium (12.75-43.75\%), and high (43.75-98.75\%) ivy cover categories. Native understory species responded differently to the three densities of ivy cover. The cover of most species did not change across the ivy densities. Seven species showed lower cover in high ivy plots while two species showed higher cover in high ivy plots. Significant understory predictors of community composition were established by fitting a species vector on a non-metric multidimensional scaling plot. Asterisks or different lowercase letters represent significant differences between plots $(\mathrm{P}<0.05)$. Bold represents species that significantly changed across the three ivy cover categories. (Page 50)

Table 5: Table of relative abundance and significant $(\mathrm{P}<0.05)$ indicator species of common understory species across the three ivy cover categories: low (0-12.75), medium (12.75-43.75), and high (43.75-98.75). The relative abundance of understory species varied across the three ivy cover categories. Four species were significant indicators of low ivy cover plots, no species were indicators of medium ivy plots, and only one species was the indicator of high ivy plots. Bold indicates the ivy category where species has the highest relative abundance and species that significantly change across the ivy cover categories. (Page 51) 
Table 6: Pair-wise ANOSIM test showed a significant change in community composition between the three English ivy cover groups, low (0-12.75\%), medium (12.75-43.75\%), and high (43.75-98.75\%). * P-value with Bonferroni correction $(<0.0167)$. (Page 56)

Table 7: Multiple linear regression of the predictors of the VWC of the soil. There is a significant relationship between VWC and English ivy cover, litter depth, slope, and overstory conifer cover (Page 63)

Table 8: Mean total precipitation and mean departure from normal precipitation in Portland, Oregon between May 1, 2013 and October 1, 2013. Data show unseasonably high rains in September 2013. (Page 69)

Table 9: Mean \pm SE vapor pressure deficit (VPD) for predawn and midday sampling times across early, mid, and late summer water relation data collection. (Page 69)

Table 10: Kruskal Wallis nonparametric ANOVA with a Kruskal multiple comparison test for predawn and midday sampling periods across seasons showing differences in vapor pressure deficit (VPD) across the three sampling periods. Different lowercase letters represent significant difference $(\mathrm{P}<0.05)$. (Page 70)

Table 11: Mean and standard error of VWC of soil and species specific water status measurements across the three sampling periods- early summer, mid-summer, and late summer. Additionally, an analysis of variance and Tukey HSD post hoc test was performed and different small letters represent variables that are statistically significant $(\mathrm{P}<0.05)$. Codes were used for clarity: $H$. tenuipes (HYTE), V. hexandra (VAHE), English ivy (Ivy), Stomatal conductance $\left(\mathrm{g}_{\mathrm{s}}\right)$ measured in $\mathrm{mmol} \mathrm{m} \mathrm{m}^{-2}$, predawn and midday water potential ( $\Psi \mathrm{pd}, \Psi \mathrm{md})$ measured in megapascals (MPa), and volumetric water content (\%VWC). (Page 71) 


\section{LIST OF FIGURES}

Figure 1: Forest Park study area and two forest research sites located in the southern management unit in the Balch Creek Subwatershed in Portland, Oregon. (Page 20)

Figure 2: Location of Balch Creek and Coyote Research plots located in the southern management unit of Forest Park in Balch Creek Subwatershed in Portland, Oregon.

(Page 21)

Figure 3: Arrangement of 1-hectare research plots. Each 1-hectare plot systematically divided into $1625 \mathrm{~m}$ x 25m subplots; each subplot is divided into 4 microplots. (Page 23)

Figure 4: Total diversity ( $\left.\mathrm{H}^{\prime}\right)$ as a function of square-root transformed English ivy cover. A OLS regression show that there was a significant $(\mathrm{F}=8.01, \mathrm{P}=0.005)$ but weak negative $\left(\mathrm{R}^{2}=0.07\right)$ correlation between diversity and English ivy cover. (Page 39)

Figure 5: A general linear model (GLM) showing how total native understory richness $(\mathrm{S})$ was negatively $(\mathrm{P}<0.001)$ associated with square-root transformed English ivy cover. This model explained $17.85 \%$ of total (null) deviance seen in native species richness with an AIC of 101.03 (Page 40)

Figure 6: Mean total diversity (H') across the three ivy cover categories: low (0-12.75), medium (12.75-43.75), and high (43.75-98.75). An ANOVA showed that diversity was lower in high ivy plots compared to medium and low. Error bars represent $95 \%$ confidence interval. Different lowercase letter indicates significant difference between ivy cover groups $(\mathrm{P}<0.05)$. (Page 42)

Figure 7: Mean total native understory richness across the three ivy cover categories: low (0-12.75), medium (12.75-43.75), and high (43.75-98.75). Richness was broken down by understory functional group, blue represents total richness, green represents shrub richness, purple represents fern richness, and red represents herb richness. A Kruskal Wallis nonparametric ANOVA showed that richness was significantly lower in high ivy plots compared to low ivy plots. The decreases in total richness decreases across the ivy cover categories in primarily explained by a decrease in herb richness. Error bars represent $95 \%$ confidence interval. Different lowercase letters indicate significant difference between groups $(\mathrm{P}<0.05)$. (Page 43)

Figure 8: Mean cover of native functional groups (fern and allies, herb, and shrub) across the three ivy cover categories: low (0-12.75), medium (12.75-43.75), and high (43.7598.75). Multiple ANOVAs showed that herb cover is significantly lower in high ivy plots compared to medium and low, whereas shrub cover was lower in medium ivy plot compared to low and ivy. Different lowercase letters within functional groups indicate significant a difference between cover categories $(\mathrm{P}<0.05)$. Italicized letters show 
changes in shrub cover, and bold letters show changes in herb cover. Error bars represent 95\% confidence interval. (Page 46)

Figure 9: Mean percent cover of the understory species that significantly changed ( $\mathrm{P}>0.05$; Table 4) across low (0-12.75\%), medium (12.75-43.75\%), and high (43.7598.75\%) ivy cover categories. A) Kruskal Wallis ANOVA showed a reduction in mean cover for A. triphylla, Carex spp., D. hookeri, G. triflorum, V. glabella, while A. filixfemina showed higher cover in high ivy plots. $B$ ) Kruskal Wallis ANOVA and multiple comparison test showed a reduction in P. munitum and M. nervosa across the ivy cover categories. Error bars represent 95\% confidence interval. (Page 49)

Figure 10: NMDS plot of survey sites grouped by low, medium and high Hedera spp. cover categories. The three Hedera spp. coverage categories: 0-12.75\% (black circles), $12.75-43.75 \%$ (red triangles), and $43.75-98.75 \%$ (green plus) are delimited by color coordinated ovals. Ovals contain the majority of sites within a group, and emphasize plot location. The three dimensional plot stress is 0.165 . NMDS I represents $25 \%$ and NMDS II represents $16.7 \%$ of the total original Bray-Curtis dissimilarity matrix. (Page 54)

Figure 11: Boxplot of ANOSIM (Analysis of Similarity) Test showing a significant change in community composition between the percent ivy cover groupings and within each group. ANOSIM uses a bootstrap randomization using the Bray-Curtis dissimilarity measure with 999 permutations to determine the portability of group membership based on within-stand verse between stand variance within a community. Results are shown at top and significant $(\mathrm{R}=0.242, \mathrm{p}=0.001)$. (Page 55)

Figure 12: NMDS triplot of sampling sites (black circles) and plant species (red crosses). Plant species' vectors are superimposed (blue arrows) displaying the vector magnitude (length) and direction. Also displayed are the vector plant species coefficients for NMDS I and II. Species codes are used in this plot for clarity: Achlys triphylla(ACTR), Asarum caudatum(ASCA), Athyrium filix-femina (ATFI), Claytonia sibrica (CLSI), Disporum hookeri (DIHO), Galium triflorum (GATR), Geranium robertianum (GERO), Hydrophyllum tenuipes (HYTE), Mahonia nervosa (MANE), Polysticum munitum (POMU), Maianthemum stellatum (SMST), Trientalis borealis ssp. latifolia (TRLA), Tolmiea menziesii (TOME), Vancouveria hexandra (VAHE), Hedera spp. (HEHE). (Page 57)

Figure 13: Bubble plots of the dominant functional groups in the forest understory community composition. NIS cover is primary a function of Hedera spp. cover. Clear clustering by functional group is evident, contributing to the separation of the sites within the ordination space. The ovals represent ivy cover categories, green is high ivy cover, red represents medium ivy cover, and blue represents low ivy cover. Bubbles of increasing size represent increasing abundance. (Page 58) 
Figure 14: NMDS triplot of sample site (black circles) and species (red crosses) overlain with environmental variable vectors (blue arrows). Deciduous tree and conifer tree represent percent overstory canopy cover. Table of environmental variable coefficients is included at bottom left. Three dimensional plot stress is 0.165 . (Page 59)

Figure 15: Contour plots of the four significant $(\mathrm{P}>0.05)$ environmental variables superimposed on NMDS ordination plot. Three dimensional plot stress is 0.165 . A blue arrow shows the increase in the environmental gradient. Soil moisture and deciduous canopy cover explain high ivy cover sites while litter depth and conifer canopy cover explain low ivy cover sites. (Page 60)

Figure 16: Mean VWC of the soil across the three ivy cover categories: low (0-12.75), medium (12.75-43.75), and high (43.75-98.75). VWC significantly $(\mathrm{P}=0.03, \mathrm{~F}=3.599)$ increased from low ivy cover to high ivy cover. Error bars represent $95 \%$ confidence interval. Different lowercase letters indicate significant difference $(\mathrm{P}<0.05)$. (Page 62)

Figure 17: Volumetric water content (VWC) of the soil as a function of log transformed slope, square root transformed conifer cover, log transformed litter depth, and square root transformed English ivy cover. The multiple linear regression showed that slope, ivy cover, conifer canopy cover, and litter depth significantly $(\mathrm{R} 2=0.52, \mathrm{~F}=33.49, \mathrm{P}<0.001)$ explains the variability in VWC across the community. (Page 64)

Figure 18: Total precipitation in Portland, Oregon between May 1, 2013 and October 1, 2013. Precipitation data comes from the NOAA meteorological station at the Portland International Airport. (Page 68)

Figure 19: Mean predawn water $\left(\Psi_{\mathrm{pd}}\right)$ potential for the three co-occurring study species across the three sample periods: early summer, mid-summer, and late summer. As the summer progressed, predawn water potential for the two native herbs becomes less negative while English ivy potential does not change. Error bars represent 95\% confidence interval. (Page 72)

Figure 20: Mean stomatal conductance (gs) for the three co-occurring study species across the three sample periods: early summer, mid-summer, and late summer. As the summer progressed, the stomatal conductance for the two native herbs decreases while English ivy conductance does not change. Error bars represent 95\% confidence interval. (Page 73)

Figure 21: Mean midday water potential $\left(\Psi_{\mathrm{md}}\right)$ for the three co-occurring study species across the three sample periods: early summer, mid-summer, and late summer. As the summer progressed, mid-day water potential for the two native herbs becomes less negative while English ivy potential does not change. Error bars represent 95\% confidence interval. (Page 74 


\section{Introduction:}

Each year in the United States, almost $\$ 120$ billion dollars is spent on environmental damages and losses related to nonnative invasive species (Pimentel et al., 2005). Invasive species defined by Executive Order 13312 are " alien species whose introduction does or is likely to cause economic or environmental harm or harm to human health". Invasive species cause environmental damages by altering ecosystem processes including disturbance regimes, hydrology, nutrient cycling, and reducing global biodiversity (Alvarez \& Cushman, 2002; Gilbert \& Lechowicz, 2005; Levine et al., 2003; Meyerson \& Mooney, 2007; Urgenson et al., 2009). At a community level, nonnative species alter native plant distributions and decrease diversity by suppressing native plants (Hejda et al., 2009; Urgenson et al., 2009). Communities subject to fluctuations in resource supply are more susceptible to invasion because of the greater opportunity for invasive species to exploit limited resources; thus reducing resources for the local species (Davis et al., 2000).

The dominance of English ivy (Hedera spp.) in the urban, temperate forests of the Pacific Northwest has led managers to spend thousands of dollars each year on chemical and mechanical removal (ODA b). English ivy is thought to alter the understory composition (Waggy, 2010), yet the only published study on ivy invasion shows a reduction in shrub cover, and no change in understory species diversity (Dlugosch, 2005). Native understories assist in ecosystem function and are essential in maintaining biodiversity (Gilliam, 2007); however such little is known about how English ivy alters 
the understory composition. The mechanisms of English ivy invasion are only now becoming known. In forests with limited light and seasonally limited soil moisture (Waring \& Franklin, 1979) English ivy has been known to exploit the winter light below a deciduous canopy for vigorous vegetative expansion (Holloway \& Rosenstiel, 2013). Additional mechanisms of invasion are unknown, specifically if English ivy uses the fluctuation in water resource supply to invade the forest understories.

This study aims to examine how English ivy shifts the understory community composition and observes the relationship between seasonally limiting soil moisture and the dominance of English ivy in a temperate, urban park in Portland, Oregon.

\section{Importance of forest understories:}

Forest understories, composed of seedlings, saplings, shrubs, ferns, herbs, graminoids, bryophytes, and lichen, provide important roles in forest structure and composition (Franklin et al., 2002). Understory plants maintain biodiversity, and provide wildlife food and habitat (Gilliam, 2007; Miller et al., 2002). The understory can also influence the overstory composition; ultimately affecting succession by both serving as a nursery for canopy trees, and by interacting with a fire regime to influence vegetation composition and ecosystem functioning (Gilliam, 2007; Miller et al., 2002; Nilsson \& Wardle, 2005). Understory plants can also modify resources by altering light availability and influencing nutrient cycling, nutrient availability, and plant growth (Gilliam, 2007; Miller et al., 2002; Nilsson \& Wardle, 2005). Although the total aboveground biomass of the understory is small relative to the forest as a whole, it has significant ecosystem level impacts including mediating carbon dynamics and energy 
flow, and a disproportionate impact to cycling rates of essential nutrients (Gilliam, 2007).

\section{Factors influencing forest understory spatial distribution}

In the temperate mixed conifer and deciduous forests of the Pacific Northwest, the distribution and heterogeneity of the understory species is a result of forest complexity, environmental gradients, disturbance, competition, and the interaction between these variables (Franklin \& Spies, 1991; Spies \& Franklin, 1991). Forest complexity of temperate forests includes overstory composition, large snags, a range of tree sizes and ages, canopy gaps, heavily shaded sites (Antigaps), and down woody debris (Franklin and Spies, 1991; Spies \& Franklin, 1991). These complexities create variability in environmental variables such as coarse woody debris, soil moisture, nutrients, light, and temperature (Franklin and Spies, 1991; Franklin et al., 2002; Gray et al., 2002; Klinka et al., 1996; Pabst \& Spies, 1997).

Overstory canopy species play an influential role in understory composition by regulating the limiting factors of the forest. Overstory species influence the light transmission into the understory, regulate soil chemical properties, influence nutrient cycling, provide shading and insulation, and alter hydrological conditions by redirecting precipitation and removing soil water through transpiration (Finzi et al., 1998; Klinka et al., 1996; Prescott, 2002).

Pacific Northwest temperate forests are characterized with limited light and limited soil moisture during the growing season (Waring \& Franklin, 1979). Limiting factors impact community distribution by favoring stress tolerant species (Grime, 1977) 
able to effectively capture light in heavily shaded environments and able to avoid moisture stress (Bailey et al., 1998; Fahey \& Puettmann, 2008; Nelson et al., 2007; North et al., 2005; Turner \& Begg, 1981). Both light and soil moisture influence the understory community composition (Franklin et al., 2002; McKenzie et al., 2000; North et al., 2005). Shrubs and early seral and release herbs tend to dominate in areas with high light transmission common in a canopy gaps or after a disturbance, but as the understory becomes severely light limited the understory community composition shifts to a dominance of late-seral shade-tolerant herbs (Bailey et al., 1998; Franklin et al., 2002; Klinka et al., 1996; McKenzie et al., 2000). A site with drier soil tends to favor species associated with and adapted to warmer and drier climates such as salal (Gaultheria shallon), pacific blackberry (Rubus ursinus), twinflower (Linneae borealis), and sword fern (Polysticum munitum) while a wetter soil favors species adapted to cold and wet climates such as maple (Acer circinatum), foamflower (Tiarella trifoliata), wild ginger (Asarum caudatum), vanilla leaf (Achlys triphylla), and inside-out flower (Vancouveria hexandra) (Lookingbill et al., 2004). Gradients of these limiting resources contribute to the spatial pattern and heterogeneity of the understory community.

Because many factors influence the distribution of understory composition, the understory community is thought to be resilient to environmental change even after severe disturbances (Bailey et al., 1998). Yet these 'resilient' communities are gradually becoming dominated and subsequently altered by nonnative English ivy (Hedera spp.; No Ivy League, 2005). 


\section{English ivy (Hedera spp.)}

One of the most common nonnative species in Pacific Northwest temperate urban forests is English ivy. Once established, English ivy appears to reduce native species and alter forest composition (Dlugosch, 2005; Soll, 2005). Invasive ivy is commonly referred to as Hedera helix in the Pacific Northwest, yet genetic testing of ivy populations in British Colombia, Washington, and northern Oregon found that most of the populations (83\%) were H. hibernica (Clarke et al., 2006). Some argue that $H$. hibernica is one of the 400 subspecies of $H$. helix and is not a distinct species (Metcalf, 2005). Since both species can be found in the Pacific Northwest (USDA a and b; Wisehard et al., 2011), and the specific subspecies at the study site was not confirmed, Hedera spp. will hereafter be referred to as English ivy.

English ivy (Hedera spp.; Araliaceae) is native to Eurasia introduced as an ornamental in the colonial era (Reichard, 2000). It has established in most of the lower 48 United States, but is widely considered a problem in the lowland forests of the Pacific Northwest and the Atlantic seaboard (Metcalf, 2005; Ramsey, 2005). The occurrences in these zones are bound by latitude (Ramsey, 2005). On the Pacific coast, invasive ivy is common in western California, Oregon, Washington, and southern British Columbia, but absent from northern British Columbia and Alaska (Ramsey, 2005). English ivy was used commonly as an ornamental in commercial and residential landscaping and sold by nurseries in Oregon until 2010 when it was banned by the Oregon Department of Agriculture (ODA a). Although it has been banned from horticultural use it continues to spread into natural areas (Personal observation). 
English ivy is an evergreen, woody vine (liana) with waxy, dark green, long-lived (3-4 years) leaves that roots around $9.6 \mathrm{~cm}$ below soil surface (Metcalf, 2005; Waggy, 2010; Sack et al., 2003). Ivy has two distinct growth phases: the juvenile vegetative phase and the adult sexual reproductive phase (Okerman 2000; Reichard, 2000; Waggy, 2010). During the vegetative phase, English ivy grows from 6-8 inches tall, and spreads along the forest floor, forming continuous cover (Metcalfe, 2005; Waggy, 2010). During the adult phase, English ivy produces clusters of greenish white flowers and begins to climb vertical structures, reaching heights of 30m (Okerman, 2000). The juvenile phase can last 10 years or more (Diedrich, 2009; Ramsey, 2005; Waggy, 2010).

English ivy flowers from May to June when it is pollinated by wasps, bees, and flies and produces dark, purple fleshly berries the following spring (Okerman, 2000; Waggy, 2010). English ivy spreads vigorously by bird dispersal and vegetatively by fragmented or advancing roots and stems (Soll, 2005). Dispersal in North America is common by both native and nonnative frugiverous birds including European starlings, stellar jays, house sparrows, and American robins while European blackbirds are common dispersal agents in its native range (Ramsey, 2005; Sorensen, 1984; Swearingen \& Diedrich, 2009). Seeds that have been cleaned, manually or by bird regurgitation result in almost $100 \%$ germination, but seeds have a short dormancy and do not form a soil seed bank (Waggy, 2010; Metcalfe, 2005).

English ivy is tolerant of a range of soil moisture, light, and nutrient environmental conditions (Grime et al., 1988, Metcalf, 2005; Waggy, 2010). English ivy is stress tolerant allowing it to establish in a range of environments and communities 
(Waggy, 2010); however local environmental factors can also strongly influence growth and abundance of ivy (Ramsey, 2005). As a member of the tropical Araliaceae family, ivy benefits from a temperate climate with warm dry summers, and cool wet winters, yet appears to be limited by freezing temperatures (Metcalfe, 2005). Ivy thrives in sites with moist, fertile, clay-rich soils, and is tolerant yet less abundant on poor, well-drained, very dry, or waterlogged sandy soils (Grime et al., 1988; Metcalf, 2005; Thomas, 1990).

Seedlings and recruitment may be limited by available soil moisture; Ramsey (2005) found that seedlings occurred most frequently in years with more rainfall in addition to in habitat with high levels of soil moisture and organic matter. Once established, the low evapotranspiration rates (Feldman et al., 1997) allow ivy to be tolerant of a wide range of moisture regimes; vegetative expansion is unlikely to be affected by seasonal drought (Metcalf, 2005; Thomas, 1980). English ivy shows moderate plasticity allowing it to maximize photosynthesis in a variety of light conditions (Metcalf, 2005; Waggy, 2010). Leaves in the adult phase have 1.5 times higher photosynthetic capacity than juvenile leaves allowing them to thrive in full sun at the top of the canopy (Metcalf, 2005; Soll, 2005). Ivy also has the ability to store photosynthetic energy throughout the winter to be used for growth in late spring and throughout the summer (Holloway \& Rosenstiel, 2013). During early spring, ivy takes advantage of the extra light on the forest floor, especially in areas under a deciduous canopy, by increasing photosynthetic capacity; energy is stored in the leaf to be used for growth later in the season (Holloway \& Rosenstiel, 2013). Ivy populations under a mixed conifer and deciduous canopy show increased specific leaf mass and greater vine growth rates following spring time canopy 
closure compared to ivy populations under a conifer canopy cover (Holloway \& Rosenstiel, 2013)

Once established, English ivy can impact the community by altering the structure of the forest, and excluding understory species. English ivy relies on neighboring structures for support (Metcalf, 2005). As ivy reaches the adult stage it climbs trees canopies where the additional weight of the vines can weaken trees and make the overstory more susceptible to wind storms; altering the structural complexity of the forest (Soll, 2005). In the understory, ivy forms a dense patch of continuous cover that appears to reduce native diversity, richness, and cover (Okerman, 2000; Ramsey, 2005; Quinn \& Best, 2002). Studies have found that ivy invasion was associated with reductions of native shrub cover (Dlugosch, 2005) and native species diversity (Ramsey, 2005).

Given the impact that English ivy has on forest health, forest managers are motivated to use a variety of management methods to remove it from the forest. Managers use manual, mechanical, and chemical methods in order to remove English ivy. Manual and chemical removal in some Oregon parks reaches approximately $\$ 2000$ per acres (ODA b). The City of Portland also uses volunteer groups like No Ivy League to educate the public and manually remove ivy from city parks (PPR, 2014). Since 1994, the No Ivy League has worked with 25,377 workers and volunteers to remove 103.42 acres of English ivy (PPR, 2014). Although managers have been consistently treating ivy populations in urban parks, overall English ivy continues to thrive and spread in the PNW forests (Soll, 2005). Understanding impacts to local 
understory species and mechanisms behind the invasion is essential for the future management of the urban temperate forests.

\section{Mechanisms of Invasion:}

The mechanism of nonnative invasive species (NIS) invasion into a habitat can be attributed to both biotic and abiotic factors. The rate at which nonnative species invade an ecosystem is dependent on the susceptibility of the environment to invasion (invasibility), propagule pressure, and invading species traits (Alvarez \& Cushman, 2002; Davis et al., 2000; Lockwood et al., 2005; Mitchell et al., 2006).

The invasibility of an environment is dependent on the regional climate, disturbance regime, and competitive abilities of local species (Davis et al., 2000; Lonsdale, 1999; Tomasetto et al., 2013). Natural or anthropogenic disturbance results in an open forest canopy, reduced competition and increased resource availability, consequences which facilitate NIS establishment by creating an "invasive window." Capable of rapid growth, high propagule pressure, and resource exploitation, NIS ultimately become entrenched and spread by outcompeting the native species (D'Antonio and Meyerson 2002; D’Antonio and Vitousek 1992; Lockwood et al., 1997; Simberloff, 2009). The theory of fluctuating resource availability suggests that environments subject to innate fluctuations in resource supply, are therefore more susceptible to invasion because of the greater opportunity for NIS to exploit limited resources (Davis et al., 2000). As a result, NIS with the ability to exploit limited resources will ultimately reduce resources for the local, native species. The limiting light and seasonally limiting soil moisture seen in Pacific Northwest urban forests (Waring \& Franklin, 1979) may allow 
for increased susceptibility to ivy invasion. Increased light seen in the winter and early spring in deciduous dominated forests can be exploited for increased growth by English ivy (Holloway \& Rosenstiel, 2013). Also, ivy may have the ability to exploit seasonally limited soil moisture by competitively excluding local species.

Propagule pressure is another important determinant of the probability and longevity of invasion. The larger the propagule size and the more individuals released, the higher probability of nonnative species establishment into a new environment (Lockwood et al., 2007; Simberloff, 2009). Even after introduction, propagule pressure continues to be an important factor in invasion because the more individuals in an environment, the longer the population will persist given drops in birth or survival rates (Lockwood et al., 2007; Simberloff, 2009). Propagule pressure can explain a significant variation in establishment success and may even be of more importance than other mechanisms of invasion (Lockwood et al., 2005; Williams and Fitter, 1996). The ability of English ivy to escape cultivation and establish could be attributed to the vigorous spread from bird dispersal, advancing roots, and broken vegetative fragments (Soll, 2005). Fruit production in cultivated plants found in suburban areas is five times higher than plants in natural areas, suggesting that cultivated plants on private residences are an important source of propagules (Ramsey, 2005). The high fruit production allures native and nonnative frugivores allowing English ivy to disperse into natural areas including forest interiors away from road, trails, and other human disturbances (Ramsey, 2005).

Finally, specific plant traits including allelopathy, plasticity, competitive ability, capacity for resource capture, and the interactions between these abilities can also 
determine which species will be the superior competitor (Tilman \& Grace, 1990).

Alleopathy, the release of phytotoxins by NIS, has been proposed as a theory of invasion success (Bais et al., 2003). There is no concluding evidence that ivy is allelopathic.

Bonanomi et al. (2006) found that decomposing ivy litter, along with $88 \%$ of the tested species, exhibited phytotoxicity. On the other hand, Biggerstaff and Beck (2007) found that once ivy is removed native species would begin to germinate.

Broad environmental tolerance and local adaptation are specific plant traits that allow for a successful invasion of a species into a new community (Sexton et al., 2002; Williams \& Fitter, 1996). Plasticity may allow ivy the ability to become established in a range of environmental conditions (Sexton et al., 2002). Once established, a successful invader, such as ivy, would rapidly adapt in response to local selection pressures such as soil moisture or nutrient gradients, light concentrations, or to resident species, thereby contributing to spread and succeed (Lee, 2002; Richards et al., 2006; Sexton et al., 2002). Unlike native species, ivy has the ability to utilize the photoperiod in these urban forests. Ivy uses increased winter light beneath a deciduous overstory to increase photosynthetic capacity that will be stored in the leaf until later in the season when the products are used for growth (Holloway \& Rosenstiel, 2013).

One of the most important plant traits that allow for the establishment of invasive species is competitive ability. Invasive species with a superior competitive ability, such as ivy, may have the ability to capture large quantities of limiting resources, depleting resources and decreasing abundance, growth rate, and fitness to native co-occurring species (Daehler, 2003; Levine et al., 2003; Violle et al., 2009). The vigorous growth 
and relative height of ivy may strongly impact the community by creating homogenous stands that can outcompete neighboring species for resources (Hejda et al., 2009;

Okerman, 2000; Dlugosch, 2005). Resource based competition theories indicate that increase in biomass or density can also reduce the availability of resources in a community (Violle et al., 2009; Tilman 1986); suggesting that areas with dense ivy may reduce resources such as light and soil moisture to the native understory community. Water is essential for growth and rapid reproduction of ivy; in unseasonably dry years ivy's seedling establishment rate is reduced (Metcalf, 2005; Ramsey, 2005). If ivy has a higher water demand than co-occurring species then during the dry summer growing season ivy may have the ability to exploit limited moisture by reducing availability to neighboring plants. Evergreen lianas found in tropical forests of Bolivia have many similar traits with English ivy, thus may have similar responses to water demand. Tropical lianas have a higher water demand compared to co-occurring species that is satisfied by extensive lateral and vertical root systems (Barker \& Perez-Salicrup, 2000). A similar pattern may be seen in ivy, the extensive connectivity of ivy's shallow, lateral roots (Metcalf, 2005) may allow for resource extraction from both the upper soil layer and horizontally along the long stem.

\section{Understory species adaptations to the PNW moisture regime}

In the temperate forests of the PNW, where rainfall is the only source of water supply, water is one of the variable resources needed for growth (Radosevich et al., 1997; Waring \& Franklin, 1979). Unfavorable moisture regimes during the growing season 
increase evaporative demand causing the stomata on the leaf surfaces to close, reducing water loss, and subsequent carbon dioxide uptake (Barbour et al., 1987; Waring \& Franklin, 1979). The level of water stress necessary to cause the stomata to close varies with the drought tolerance of the species and these adaptations may determine the abundance and distribution of species or functional groups in a particular forest (Barbour et al., 1987; citations in Cai et al., 2009).

Forest understory species in temperate forest communities vary in growth form, phenology, and methods of reproduction (Bierzychudek, 1982) therefore may respond differently to water stress. A well-distributed root system, leaf characteristics that favor water retention, and drought avoidance adaptations allow these species to thrive in these limited conditions (Radosevich et al., 1997; Turner \& Begg, 1981). Many forest understory species have some degree of clonal growth that better enable species to persist under spatially variable resource conditions. Clonal growth habit with extensive belowground connectivity allows the plant to explore greater soil volume and depth for water (Thomas et al., 1999; Turner \& Begg, 1981). Species can possess leaf characteristics that allow them to use water more efficiently including a waxy cuticle, pubescence, sunken stomata, leaf size, ratio of inner surface to outer leaf surface, and orientation (Barbour et al., 1987; Turner \& Begg, 1981). They also have the ability to avoid drought by declining leaf expansion, leaf orientation, senescence, dormancy, and, nighttime carbon dioxide intake (Turner \& Begg, 1981; Hsiao \& Acevedo, 1974). Because many native understory 'shade species' are more limited by light than soil moisture, many species may trade off water use efficiency for efficient light capture 
and chlorophyll production (Nelson et al., 2007). The trade-off may allow species that are more effective at capturing water and dealing with water stress to invade a community.

English ivy has been thought of as a moist-site indicator (Metcalf, 2005). Seedling establishment and recruitment limitation is highly correlated with soil moisture and organic matter (Metcalf, 2005; Ramsey, 2005). Despite being thought of as a moist site indicator, ivy has the ability to adapt to a variable moisture regime one established (Metcalf, 2005; Ramsey, 2005). English ivy, similar to the tropical lianas, has characteristics that allow it to compete well during seasonal droughts. As discussed earlier, ivy is a woody, evergreen vine that can extend over 30 meters across the forest floor (Okerman, 2000). The thick waxy leaves and water conducting tissue is efficient and is able to avoid cavitation (Leuzinger et al., 2011; Metcalf, 2005). Ivy, similar to tropical lianas, relies on other structures such as trees to provide support; this trade-off allows ivy to efficiently transport water and also to save structural tissue, allocating more biomass to photosynthesis tissues by reducing biomass investment to the supporting structures; therefore increasing the growth rate (Leuzinger et al., 2011; Zhu \& Cao, 2009). Lianas compete with understory saplings for belowground resources (Schnitzer, 2005), similar processes could be occurring with ivy and understory species in Forest Park.

Though ivy is known as a competitive invader that thrives in moist soil conditions (Metcalf, 2005), little is known about if it exploits seasonally limited soil moisture in the understory of Forest Park. In forests with limited soil moisture during the growing 
season (Waring \& Franklin, 1979), ivy may be able to rapidly extract soil moisture thus reducing available water to neighboring species. In addition to mechanism of invasion, little is known about how the community responds to ivy invasion. Some studies have shown the negative impacts of ivy to the understory (i.e. shrub reduction and diversity reduction; Dlugosch, 2005; Ramsey, 2005) but a more complete analysis of the change in understory community composition change is unknown. Understanding not only the specific impacts to the understory but also the mechanism by which it invades is essential for effective forest management. 


\section{This Study:}

Three observational studies were conducted in two permanent research plots on the southern end of Forest Park within the Balch Creek Subwatershed in Portland, Oregon in order to observe:

a) how English ivy cover changed between the 2010 and 2013 summer season

b) how English ivy density can shift the understory community composition

c) whether English ivy reduced available soil moisture in areas with dense ivy cover

d) how English ivy and two native co-occurring herbs respond physiologically to seasonally limited soil moisture in the Coyote Research Plot

I hypothesize that on the southern end of Forest Park within the Balch Creek Subwatershed:

1) Over three years, percent cover of ivy will increase more than native understory herbs, shrubs, and ferns.

2) As ivy cover increases the understory community composition will significantly shift as seen by:

a) a reduction in total diversity, evenness, and richness;

b) a reduction in cover and relative abundance of the native understory herbs, shrubs, and ferns; and

c) changes in species dominance across a multidimensional space. 
3) Areas with a high density of ivy cover will have lower soil moisture compared to areas with low ivy density.

4) Under low water availability, common throughout the summer months,

a) English ivy will have high stomatal conductance and less negative water potential, and

b) native co-occurring herbs, Vancouveria hexandra and Hydrophyllum tenuipes, will have low stomatal conductance and more negative water potential. 


\section{Methods:}

Study Area:

Forest Park is a 2,000 hectare forested park located in Portland, Oregon (Figure 1) that extends northwest along the eastside of the Tualatin Mountains along the Willamette River floodplain (Broshot, 2011). Providing wildlife a corridor that is critical to species dispersal, Forest Park connects the Portland Metro area with the Coast Range through undeveloped rural lands. Forest Park is considered a second growth forest having been extensively logged throughout the 19th and 20th centuries, as well as having 566 ha impacted by stand-replacing fires in 1889, 1940 and 1951.

The park receives high precipitation that falls primarily as rain between November to April with mild and very wet winters and cool relatively dry summers (Vander Schaaf. et al., 2006). Soils are composed of Cascade silt loam and Goble silt loam types with an underlying fragipan between 20 and 48 inches deep that prevents water penetration (NRCS, 2014). Elevations in the park range between $20 \mathrm{~m}$ and $335 \mathrm{~m}$ above sea level with slopes that can exceed $30 \%$ grade leading to erosion, slumping, and landslide hazards (Broshot, 2007). The park lies in the Douglas fir (Pseudotsuga menziesii), western hemlock (Tsuga heterophylla) vegetation zone that considers western hemlock and western red cedar (Thuja plicata) as climax species and Douglas fir as early seral species (Broshot, 2011). Forests that have experienced frequent disturbances within this vegetation zone are characterized by the presence of bigleaf maple (Acer macrophyllum), and red alder (Alnus rubra) (Broshot, 2011; Franklin \& Dyrness, 1988). The park has experienced anthropogenic disturbances over the past 200 years. Starting as 
early as 1840 , early pioneers developed trails that traversed the Tualatin Range to facilitate wheat and produce delivery (Kuhn, 2005). Logging in the form of clear-cutting and high-grade logging, where only high quality timber is removed from a stand, were common harvesting techniques that occurred in Forest Park starting prior to 1860 and continuing into the 1900's (Broshot, 2007; Dreshler, 2012). These harvesting methods left highly compacted roads scattered through the park. In 1948, Forest Park was formally dedicated (Munger, 1960) leading to the construction of additional roads and trails. Private development and residences that surround the park have also contributed to edge disturbances and biological invasions. As a result of the continual disturbance, bigleaf maple, red alder, and invasive species, most notably, English ivy (Hedera spp.), dominate much of Forest Park. Balch Creek Subwatershed and park edges are considered to be the epicenters of English ivy infestation, with significantly more infestations than the interior of the Park (No Ivy League, 2005). Local organizations like No Ivy League have been working to remove English ivy and restore biodiversity since 1994 (No Ivy League, 2005), yet English ivy still thrives in Forest Park. 


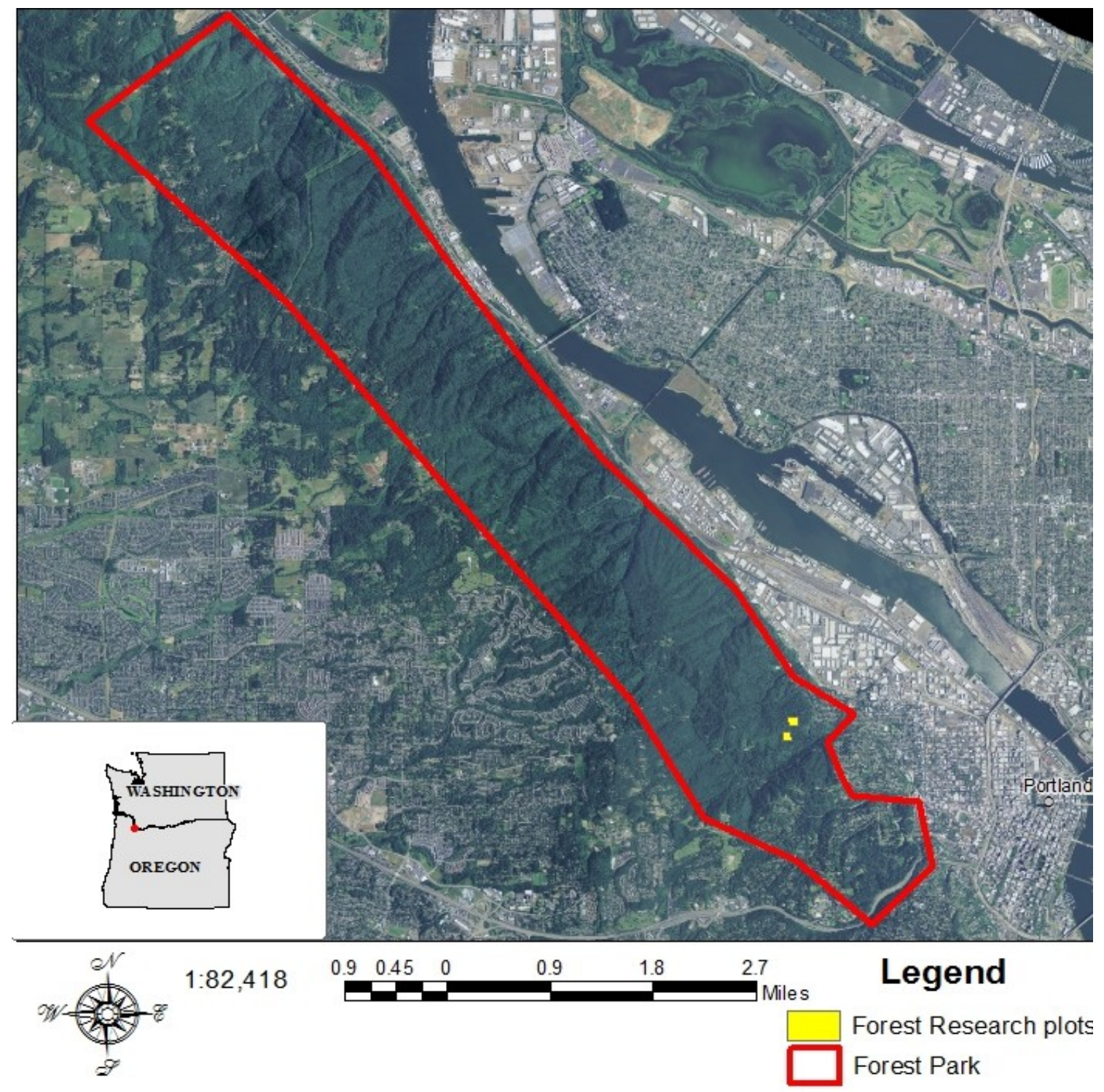

Figure 1: Forest Park study area and two forest research sites located in the southern management unit in the Balch Creek Subwatershed in Portland, Oregon. 


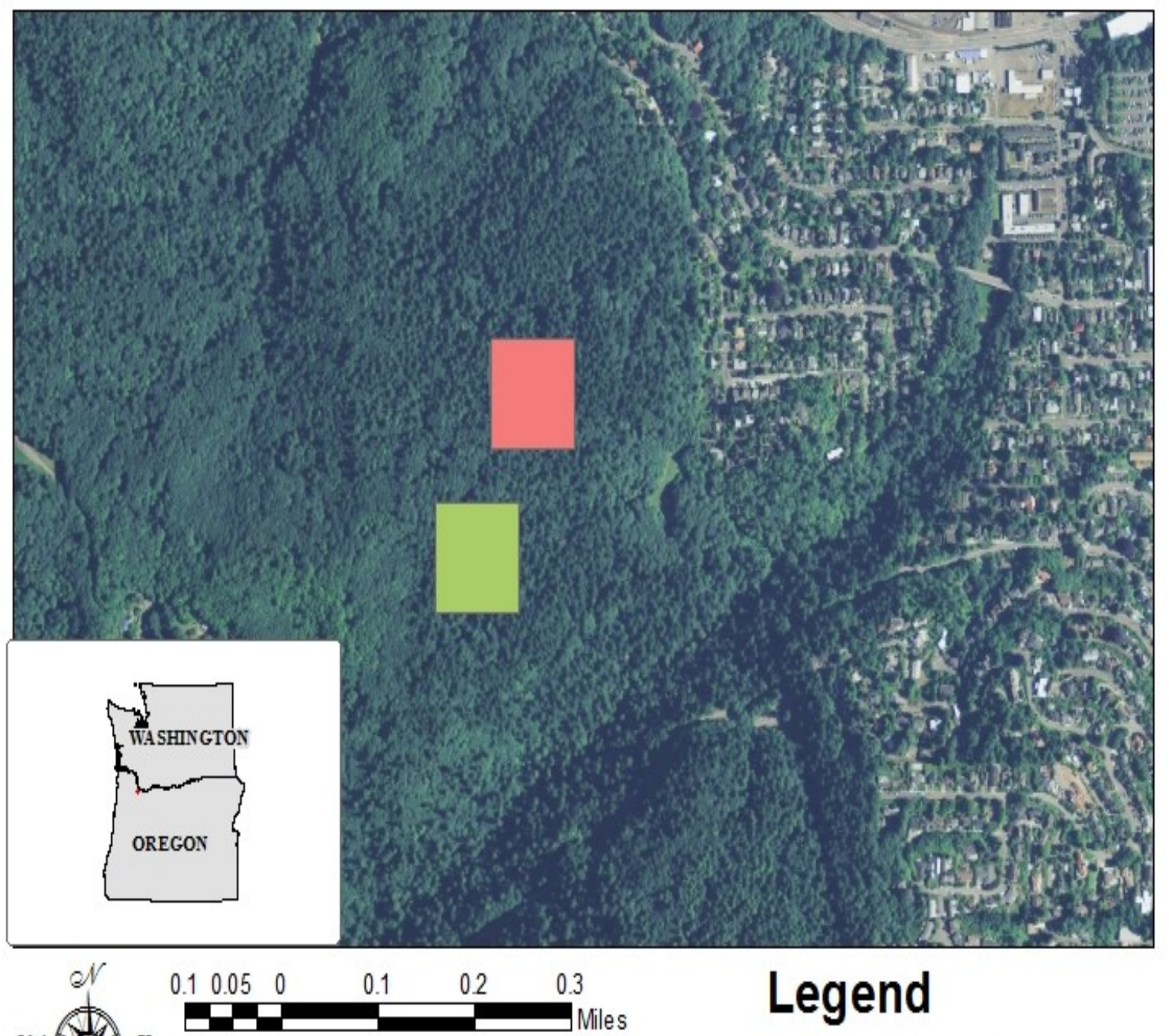

$1: 10,310$

Balch Creek Research Plot

Coyote Research Plot

Figure 2: Location of Balch Creek and Coyote Research plots located in the southern management unit of Forest Park in Balch Creek Subwatershed in Portland, Oregon. 


\section{A) Hypothesis one, two, and three study design:}

To take advantage of pre-existing long-term study plots, we used two 1-hectare $(100 \mathrm{~m} \times 100 \mathrm{~m})$ research plots (Balch and Coyote) in these studies. Balch and Coyote research plots were established during the 2010 and 2012 summer field seasons in the Balch Creek subwatershed in Forest Park by Dr. Marion Dresner and her seasonal field crew, following USDA Forest Inventory and Analysis long-term research site protocol (Figure 2). Both research plots were resampled during the 2013 summer field season by me, Dr. Dresner, and a seasonal field crew. Plot location was selected due to its proximity to the urban side of Forest Park, which has been impacted by land-use history. Each 1-hectare plot is divided into $1625 \mathrm{~m}$ x $25 \mathrm{~m}$ subplots; each subplot is divided into four microplots (Figure 3). During the establishment of the research plots the microplots were $1 \mathrm{~m} \times 1 \mathrm{~m}$, but to increase the portion of the population sampled on the landscape (Elzinga et al., 1998), the microplots were doubled (2m x 1m) during the 2013 field season. 


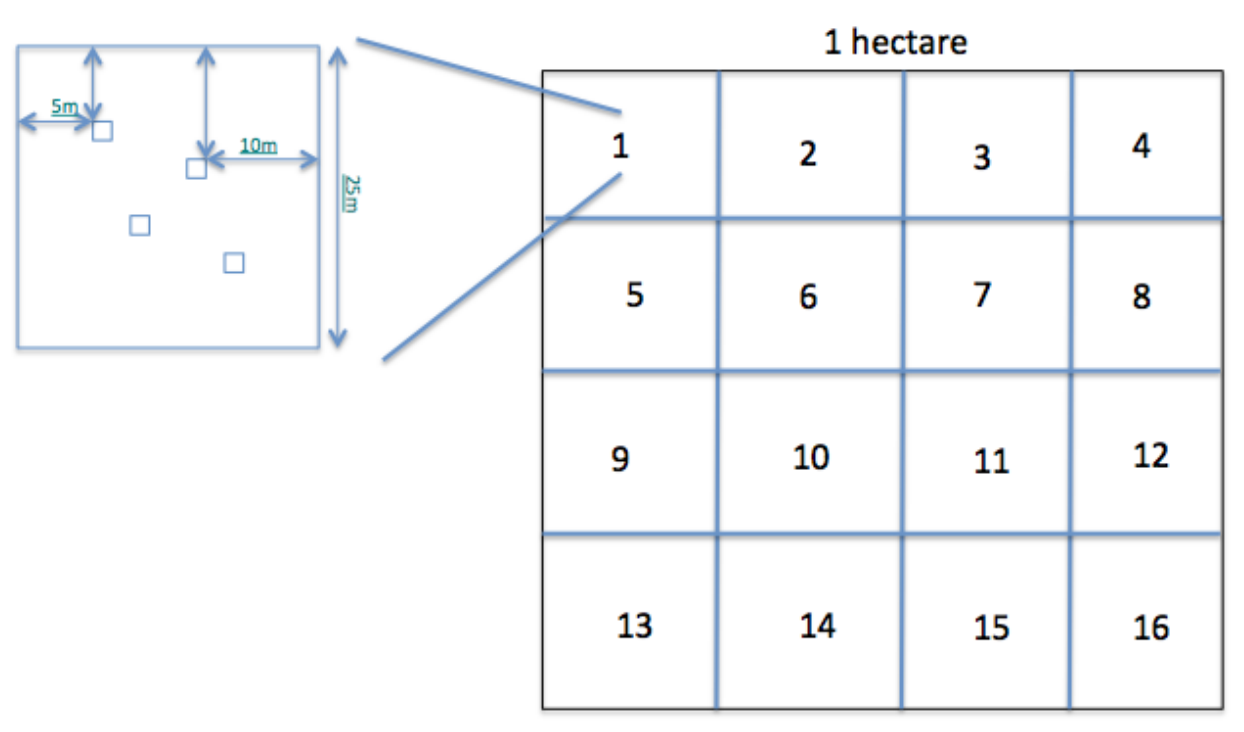

Figure 3: Arrangement of 1-hectare research plots. Each 1-hectare plot systematically divided into $1625 \mathrm{~m} \times 25 \mathrm{~m}$ subplots; each subplot is divided into 4 microplots.

\section{Variables Measured:}

For the 2010, 2012, and 2013 field seasons, we measured percent cover of the herb and low shrub layer, overstory composition, and canopy cover in each microplot. We measured herb and low growing shrub using visual estimates of percent cover in a one meter quadrat. We measured canopy cover using a spherical densitometer, Model A. To measure overstory composition, we used visual estimates of the percent cover of deciduous and conifer. Additional measurements were taken during the 2013 field season including litter depth, soil moisture, slope, and aspect. Four measurements of litter depth were randomly taken at each microplot then averaged. Between September 9September 11, 2013, soil moisture measurements were taken in each microplot within the first $12 \mathrm{~cm}$ of the soil's A horizon, using a HydroSense tensiometer. A tensiometer 
assesses the volumetric water content of the soil by generating an electromagnetic pulse down paired $12 \mathrm{~cm}$ metal rods. The elapsed travel time and pulse reflection are inputted into the data logger that computes volumetric water content $(\theta)$. Ten soil moisture measurements were systematically taken in the center and at each corner of both $1 \mathrm{~m} \times 1 \mathrm{~m}$ sections of the microplot then averaged. Slope was measured using a Suunto cliometer. Aspect was collected using a Suunto MC-2 compass.

Data collected in 2013 at both research plots (Coyote and Balch) were used to understand the changes in community composition and soil moisture $(n=128)$ across different densities of English ivy cover. Data collected in the Balch research site in 2010 and 2013 were used to understand the change of English ivy over time. Twelve microplots in Balch were sampled in 2010 but not resampled in 2013 because of a change in plot placement due to obstructions; these sites were removed from the change in time analysis $(n=52)$.

\section{Data Analysis:}

Species evenness $\left(\mathrm{E}_{\mathrm{var}}\right)$, diversity $\left(\mathrm{H}^{\prime}\right)$, and richness $(\mathrm{S})$ were calculated for each microplot. $\mathrm{E}_{\mathrm{var}}$, was calculated using the relative abundance in each microplot,

$$
E_{v a r}=1-2 / \pi \arctan \left\{\sum_{s=1}^{S}\left(\ln \left(x_{s}\right)-\sum_{t=1}^{S} \ln \left(x_{t}\right) / S\right)^{2} / S\right\}
$$

where $\mathrm{X}_{\mathrm{s}}$ is the abundance of $\mathrm{s}^{\text {th }}, \mathrm{S}$ is the number of species in the sample, and arctan provides an angle in radians. This index is based on the variance in abundance among the species and it is independent of the species richness (Smith \& Wilson, 1996). 
Diversity was calculated using Shannon-Weiner Diversity Index (H') (Spellerberg \& Fedor, 2003).

$$
H^{\prime}=-\sum_{s=1}^{S} p_{s} \ln \left(p_{s}\right)
$$

where $p_{i}$ is the proportion of the ${ }_{i}$ th species, ln pi is the natural logarithm of $p_{i}$, and $s$ is the number of species in the community.

Species cover data were classified and divided into functional groups (native herb, native fern and ally, and native shrub) for analysis (Stinson et al., 2007). Due to the lack of total graminoid cover, graminoid and forb were combined into a larger herb functional group. English ivy cover ranged from $0-97.5 \%$ in the 128 microplots, and were divided into three equal cover categories for analysis using the equal count function in the vegan package in R Studio. The ivy cover category that best described the gradient of ivy cover in a NMDS 3-dimentional ordinations was selected. By selecting three cover categories we were able to have a high number of replicates in each category (Elzinga et al., 1998), equal sample size across cover categories; which allowed us to understand how the community composition changed across different strata of ivy cover. From here forward English ivy cover categories will be classified as low with $0-12.75 \%$ ivy $\operatorname{cover}(\mathrm{n}=44)$, medium with $12.75-43.75 \%$ ivy cover $(n=44)$, and high with $43.75 \%+$ ivy cover $(n=43)$. The relative abundance (species cover at a site/total cover at site) and mean percent ground cover (average of total ground cover over all sites) were determined for common plant species for total plots and for each ivy cover category. 
Statistical Analysis

Hypothesis 1-Over three years, percent cover of ivy will increase more than native understory herbs, shrubs, and ferns:

Between the 2010 and 2013 growing season, 52 plots in the Balch research site were resampled for understory composition and certain environmental variables. To detect change over time, a paired student's t-test was used to examine how cover of ivy and the native functional groups changed between the 2010 and 2013 growing season. Log or square-root transformations were performed to meet assumptions of normality.

Hypothesis $2 a$-As ivy cover increases the native understory community composition will significantly shift as seen by a reduction in total diversity, evenness, and richness.

Ordinary least squares (OLS) regressions were used to analyze how microplot level diversity and abundance ( $H^{\prime}$ and $E_{v a r}$ ) changed in varying degrees of English ivy cover $(0-98.5 \%)$ and with environmental covariates in both Balch and Coyote Research plot $(\mathrm{n}=128 ; \alpha=0.05)$. Because native richness is discrete, a general linear model (GLM) using Poisson distribution with a chi-squared significance test (Bhattarai \& Vetaas, 2003; McCullagh \& Nedler, 1989; Zeileis et al., 2008) was used to understand how species richness (S) changed in varying degrees of English ivy cover. A Kruskal Wallis nonparametric (Gerwing \& Vidal, 2002) analysis of variance (ANOVA) test using the kruskal.test function with Kruskal multiple comparisons tests in the pgirmess package was used to understand how $\mathrm{S}$ changed across the ivy cover categories. An ANOVA was used to understand plot effects $(\alpha=0.05)$ on the diversity indices. Because plot effects 
were non-significant, plots were pooled by cover for subsequent analyses. ANOVA with a Tukey HSD post-hoc analyses were used to understand how $\mathrm{H}^{\prime}$ and $\mathrm{E}_{\mathrm{var}}$ changed in the three categories of English ivy cover. Log or square-root transformations were performed to meet assumptions of normality.

Hypothesis $2 b$ - As ivy cover increases the native understory community composition will significantly shift as seen by a reduction in cover and relative abundance of the native understory herbs, shrubs, and ferns.

Three methods were used to understand how understory cover and relative abundance changed with ivy invasion. First, Kruskal-Wallis nonparametric tests $(\alpha=0.05$; Feir-Walsh \& Toothaker, 1974) and paired Kruskal-Wallis multiple comparison tests were used to understand how cover and relative abundance of individual dominant species changed across the three ivy categories. Next, ANOVA with a Tukey HSD posthoc analysis were used to examine how each native functional group changed across the three ivy categories. Finally, ordinary least squares (OLS) regressions were used to understand the linear relationship between each native functional group along the ivy cover gradient (0-97.5\%; Haitan et al., 2011). Log or square-root transformations were performed to meet the ANOVA and OLS regression assumptions of normality. 
Hypothesis 2c: As ivy cover increases the native understory community composition will significantly shift as seen by changes in species dominance across a multidimensional space.

In order to examine the shifts in understory community composition in response to English ivy invasion a nonmetric multidimensional scale (NMDS) was constructed with understory cover data (vegan package; Clarke,1993). Uncommon species (those with fewer than three occurrences) were removed prior to ordination (Scheller \& Mladenoff, 2002). Species data were log-transformed before NMDS in an attempt to down-weigh the ordination influence of the most frequently observed species and those with the highest percentage of cover. This allowed for less abundant species to contribute to the distribution of NMDS plot patterns or groupings by accentuating site dissimilarity. The NMDS technique graphically depicts dissimilarity between plant communities based on the distance matrix (Parker et al., 2009). NMDS, which maximizes the rank order correlation, was run to calculate the distance matrix using the Bray-Curtis distance measure on the mean percent cover of plant species across all 128 microplots. The stress value, obtained by generating a Shepard's diagram, was calculated to determine how well the Bray-Curtis distance between sites was maintained in comparison to the original data. In order to increase the likelihood of finding the global minimum, several runs were conducted. Twenty iterations, each originating from a randomly chosen position within the MDS space, were performed per run in an attempt to reach a minimum stress value. A 3-dimensional NMDS plot generated the lowest stress value was selected and chosen for further analysis. There was determined to be no 
benefit in presenting the NMDS III axis because the site distribution displayed was not significantly different from NMDS I or NMDS II.

The community composition seen in the NMDS ordination included 27 common native understory species after rare species were removed. The NMDS ordination with the lowest stress $(0.165)$ was used in this analysis. NMDS I explained $25 \%$ of the original Bray-Curtis dissimilarity between survey sites, NMDS II explained 16.7\%, and NMDS III explained and additional 15.9\%. NMDS III was not included in further analyses because it did not add any additional information to the plots.

The environmental fit function (envfit) in the vegan package was used to create triplots by overlaying plot plant species and environmental vectors within the NMDS ordination space. The triplots display the significant $(\mathrm{p}<0.05)$, dominant plant species and environmental drivers responsible for the site configuration of the NMDS ordination. Analysis of similarities (ANOSIM) function in the vegan package was used to test the difference between English ivy cover groups (Clarke, 1993). ANOSIM uses a bootstrap randomization using the Bray-Curtis dissimilarity measure with 999 permutations to determine the probability of group membership based on within-stand versus between stand variance in a community (Parker et al., 2009). In addition, pair-wise ANOSIM with a Bonferroni correction was performed to test the significance between individual ivy cover groups to identify which groups were statistically different from one another. Dufrene-Legendre indicator species analysis function in the labdsv package was used to identify indicator values of fidelity and relative abundance of the common understory 
species in each of the three ivy cover categories. Only the significant $(\mathrm{P}<0.05)$, common species were kept for additional analyses.

Hypothesis 3-Areas with a high density of ivy cover will have lower soil moisture compared to areas with low ivy density:

In order to understand if available soil moisture changed with English ivy cover and environmental covariates (slope, aspect, canopy cover, litter depth overstory conifer cover, and overstory deciduous cover), a multiple linear regression with a hybrid approach using stepwise and criterion based selection process was performed. An ANOVA was performed between the full and reduced model to check if the difference between the means were significant. Data were analyzed using R Studio, version 2012 (R Development Core Team, 2008) using vegan, MASS, and labdsv packages. Graphs and figures were constructed in R Studio or SPSS 19.0.

\section{B) Hypothesis four study design:}

Hypothesis 4- Under low water availability, common throughout the summer months,

a) English ivy will have high stomatal conductance and less negative water potential, and b) native co-occurring herbs, Vancouveria hexandra and Hydrophyllum tenuipes, will have low stomatal conductance and more negative water potential.

Site and species selection:

To examine water relations in Hedera spp. and native herbs, $152 \mathrm{~m}$ x $1 \mathrm{~m}$ plots with co-occurring Hedera spp., H. tenuipes, V. hexandra were sampled on the southwest 
edge of the Coyote Permanent Research Plot located in Forest Park, Portland, Oregon throughout the summer months of 2013. Slope, aspect, canopy cover, and overstory composition were standardized to control for environmental variables that influence water relations (Caplan, 2009). Plots were established $>4 \mathrm{~m}$ apart (Dolan, 2012).

Two dominant, co-occurring herbs were selected for testing:_Hydrophyllum tenuipes (Pacific waterleaf) and Vancouveria hexandra (inside-out flower). Both native species are common in the Forest Park understory, and can be seen growing both in and out of dense patches of ivy (Personal observation). A preliminary unpublished study found no association of $H$. tenuipes decline in high ivy cover while $V$. hexandra cover was associated with a significant decline (Copp, 2012). The physiology, phenology, morphology of these species is different from each other and additionally with English ivy, yet these species colonize in similar locations on the forest floor, are rooted within the same soil depth, and thus may be getting water resources from a similar location. This study did not compare major differences between the three species but rather was used to understand how each species responded to seasonally limiting water seen in the summer months of the PNW.

Hydrophyllum tenuipes:_H. tenuipes (Heller) is a native perennial herb that grows 8-32" tall and blooms from May to July (Giblin, n.d.). It reproduces both from seed and vegetatively, yet it spreads aggressively with rhizomes, and is known to compete with English ivy for space (Pond, 2003). It has a few large leaves $15 \mathrm{~cm}$ long pinnipalmately divided with thinly close-hair on both sides, and tooth leaflets (Giblin, n.d.). It is a shade tolerant species that grows in a mid to late successional, moist mixed conifer and 
hardwood forest (Pond, 2003). H. tenuipes senesces in the winter, and remains dormant underground until environmental conditions initiate spring growth (Personal observation).

Vancouveria hexandra: $V$. hexandra (Hook.) Morr \& Dec. is a native perennial herb that grows 12-18" tall, blooms from May to June, and fruits in the fall (Dyrness \& Acker, 2010). It reproduces both from seed and vegetatively by creeping rhizomes, yet once established it primarily regenerates by vegetative means (Dyrness \& Acker, 2010). The leaves have long petioles and are 10-40 cm long, biternate or incompletely triternate, leaflets with three lobes and sparsely pubescent (Dyrness \& Acker, 2010). It is a moderately shade tolerant species that grows in moist, Douglas fir forests (Dyrness \& Acker, 2010). It tolerates some summer drought but largely performs poorly in hot and dry summers. $V$. hexandra senesces in the winter and remains dormant underground until environmental conditions initiate spring growth (Personal observation). In general there is little information about how these species and currently no published studies have tested the water status of these native herbs in the PNW.

\section{Water relations:}

Leaf water potential and stomatal conductance was used to understand how plants respond to water stress. Plants move water between the soil and atmosphere in response to differences in water potential, for water to move through a plant the water potential of the air must be lower than the moist soil. (Barbour et al., 1987; Gurevitch et al., 2006). Water potential describes the difference in potential energy between pure water and the 
water in a system (Gurevitch et al., 2006). Under steady state conditions, the amount of water plants can acquire from belowground resources (Gurevitch et al., 2006; Jones, 1998; Tuzet et al., 2003). Water movement occurs down a gradient of water potential from higher (less negative) to lower (more negative), as water is drawn out of the plant the potential becomes more negative (Radosevich et al., 1997). Stomata control the water flux through by limiting or facilitating the process of transpiration (Barbour et al., 1987). Stomata open and close in response to seasonal and diurnal variations and environmental conditions such as light, leaf water potential, $\mathrm{CO} 2$ concentrations, and humidity, and vapor pressure deficit (Barbour et al., 1987; Chaves et al., 2002; Gurevitch et al., 2006). The stomatal conductance is a measure of the rate at which carbon dioxide flows into a leaf at a given concentration (Jones, 1998; Tuzet et al., 2003). Because of the absence of transpiration and cavitation in the absence of light, predawn measurements of leaf water potential can be used to as an indicator of soil water availability while midday values are lower and represent conditions of highest temperature (Chaves et al., 2002).

Measurements of water relations and environmental conditions were taken on rain-free days during three months of the 2013 growing season: July 2-3, July 31-Aug 6, and September 10-12. Predawn and mid-day, within a two hour window of solar noon, measurements of water potential ( $\Psi \mathrm{pd}, \Psi \mathrm{md}$ respectively) were taken of herbs in each plot (Zhu \& Cao, 2009). Leaf water potential is a destructive measurement that was taken on one leaf per species per plot using a Model 1000 Scholander-type pressure chamber (Caplan, 2010). Stomatal conductance $\left(\mathrm{g}_{\mathrm{s}}\right)$ is a nondestructive measurement that was taken on three leaves per species per stand (Caplan, 2010) during the mid-day 
measurement rounds. Measurements were made on the abaxial sides of the leaves using a SC-1 leaf porometer. The three measurements were averaged to yield a single stand measurement. The air temperature and relative humidity were logged during collection days using a HOBO U12 data logger. Volumetric water content of the soil was measured (Andrade et al., 2005) within the first 12-cm of the soil's A horizon using a HydroSense tensiometer. Ten soil moisture measurements were systematically taken in the center and at each corner of both $1 \mathrm{~m} \times 1 \mathrm{~m}$ sections of the microplot then averaged. Canopy cover was measured using spherical densitometer, Model A. in each cardinal direction.

\section{Data Analysis}

Vapor pressure deficit was calculated for each sampling time (VPD; Caplan, 2009; Murray, 1967):

$$
V P D=0.611 * e^{\frac{17.27 * \text { Tair }}{\text { Tair }+237.3}}\left(1-\frac{\text { Rhair }}{100}\right)
$$

where $\mathrm{T}_{\text {air }}$ is air temperature $\left({ }^{\circ} \mathrm{C}\right)$ and $\mathrm{RH}_{\text {air }}$ is the relative humidity of the air in percent.

\section{Statistical Analysis:}

Multiple ANOVAs with Tukey HSD post-hoc analyses were used to determine if environmental conditions (average vapor pressure deficit, soil moisture, and predawn water potential) differed between the three measurement periods (early, mid, and late summer; Baker \& Perez-Salicrup, 2000; Caplan, 2009). Multiple ANOVAs with Tukey HSD post-hoc analyses were also used to examine the changes in stomatal conductance and midday water status between the three time periods for each species. Stomatal 
sensitivity to changes in leaf water potential differs among plants (Bazzaz, 1979) therefore I cannot compare water relations across species. Although photosynthetically active radiation (PPFD) is a strong indicator of water relations (Farquhar \& Sharkey, 1982; Radosevich et al., 1997), it was not collected due to inaccessible equipment. Light was not included into the analyses because the only measurement of light collected was overstory canopy cover. Data were analyzed using R Studio, version 2012 (R Development Core Team, 2008) using vegan, MASS, and labdsv packages. Graphs and figures were constructed in R Studio or SPSS 19.0. 


\section{Results:}

Hypothesis 1-Over three years, percent cover of ivy will increase more than native understory herbs, shrubs, and ferns:

Between the summers of 2010 and 2013, the percent cover of English ivy increased on average $14 \%$ (paired t-tests, Tstat $=-4.53, \mathrm{p}<0.001)$ compared to a $0.29 \%($ paired t-tests, Tstat $=-2.13, \mathrm{p}=0.038)$ increase in total native understory, $1.06 \%$ increase of native herb cover (paired t-tests ,Tstat $=-5.29, \mathrm{p}<0.001$ ), 3.5\% of native fern cover (Tstat $=-4.00, \mathrm{p}<0.001$ ), and no increase in native shrub cover (paired t-tests , Tstat $=0.37$, $\mathrm{p}>0.05$; Table 1). Most of the change seen in the native herb and fern community can be attributed to a few dominant species. In the fern and ally functional group, Polysticum munitum increased on average 8.26\% and Athyrium filix-femina increased on average $3.27 \%$. In the native herb functional group, Hydrophyllum tenuipes increased on average $6.8 \%$, Vancouveria hexandra increased on average $2.5 \%$, and Disporum hookeri increased on average $1.8 \%$. While there was a pattern of increase in native herb and fern cover, English ivy cover increases almost double that of the native understory species.

Overall, in the Balch Creek Research Plot thirty-two species were encountered in the summer of 2010 and while 39 species were encountered in 2013 . Of the 32 species in 2010, 15 were native herb spp., five were fern spp. and allies, five were shrub spp., and seven were nonnative species. Of the 39 species in 2013, 20 were native herb spp., five were ferns spp. and allies, nine were shrub spp., and five were nonnative spp. A species list for each plot and for each year can be found in Appendix 1. 
Table 1: Mean cover ( \pm standard error) of English ivy, total native understory, herb, shrub, and fern for year 2010 and 2013. Paired t-tests of each variable between the 2010 and 2013 growing season show that mean cover of English ivy increased on average $14 \%$, total native understory increased on average $0.27 \%$, native herb cover increased on average $1.06 \%$, and native fern cover increased on average $3.5 \%$ over time while native shrub cover does not change.

\begin{tabular}{|c|c|c|c|c|c|c|c|}
\hline \multirow{2}{*}{ Variable } & \multicolumn{2}{|c|}{2010} & \multicolumn{2}{c|}{2013} & \multirow{2}{*}{ t stat } & DF & P-value \\
\cline { 2 - 7 } & $\mathbf{2 0 1 0}$ mean & $\begin{array}{c}\text { Standard } \\
\text { error }\end{array}$ & $\mathbf{2 0 1 3}$ mean & $\begin{array}{c}\text { Standard } \\
\text { error }\end{array}$ & & & \\
\hline $\begin{array}{c}\text { English ivy } \\
\text { cover }\end{array}$ & $26.60 \%$ & \pm 3.89 & $41.43 \%$ & \pm 4.544 & -4.53 & 51.00 & $<\mathbf{0 . 0 0 1}$ \\
\hline $\begin{array}{c}\text { Total } \\
\text { native } \\
\text { understory }\end{array}$ & $1.77 \%$ & \pm 0.174 & $2.06 \%$ & \pm 0.12 & -2.13 & 51.00 & $\mathbf{0 . 0 3 3}$ \\
\hline $\begin{array}{c}\text { Native } \\
\text { herb cover }\end{array}$ & $0.51 \%$ & \pm 0.14 & $1.13 \%$ & \pm 0.156 & -5.29 & 51.00 & $<\mathbf{0 . 0 0 1}$ \\
\hline $\begin{array}{c}\text { Native } \\
\text { shrub } \\
\text { cover }\end{array}$ & $1.60 \%$ & $\pm 0.727 \%$ & $1.06 \%$ & \pm 0.737 & 0.37 & 51.00 & 0.710 \\
\hline $\begin{array}{c}\text { Native fern } \\
\text { cover }\end{array}$ & $5.68 \%$ & \pm 0.45 & $7.60 \%$ & \pm 0.217 & -4.00 & 51.00 & $<\mathbf{0 . 0 0 1}$ \\
\hline
\end{tabular}


Hypothesis $2 a$-As ivy cover increases the native understory community composition will significantly shift as seen by a reduction in total diversity, evenness, and richness.

Overall in the 2013 field season, forty-seven species were encountered in 128 observational sites consisting of 26 native forb and graminoids, 9 native shrubs, 5 native ferns and allies, 7 nonnative herbs and shrubs (Appendix 1A). Overall, results of an OLS regression and GLM show that species diversity $\left(\mathrm{H}^{\prime} ; \mathrm{R}^{2}=0.07, \mathrm{~F}=8.01, \mathrm{P}=0.0005\right)$ and native species richness $\left(\mathrm{S}\right.$; null deviance $\left.=17.85,{ }^{\chi^{2}} \mathrm{P}>0.001\right)$ have a significant but weak negative correlation with increasing English ivy cover (Figure 4, Figure 5).

Alternatively, an OLS regression showed that there was no significant relationship between English ivy cover and species evenness $\left(\mathrm{E}_{\mathrm{var}} ; \mathrm{F}=2.25, \mathrm{P}=0.135\right)$. An ANOVA detected no plot effect on species richness ( $\mathrm{F}=1.713, \mathrm{P}=0.193)$, diversity $(\mathrm{F}=0.156$, $\mathrm{P}=0.693)$, and evenness $(\mathrm{F}=1.938, \mathrm{P}=0.166)$. An OLS regression showed that $\mathrm{H}^{\prime}$ and $\mathrm{S}$ was also not significantly correlated with any of the measured environmental covariatessoil moisture, litter depth, canopy cover, percent overstory cover, litter cover, aspect, and slope $(\mathrm{F}=887, \mathrm{p}=0.529) . \quad$ When examining the diversity indices across the ivy cover categories using an ANOVA, high ivy plots had significantly lower diversity and richness than both low and medium ivy cover categories $\left(\mathrm{F}_{\text {diversity }}=8.01, \mathrm{P}_{\text {diversity }}<0.001,{ }^{\chi^{2}}\right.$ richness $=$ $12.96, \mathrm{P}_{\text {richness }}=0.001$; Figure 6 ) while total evenness did not change across the ivy cover plots $(\mathrm{F}=1.47, \mathrm{P}=0.2336)$. The greatest diversity $(\bar{x}=1.33 \pm 0.055)$ was found in medium ivy cover while the lowest occurred in the high ivy $\operatorname{cover}(\bar{x}=1.05 \pm 0.048 ; \mathrm{P}<0.005$, $\mathrm{F}=8.01$, Table 2). Mean native richness was the greatest in low ivy cover $(\bar{x}=5.68 \pm$ $0.349)$ and significantly decreased to $3.95 \pm 0.324$ in high ivy cover $(\mathrm{P}<0.0016$, 
$\chi 2=12.965)$. The decrease in total richness between low ivy and high ivy can primarily be attributed to the significant reduction of native herb richness from $3.6 \pm 0.285$ in the low ivy to $2.0 \pm 0.297$ in the high ivy $\left({ }^{2}\right.$ herb richness $=17.405$, $P_{\text {herb richness }}=0.0001$, Figure 7).

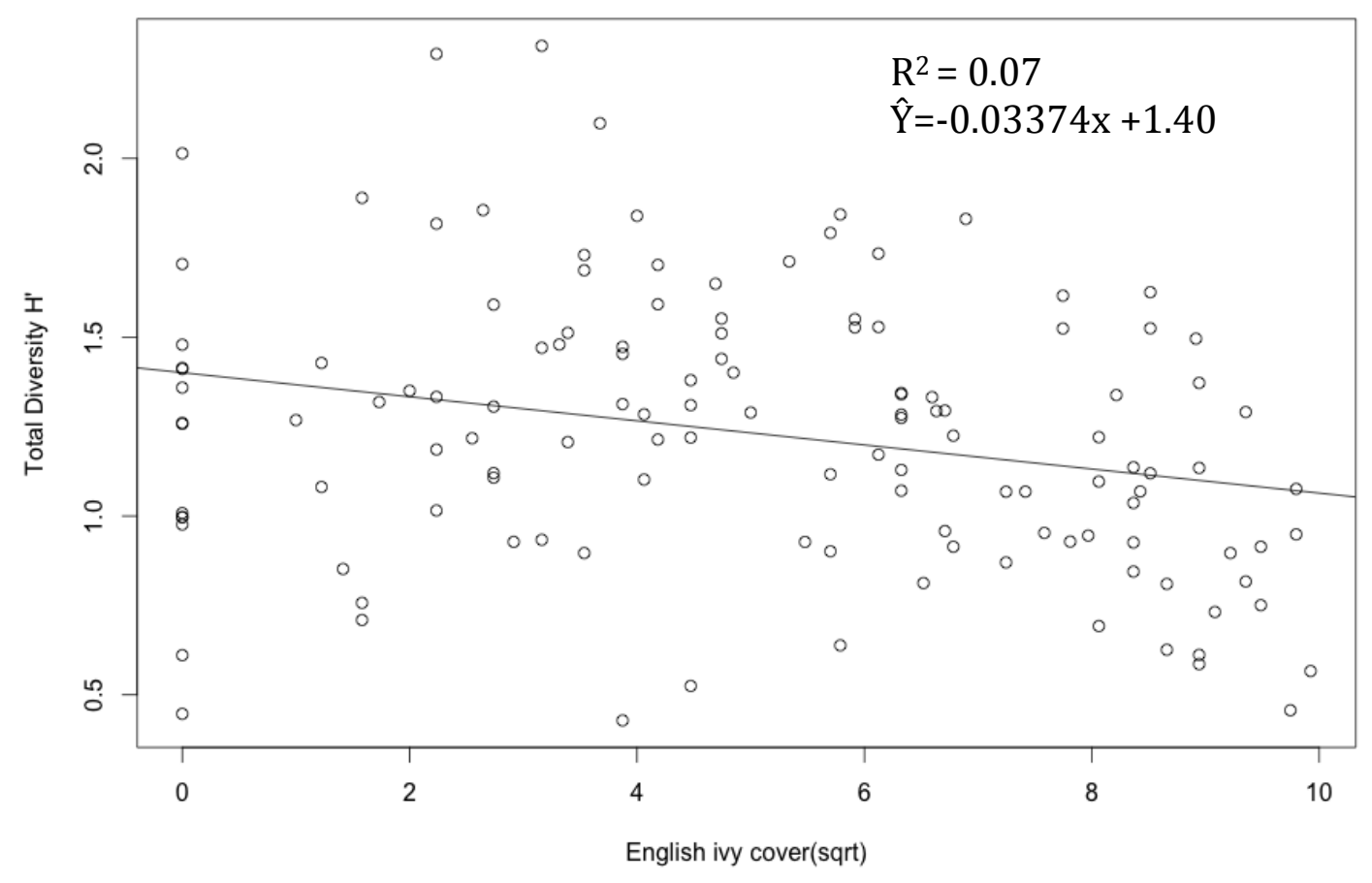

Figure 4: Total diversity $\left(\mathrm{H}^{\prime}\right)$ as a function of square-root transformed English ivy cover. A OLS regression shows that there was a significant $(\mathrm{F}=8.01, \mathrm{P}=0.005)$ but weak negative $\left(\mathrm{R}^{2}=0.07\right)$ correlation between diversity and English ivy cover 


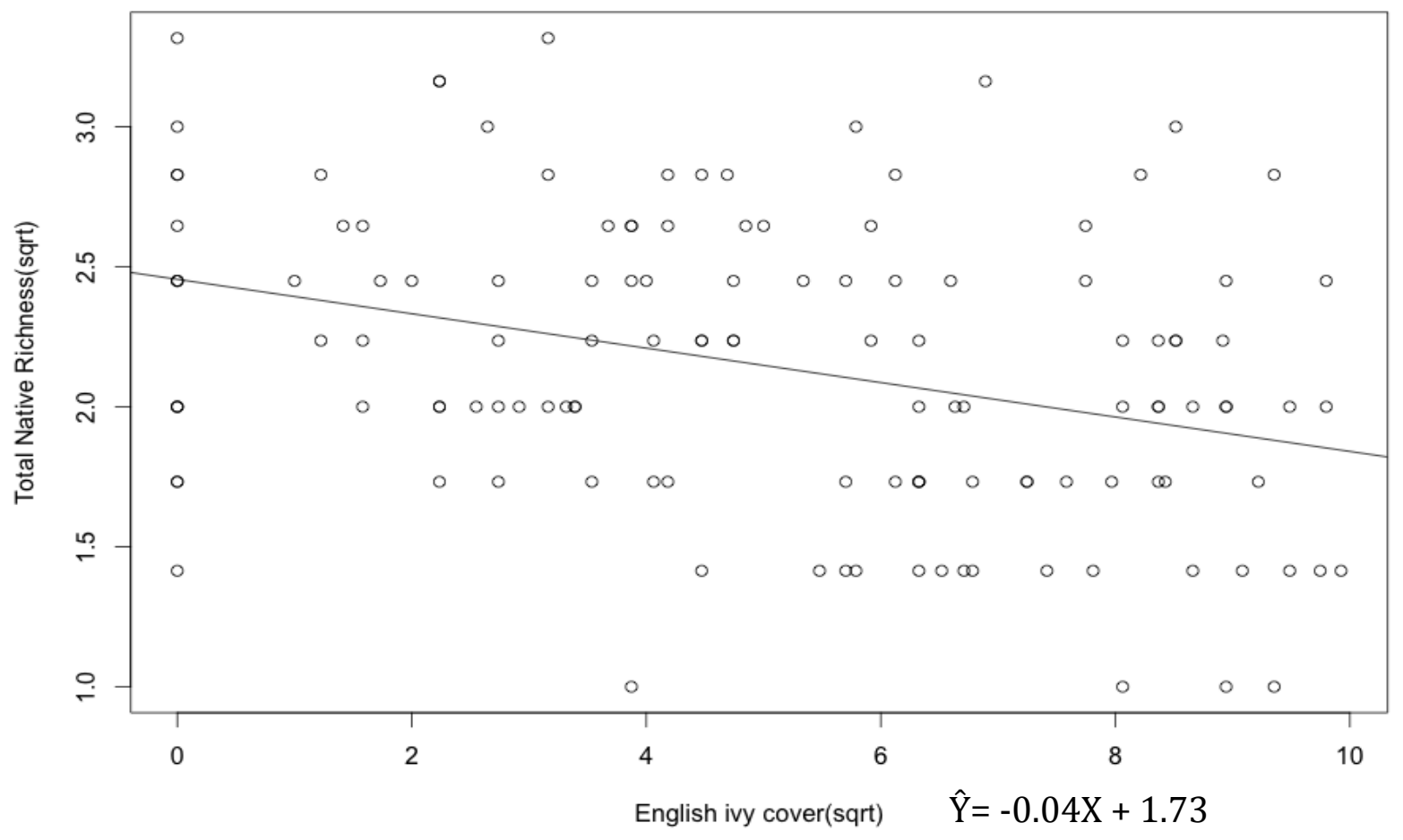

Figure 5: A general linear model (GLM) showing how total native understory richness (S) was negatively $(\mathrm{P}<0.001)$ associated with square-root transformed English ivy cover. This model explained $17.85 \%$ of total (null) deviance seen in native species richness with an AIC of 101.03. 
Table 2: ANOVA and Tukey HSD post hoc tests for herb cover, shrub cover, fern cover, total diversity, and evenness across the three ivy cover categories: low (0-12.75), medium (12.75-43.75), and high (43.75-98.75) show significant differences across ivy densities. Herb cover and diversity in low plots are significantly different than high plots. Shrub cover in medium plots was significantly different than low and high plots. Fern and evenness does not change across ivy densities. A Kruskal Wallis nonparametric ANOVA and Kruskal multiple comparison test for richness across low, medium, and high ivy cover categories show a significant difference in richness in high ivy plots compared to low ivy plots. Different lowercase letters in the same row indicate significant differences $(\mathrm{P}<0.05)$ across the ivy cover categories.

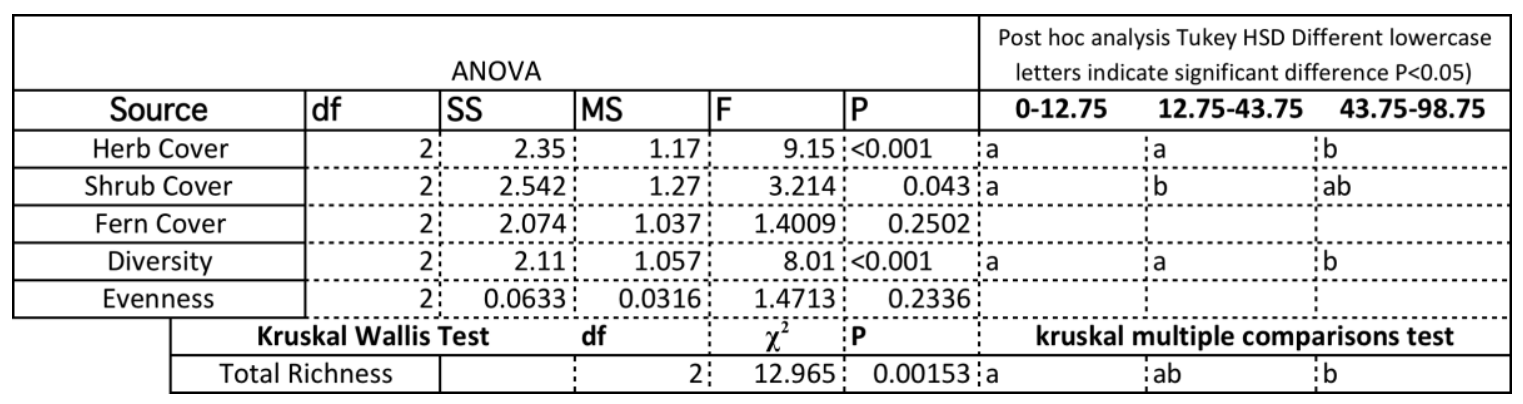




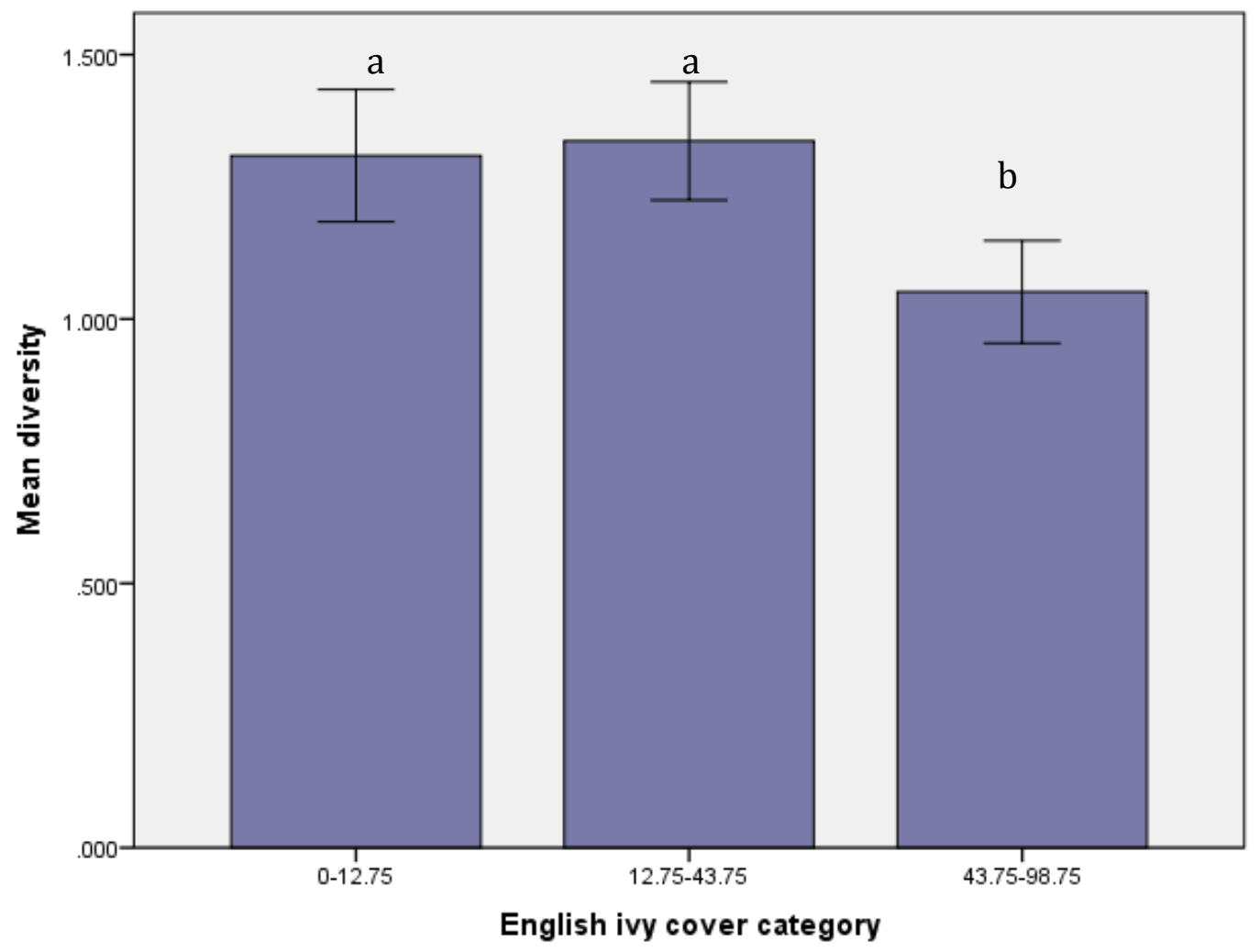

Error bars: $95 \% \mathrm{Cl}$

Figure 6: Mean total diversity ( $\left.\mathrm{H}^{\prime}\right)$ across the three ivy cover categories: low (0-12.75), medium (12.75-43.75), and high (43.75-98.75). An ANOVA showed that diversity was lower in high ivy plots compared to medium and low. Error bars represent $95 \%$ confidence interval. Different lowercase letter indicates significant difference between ivy cover groups $(\mathrm{P}<0.05)$. 


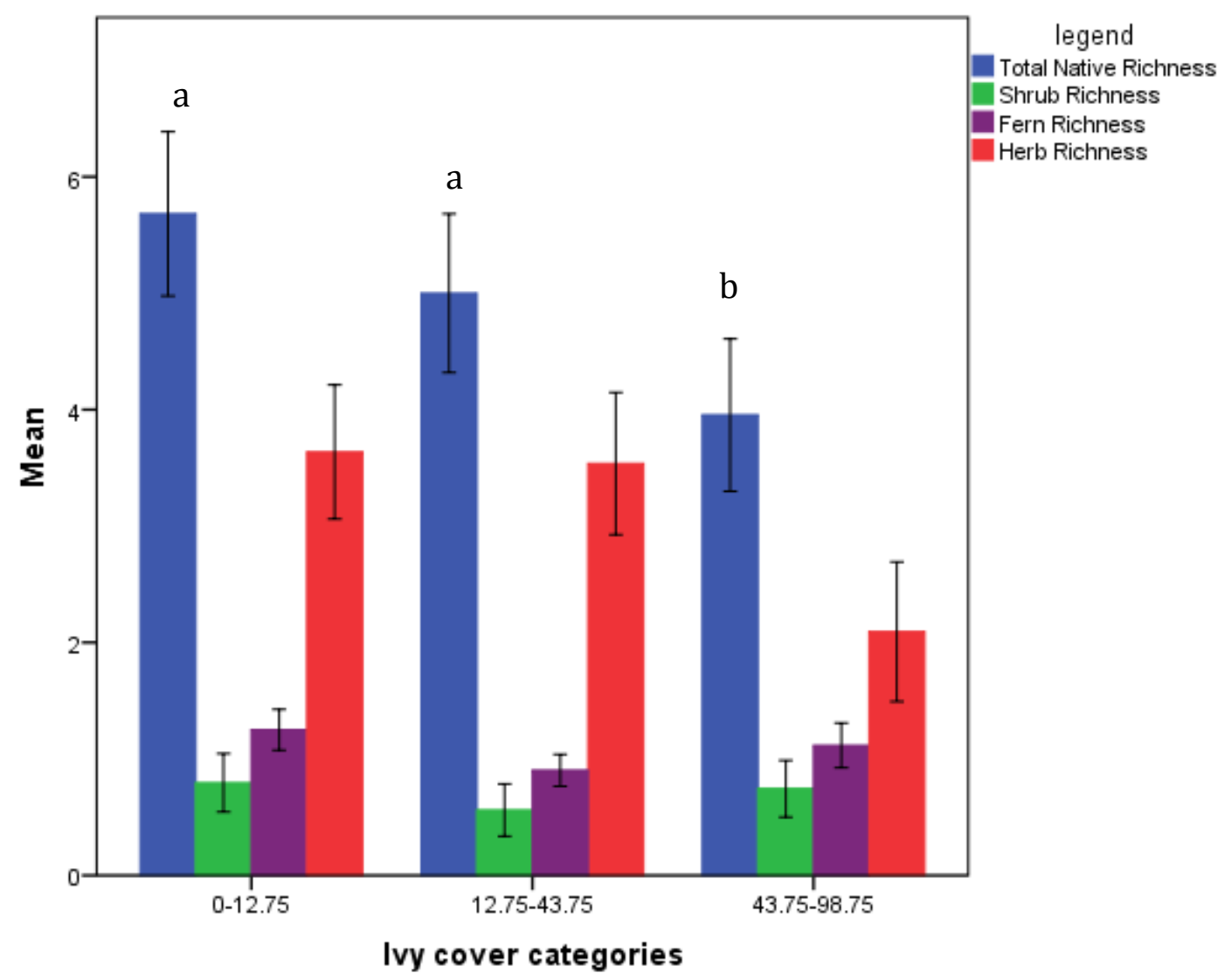

Error bars: $95 \% \mathrm{Cl}$

Figure 7: Mean total native understory richness across the three ivy cover categories: low (0-12.75), medium (12.75-43.75), and high (43.75-98.75). Richness was broken down by understory functional group, blue represents total richness, green represents shrub richness, purple represents fern richness, and red represents herb richness. A Kruskal Wallis nonparametric ANOVA showed that richness was significantly lower in high ivy plots compared to low ivy plots. The decreases in total richness decreases across the ivy cover categories in primarily explained by a decrease in herb richness. Error bars represent 95\% confidence interval. Different lowercase letters indicate significant difference between groups $(\mathrm{P}<0.05)$. 
Hypothesis 2b-As ivy cover increases then native understory community composition will significantly shift as seen by a reduction in cover and relative abundance of the native understory herbs, shrubs, and ferns:

As a functional group, both herbs and shrubs revealed a weak but significant and negative relationship with English ivy cover (0-97.5\%). Results from OLS regression suggest that as English ivy cover increases both herb cover $\left(F=9.412, P=0.002, R^{2}=0.07\right)$ and shrub cover $\left(\mathrm{F}=5.00, \mathrm{P}=0.027, \mathrm{R}^{2}=0.04\right)$ significantly decrease (Table 3$)$. The percent cover of herbs and shrubs varied across the three ivy cover categories (ANOVA; $\mathrm{F}_{\text {herb }}=9.15, \mathrm{P}_{\text {herb }}<0.001 \mathrm{~F}_{\text {shrub }}=3.21, \mathrm{P}_{\text {shrub }}=0.043$; Table 2, Figure 8). Plots containing high cover of English ivy also contained significantly less native herb cover $(\mathrm{F}=9.15$, $\mathrm{P}<0.001)$. Native herb cover was the greatest in medium cover plots $(\bar{x}=1.09 \% \pm 0.119 \%)$ and was the lowest in high ivy cover plots $(\bar{x}=0.54 \% \pm 0.088 \%)$. A different pattern was found for shrub cover, an ANOVA found that the greatest shrub cover occurred in plots that contained low ivy cover $(\bar{x}=1.59 \% \pm 0.321 \%)$ and significantly decreased in plots with medium ivy cover $(\bar{x}=0.61 \pm 0.18 \% ; \mathrm{F}=3.21, \mathrm{P}=0.043)$. Finally, although fern cover was the greatest in low ivy plots $(\bar{x}=8.4 \% \pm 0.814 \%)$ and lowest in the high ivy plots $(\bar{x}=3.9 \% \pm 0.648 \%)$ there were no significant patterns of fern cover reduction across all the three ivy categories $(\mathrm{F}=1.40, \mathrm{P}>0.05)$. 
Table 3: OLS regression and a paired ANOVA examining the relationship between native herb, shrub, and fern cover across the gradient (0-97.5\%) of English ivy cover. With increasing densities of ivy cover, herb and shrub cover will decrease while ferns show no response.

\begin{tabular}{|c|c|c|r|r|r|}
\hline $\begin{array}{c}\text { Independent } \\
\text { Variable }\end{array}$ & $\begin{array}{c}\text { Dependent } \\
\text { Variable }\end{array}$ & $\begin{array}{c}\text { Parameter } \\
\text { estimate }\end{array}$ & P-value & Model r2 & \multicolumn{1}{c|}{$\begin{array}{c}\text { Model F } \\
\text { stat }\end{array}$} \\
\hline \multirow{2}{*}{$\begin{array}{c}\text { English ivy } \\
\text { cover }\end{array}$} & $\begin{array}{c}\text { Herb cover } \\
\text { Shrub }\end{array}$ & -0.0339 & 0.0026 & 0.06951 & 9.412 \\
& Cover & -0.422 & 0.027 & 0.03822 & 5.007 \\
\hdashline & Fern Cover & -0.045 & 0.0813 & 0.02392 & 3.087 \\
\cline { 2 - 6 }
\end{tabular}




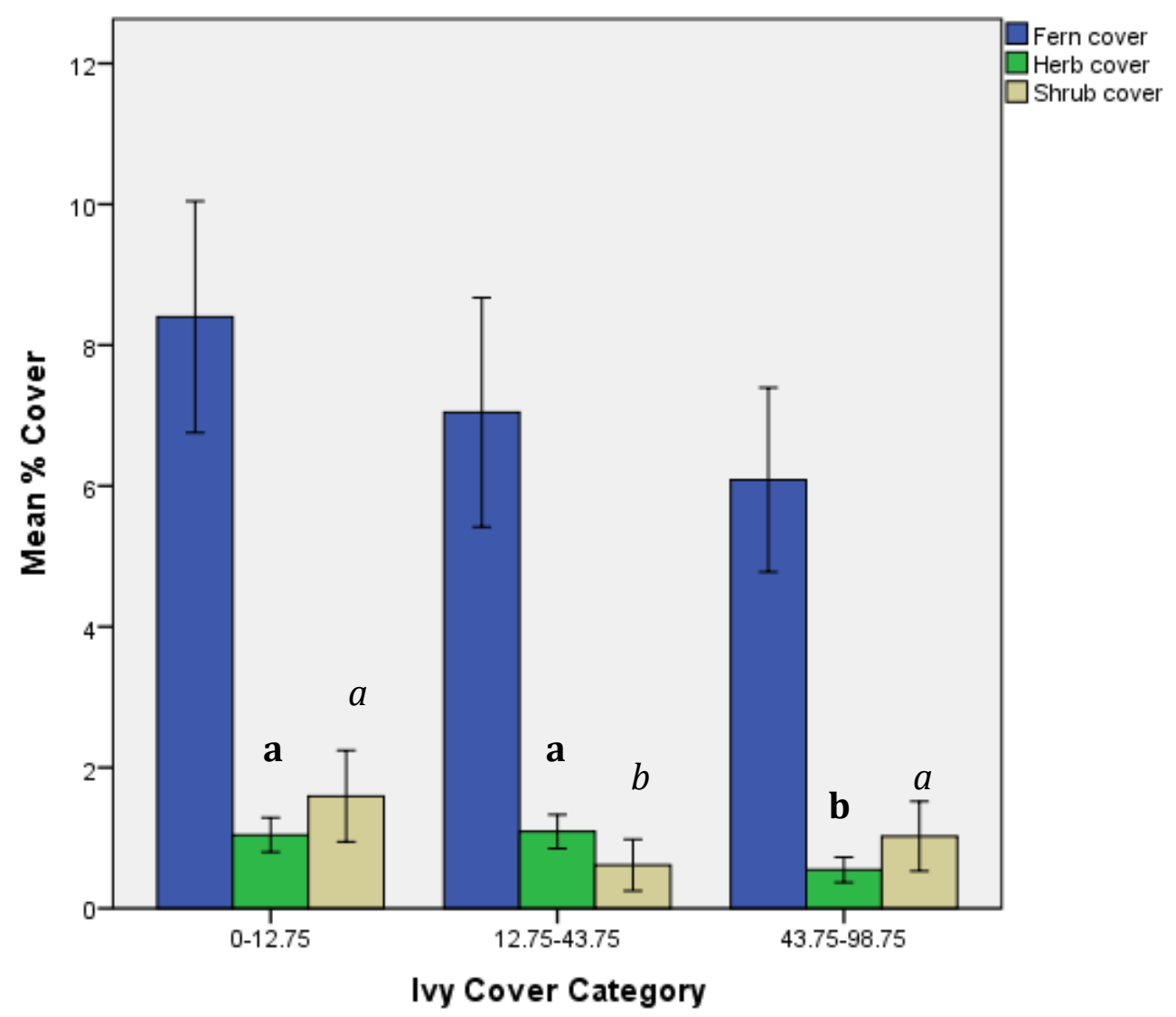

Error bars: $95 \% \mathrm{Cl}$

Figure 8: Mean cover of native functional groups (fern and allies, herb, and shrub) across the three ivy cover categories: low (0-12.75), medium (12.75-43.75), and high (43.7598.75). Multiple ANOVAs showed that herb cover is significantly lower in high ivy plots compared to medium and low, whereas shrub cover was lower in medium ivy plot compared to low and ivy. Different lowercase letters within functional groups indicate significant a difference between cover categories $(\mathrm{P}<0.05)$. Italicized letters show changes in shrub cover, and bold letters show changes in herb cover. Error bars represent $95 \%$ confidence interval. 
Individual native species varied in both cover and relative abundance across the three ivy cover categories (Table 3, Table 4). Of the fern species, mean cover and relative abundance of P. munitum, decreased with English ivy cover (Cover: $\chi^{2}=7.46$, Cover: $\mathrm{P}=0.02$, RA: $\chi^{2}=18.25$, RA: $\mathrm{P}=0.0001$; Table 4, Table 5) while mean cover and relative abundance of $A$. filix-femina was the highest in high ivy plots and significantly lower in medium ivy plots (Cover: $\chi^{2}=7.466$, Cover: $\mathrm{P}=0.023$, RA: $\chi^{2}=6.89$, RA: $\mathrm{P}=0.0 .031$ ). A Kruskal Wallis ANOVA found that cover and relative abundance of some common native herbs including Disporum hookeri (Cover: $\chi^{2}=6.38$, Cover: $\mathrm{P}=0.041$, RA: $\chi^{2}=7.6$, RA: $\mathrm{P}=0.022$ ), Galium trifolium (Cover: $\chi^{2}=8.65$, Cover: $\mathrm{P}=0.013$, RA: $\chi^{2}=$ 9.2, RA: $\mathrm{P}=0.01$ ), Achlys triphylla (Cover: $\chi^{2}=10.12$, Cover: $\mathrm{P}=0.006, \mathrm{RA}: \chi^{2}=10.28$, RA: $\mathrm{P}=0.0058$ ), and Viola glabella (Cover: $\chi^{2}=7.81$, Cover: $\mathrm{P}=0.02$, RA: $\chi^{2}=8.04$, RA: $\mathrm{P}=0.017$ ) were significantly reduced in high ivy plots (Table 4 , Table 5, Figure 9). The paired Kruskal multiple comparison test, on the other hand, did not find significant changes in these species across the ivy cover categories. The cover of H. tenuipes did not change across the ivy cover categories, but the relative abundance significantly decreased from high ivy plots to low ivy plots (Cover: $\chi^{2}=3.65$, Cover: $P=0.16$, RA: $\chi^{2}: 7.43$, RA: $\mathrm{P}=0.024)$. The dominant native shrub, $M$. nervosa, had significantly lower cover and relative abundance in medium and high ivy plots compared to low ivy plots (Cover: $\chi 2=$ 12.1, Cover: $\mathrm{P}=0.002, \mathrm{RA}: \chi^{2}=13.47$, RA: $\mathrm{P}=0.001$; Figure 9). Of the nonnative species, excluding Hedera spp., the herb Geranium robertianum had the highest cover and relative abundance in medium ivy plots and the lowest in high ivy plots (Cover: $\chi 2=$ 7.76, Cover: $\mathrm{P}=0.002, \mathrm{RA}: \chi^{2}=7.92$, RA: $\mathrm{P}=0.019$ ). 
Within each category of ivy cover (low, medium, and high) the relative abundances of the understory community changed. Out of the 25 common native understory species, fifteen had the highest mean relative abundance in low ivy plots; 8 had the highest mean relative abundance in medium ivy plots; and 2 had the highest mean relative abundance in high ivy plots (Table 5). Out of the 17 most common herb species, 12 species had the highest relative abundances in low ivy plots, four species had the highest relative abundance in medium ivy plots, and no species had the highest relative abundance in high ivy plots. Out of the three common fern species, one species was common in each of the three ivy cover categories. Finally, out of the six shrub species, four had the highest relative abundance in low ivy plots, three in medium ivy plots, and two in low ivy plots.

Finally, indicator species analysis using the product of the relative frequency and relative abundance values within each ivy cover group showed that $A$. triphylla, $A$. caudatum, M. nervosa, and P. munitum are significant predictors of low ivy cover. There were no predictors of high ivy cover, except English ivy, and there are no statistically significant predictors for medium cover categories (Table 5). 

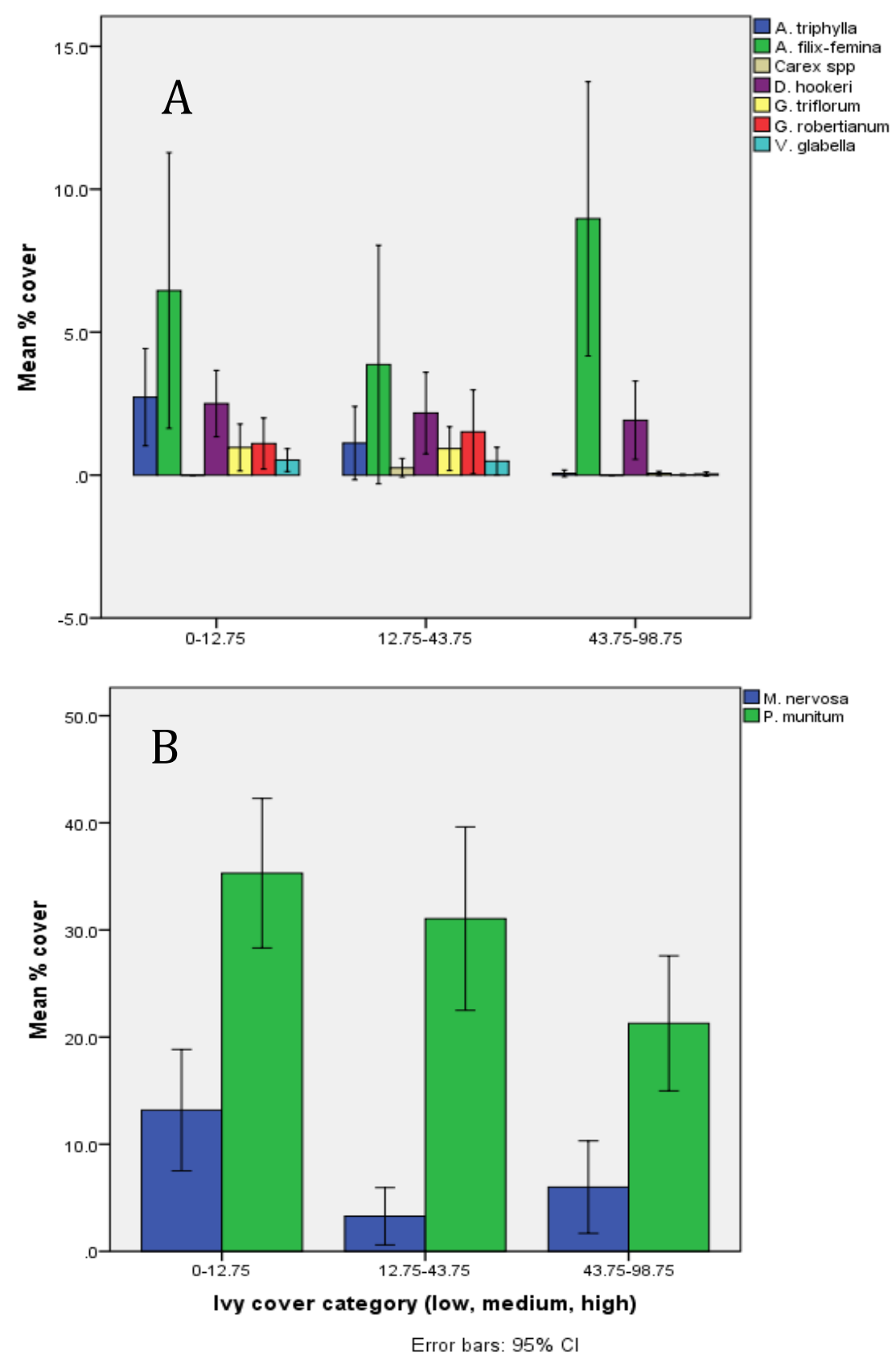

Figure 9: Mean percent cover of the understory species that significantly changed ( $>0.05$; Table 4) across low (0-12.75\%), medium (12.75-43.75\%), and high (43.7598.75\%) ivy cover categories. A) Kruskal Wallis ANOVA showed a reduction in mean cover for A. triphylla, Carex spp., D. hookeri, G. triflorum, V. glabella, while A. filixfemina showed higher cover in high ivy plots. $B$ ) Kruskal Wallis ANOVA and multiple comparison tests showed a reduction in P. munitum and M. nervosa across the ivy cover categories. Error bars represent $95 \%$ confidence interval. 
Table 4: Kruskal Wallis nonparametric ANOVA and Kruskal comparison test for each of the common understory species across low (0-12.75\%), medium (12.75-43.75\%), and high (43.75-98.75\%) ivy cover categories. Native understory species responded differently to the three densities of ivy cover. The cover of most species did not change across the ivy densities. Seven species showed lower cover in high ivy plots while two species showed higher cover in high ivy plots. Significant understory predictors of community composition were established by fitting a species vector on a non-metric multidimensional scaling plot. Asterisks or different lowercase letters represent significant differences between plots $(\mathrm{P}<0.05)$. Bold represents species that significantly changed across the three ivy cover categories.

\begin{tabular}{|c|c|c|c|c|c|c|c|c|c|}
\hline \multirow[t]{2}{*}{ Species } & \multirow{2}{*}{$\begin{array}{c}\text { Average/ivy } \\
0-12.75\end{array}$} & \multirow{2}{*}{$\begin{array}{l}\text { Average/ivy } \\
12.75-43.75\end{array}$} & \multirow{2}{*}{$\begin{array}{l}\text { Average/ivy } \\
43.75-98.75\end{array}$} & \multirow{2}{*}{$\begin{array}{l}\text { Kruskal } \\
\text { wallis } \\
\text { pvalue }\end{array}$} & \multirow[t]{2}{*}{ df } & \multirow[t]{2}{*}{ chisquared } & \multicolumn{3}{|c|}{$\begin{array}{l}\text { Kruskal Multiple comparison test; different } \\
\text { small letters or asterisk represent significant } \\
\text { difference }(P<0.05)\end{array}$} \\
\hline & & & & & & & Low & Medium & High \\
\hline \multicolumn{10}{|l|}{ Herb } \\
\hline Achlys triphylla & 2.72 & 1.122 & 0.058 & 0.00633 & 2 & 10.1248 & & & \\
\hline Adenocalulon bicolor & 0.045 & 0.036 & 0 & 0.353 & 2 & 2.078 & & & \\
\hline Asarum caudatum & 1.625 & 0.5366 & 0.186 & 0.068 & 2 & 5.3665 & & & \\
\hline Carex. spp & 0 & 0.256 & 0 & 0.039 & 2 & 6.47 & & & \\
\hline Circaea alpina & 0.068 & 0.073 & 0.04651 & 0.9307 & 2 & 0.1437 & & & \\
\hline Claytonia sibirica & 0.8182 & 2.476 & 0.1744 & 0.387 & 2 & 1.898 & & & \\
\hline Disporum hookeri & 2.5 & 2.171 & 1.19 & 0.04116 & 2 & 6.38 & & & \\
\hline Galium triflorum & 0.9659 & 0.9268 & 0.058 & 0.013 & 2 & 8.6536 & & & \\
\hline Hydrophyllum tenuipes & 10.36 & 10.12 & 8.035 & 0.1608 & 2 & 3.65 & & & \\
\hline Osmorhiza chilensis & 0.091 & 0.658 & 0.046 & 0.264 & 2 & 2.657 & & & \\
\hline Smilacina stellata & 0.4545 & 0.2683 & 0.6163 & 0.7084 & 2 & 0.6895 & & & \\
\hline Streptopus amplexifolius & 0 & 0.3415 & 0.011 & 0.5889 & 2 & 1.0589 & & & \\
\hline Tolmiea menziesii & 0.238 & 1.439 & 0.9884 & 0.1985 & 2 & 3.2334 & & & \\
\hline Tiarella trifoliata & 0.625 & 1.4 & 0.151 & 0.995 & 2 & 0.0086 & & & \\
\hline Trientalis latifolia & 0.2273 & 0.1463 & 0 & 0.2235 & 2 & 2.9969 & & & \\
\hline Trillium ovatum & 0.3295 & 1.5 & 0.3953 & 0.3825 & 2 & 1.9218 & & & \\
\hline Vancouveria hexandra & 5.17 & 4.15 & 1.43 & 0.2746 & 2 & 2.5848 & & & \\
\hline Viola glabella & 0.5227 & 0.4878 & 0.034 & 0.02009 & 2 & 7.815 & & & \\
\hline \multicolumn{10}{|l|}{ Shrub } \\
\hline Mahonia nervosa & 13.18 & 3.28 & 5.98 & 0.0023 & 2 & 12.1 & a. & $b$ & \\
\hline Oemleria cerasiformis & 0.09 & 0.6585 & 0.4651 & 0.2647 & 2 & 2.65 & & & \\
\hline Rubus parviflorus & 0 & 1.341 & 0.465 & 0.21 & 2 & 3.119 & & & \\
\hline Rubus spectabilis & 0.204 & 0.182 & 0.651 & 0.216 & 2 & 3.061 & & & \\
\hline Rubus ursinus & 0.7955 & 0.5366 & 0.7907 & 0.9342 & 2 & 0.1361 & & & \\
\hline Sambucus racemosa & 0.136 & 0.012 & 0.465 & 0.566 & 2 & 1.137 & & & \\
\hline Fern & & & & & & & & L & 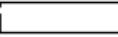 \\
\hline Athyrium filix-femina & 6.455 & 3.866 & 8.95 & 0.023 & 2 & 7.4667 & & & \\
\hline Polystichum munitum & 35.31 & 31.06 & 21.29 & 0.02391 & 2 & 7.467 & $a$ & 1ab & \\
\hline Pteridium aquillinum & 0.193 & 0.243 & 0.174 & 0.4977 & 2 & 1.395 & & & \\
\hline \multicolumn{10}{|l|}{ Nonnative } \\
\hline Clematis vitalba & 0.068 & 0.304 & 0.139 & 0.727 & 2. & 0.635 & & & \\
\hline Geranium robertianum & 1.1 & 1.512 & 0.011 & 0.0206 & 2 & 7.763 & & & \\
\hline Ilex aquifolium & 0.9659 & 1.28 & 1.221 & 0.5655 & 2 & 1.1402 & & & \\
\hline
\end{tabular}


Table 5: Table of relative abundance and significant $(\mathrm{P}<0.05)$ indicator species of common understory species across the three ivy cover categories: low (0-12.75), medium (12.75-43.75), and high (43.75-98.75). The relative abundance of understory species varied across the three ivy cover categories. Four species were significant indicators of low ivy cover plots, no species were indicators of medium ivy plots, and only one species was the indicator of high ivy plots. Bold indicates the ivy category where species has the highest relative abundance and species that significantly change across the ivy cover categories.

\begin{tabular}{|c|c|c|c|c|c|c|c|c|}
\hline & \multicolumn{3}{|c|}{ Mean Relative Abundance } & & \multirow[b]{2}{*}{ df } & \multirow[b]{2}{*}{ if } & \multirow[b]{2}{*}{ pvalue } & \multirow[b]{2}{*}{$\begin{array}{c}\text { Significant indicator species and } \\
\text { indicator value for each ivy cover } \\
\text { category }(\mathrm{P}<0.05)\end{array}$} \\
\hline $\begin{array}{c}\begin{array}{c}\text { Functional group and } \\
\text { species }\end{array} \\
\text { Herb } \\
\end{array}$ & $\begin{array}{c}0-12.75 \% \\
\text { Ivy }\end{array}$ & \begin{tabular}{|c|}
$\begin{array}{c}12.75-43.75 \% \\
\text { Ivy }\end{array}$ \\
\end{tabular} & $\begin{array}{c}43.75-98.75 \% \\
\text { Ivy }\end{array}$ & $\begin{array}{c}\text { KW test chi } \\
\text { square }\end{array}$ & & & & \\
\hline Achlys triphylla & 0.0267 & 0.00993 & 0.00034 & 10.28 & & 2 & 0.0058 & Low ivy indicator $(0.17)$ \\
\hline Asarum caudatum & $0.0152 \perp$ & $0.0046 \mathrm{i}$ & 0.0014 & 5.482 & & 2 & 0.0644 & Low ivy indicator $(0.14)$ \\
\hline Adenocalulon bicolor & 0.00085 & 0.0004 & -0 & 2.074 & & 2 & 0.354 & \\
\hline Carex spp. & $00^{\top}$ & 0.0035 & 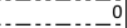 & 6.466 & & 2 & 0.0394 & \\
\hline Circaea alpina & 0.00096 & 0.00094 & 0.0002 & 0.2054 & & 2 & 0.9024 & \\
\hline Claytonia sibirica & 0.01035 & 0.0288 & 0.0012 & 2.129 & & 2 & 0.3447 & \\
\hline Disporum hookeri & 0.0265 & 0.0209 & 0.0122 & 7.6 & & 2 & 0.0223 & \\
\hline Galium triflorum & 0.0116 & 0.0115 & 0.003 & 9.206 & & 2 & 0.01 & \\
\hline Hydrophyllum tenuipes & $0 . \overline{1277}$ & $\overline{0} .1029$ & 0.0667 & 7.4362 & & 2 & 0.0242 & \\
\hline Osmorhiza chilensis & 0.00123 & 0.008 & 0.003 & 2.658 & & 2 & 0.264 & \\
\hline Smilacina stellata & 0.00525 & 0.00465 & 0.004 & 0.7364 & & 2 & 0.692 & \\
\hline Tiarella trifoliata & 0.00545 & $0.0132 \bar{T}$ & 0.001 & 0.0101 & & 2 & 0.995 & \\
\hline Tolmiea menziesii & 0.00201 & $0.011 \overline{3} 3$ & 0.007 & 3.2274 & & 2 & 0.1992 & \\
\hline Trientalis latifolia & 0.00191 & 0.0013 & $\underline{0}$ & 2.996 & & 2 & 0.2235 & \\
\hline Trillium ovatum & 0.003421 & 0.017 & 0.003 & 1.9889 & & 2 & 0.3699 & \\
\hline Vancouveria hexandra & 0.0485 & 0.0401 & 0.0103 & 3.0472 & & 2 & 0.2179 & \\
\hline Viola glabella & 0.00725 & $\overline{0} .0056$ & $0.000 \overline{2}$ & 8.041 & & 2 & 0.01794 & \\
\hline \multicolumn{9}{|l|}{ Fern } \\
\hline Athyrium filix-femina & 0.05972 & 0.0357 & 0.073 & 6.893 & & 2 & 0.03185 & \\
\hline Polystichum munitum & $0 . \overline{3905}$ & $\overline{0} .2939 \overline{1}$ & $0 . \overline{16} \overline{4}$ & 18.2575 & & 2 & 0.0001085 & Low ivy indicator $(0.37)$ \\
\hline Pteridium aquillinum & 0.00153 & 0.0019 & 0.00151 & 1.3954 & & 2 & 0.4977 & \\
\hline \multicolumn{9}{|l|}{ Shrub } \\
\hline Mahonia nervosa & 0.153 & 0.035 & 0.045 & 13.474 & & 2 & 0.001186 & Low ivy indicator (0.32) \\
\hline Oemleria cerasiformis & 0 & 0.0024 & 0.001 & 2.012 & & 2 & 0.3657 & \\
\hline Rubus parviflorus & $0_{1}^{+}$ & 0.0118 & 0.039 & 3.1192 & & 2 & 0.2102 & \\
\hline Rubus spectabilis & 0.00198 & $0.0017 \overline{1} \mathrm{j}$ & 0.0047 & 3.0126 & & 2 & 0.2217 & \\
\hline Rubus ursinus & 0.00753 & 0.0058 & 0.006 & 0.1653 & & 2 & 0.9207 & \\
\hline Sambucus racemosa & $0.00216 T$ & $<0.0001$ & $0.00 \overline{3}$ & 1.146 & & 2 & 0.538 & \\
\hline \multicolumn{9}{|l|}{ Nonnative spp. } \\
\hline Clematis vitalba & $0.001:$ & 0.0028 & 0.0011 & 0.6079 & & 2 & 0.7379 & \\
\hline Geranium robertianum & 0.01221 & $\overline{0} .017 \overline{5}$ & $<0.0001$ & 7.9247 & & 2 & 0.01902 & \\
\hline Ilex aquifolium & $0 . \overline{1671}$ & $0.12 \overline{17}$ & 0.012 & 0.984 & & 2 & 0.6114 & \\
\hline Hedera spp. & 0.0578 & $\overline{0} . \overline{2} 931 \dagger$ & $0 . \overline{57} \overline{3}$ & 105.531 & & 2 & $<0.00001$ & High Ivy Indicator $(0.69)$ \\
\hline
\end{tabular}


Hypothesis 2c: As ivy cover increases the native understory community composition will significantly shift as seen by changes in species dominance in a multidimensional space:

Understory community composition under conditions of low, medium, and high ivy cover displayed significant distinct clustering within the ordination (Figure 10). An ANOSIM (Analysis of Similarity) confirmed significant differences in understory community composition between the three ivy cover categories $(\mathrm{P}<0.001$; Figure 11$)$. A pair-wise comparison confirmed a significant difference between each cover category pairing $(\mathrm{P}<0.001$; Table 6$)$. Within the ordination, low ivy sites grouped on the lower right, the high ivy sites grouped on the upper left, and the medium ivy sites are scattered between the two groups in the ordination (Figure 9).

Vectors representing the variation in common herb species were overlaid in the NMDS ordination to identify which species are driving groupings within the ordination. Fourteen species, including ivy, significantly $(\mathrm{P}<0.05)$ contributed in defining site dissimilarity across our NMDS ordination (Figure 12). Of the 13 native species, ten were herb species, two are fern species, and one was a shrub species. The species that predominantly drove the distribution of sites, shown with the longest vectors, creating the most dissimilarity within the ordination space were: Hedera spp., P. munitum, M. nervosa, and H. tenuipes. The herbs, except for Tolmiea menziesii, were grouped between $H$. tenuipes and M. nervosa, clustering within the low ivy sites. The native shrub, M. nervosa predominately drove the distribution of low ivy cover sites, where English ivy drove the distribution of the high ivy cover sites. 
Bubble plots by functional group were generated to facilitate interpretation (Figure 13). Bubbles of increasing size represent increasing abundance. Native shrub cover, and to a minor extent herb and fern cover, likely drove the distribution for the low ivy cover sites. Abundance of both native and nonnative species likely drove the medium ivy cover sites, while predominately ivy, and to a minor extent fern cover, drove the distribution in the high ivy sites.

Out of the thirteen environmental variables measured, four environmental vectors were found to significant explain dissimilarity between sites. Soil moisture, litter depth, deciduous tree cover and conifer tree cover significantly explain differences in composition between sites $(\mathrm{P}<0.05$; Figure 14). The NMDS triplot with overlaid environmental vectors and the contour plots reveal similar patterns of influence on community composition (Figure 14, Figure 15). High ivy sites were characterized with high soil moisture and high deciduous canopy cover while low ivy sites were grouped in areas with high litter depth and high conifer cover. Medium ivy sites were grouped in areas where the dominant environmental drivers were measured near or at their relative mean. 


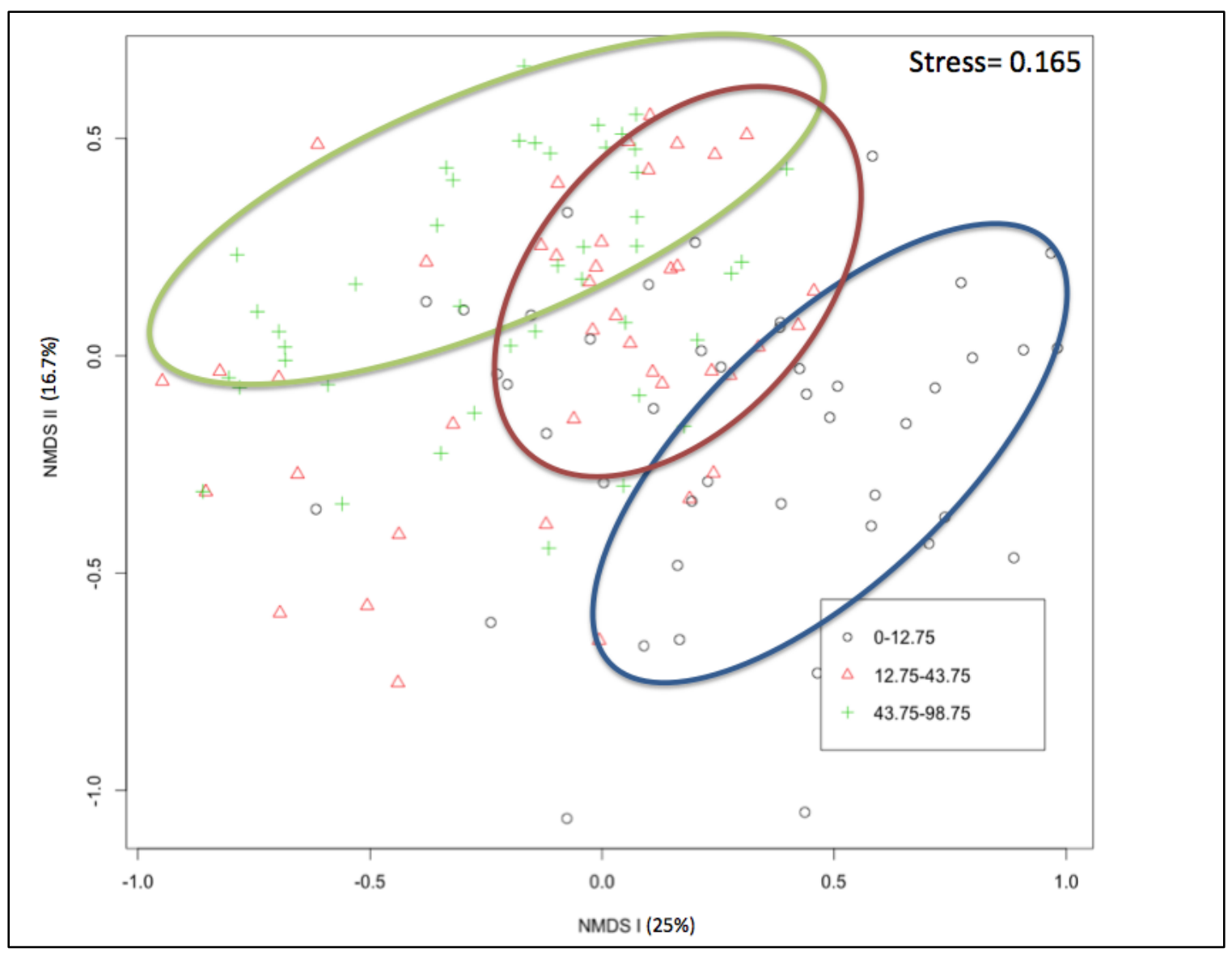

Figure 10: NMDS plot of survey sites grouped by low, medium and high Hedera spp. cover categories. The three Hedera spp. coverage categories: 0-12.75\% (black circles), $12.75-43.75 \%$ (red triangles), and 43.75-98.75\% (green plus) are delimited by color coordinated ovals. Ovals contain the majority of sites within a group, and emphasize plot location. The three dimensional plot stress is 0.165 . NMDS I represents $25 \%$ and NMDS II represents $16.7 \%$ of the total original Bray-Curtis dissimilarity matrix. 


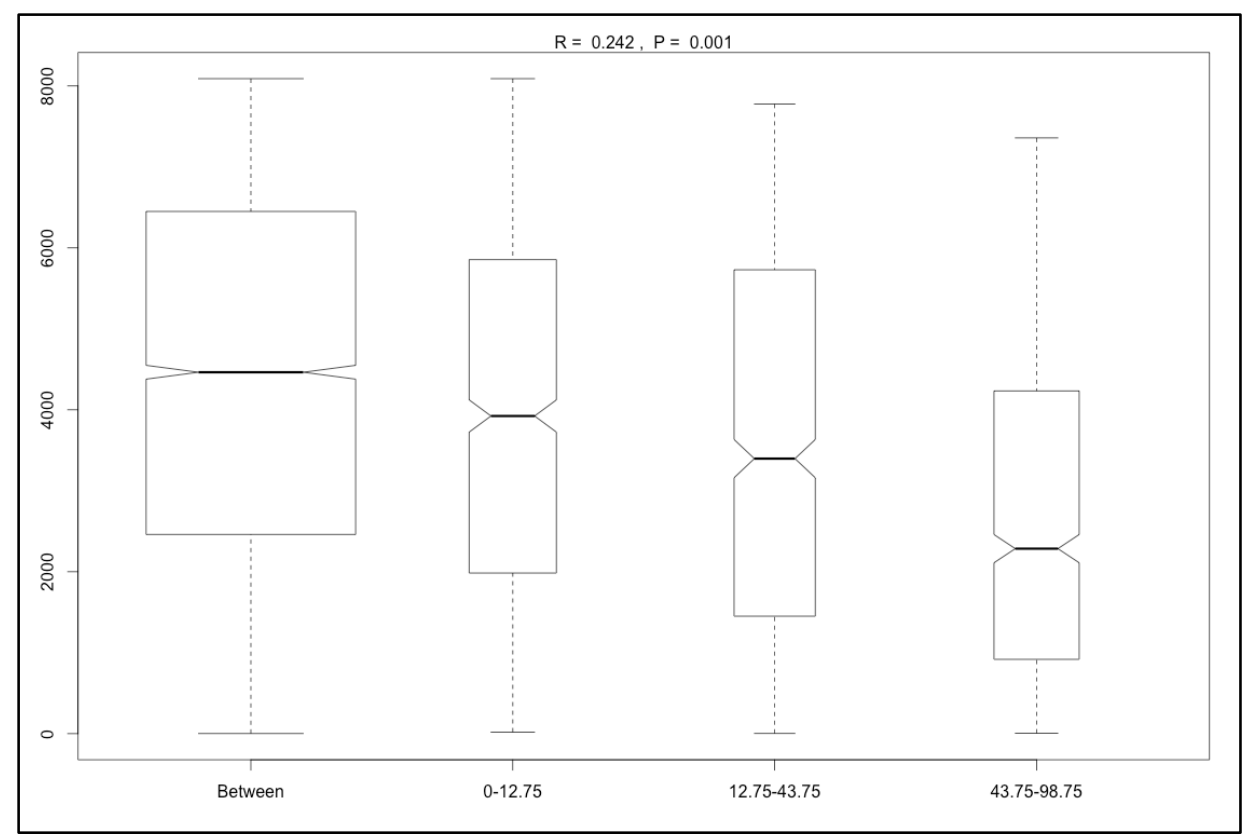

Figure 11: Boxplot of ANOSIM (Analysis of Similarity) Test showing a significant change in community composition between the percent ivy cover groupings and within each group. ANOSIM uses a bootstrap randomization using the Bray-Curtis dissimilarity measure with 999 permutations to determine the portability of group membership based on within-stand verse between stand variance within a community. Results are shown at top and significant $(\mathrm{R}=0.242, \mathrm{p}=0.001)$. 
Table 6: Pair-wise ANOSIM test showed a significant change in community composition between the three English ivy cover groups, low (0-12.75\%), medium (12.75-43.75\%), and high (43.75-98.75\%). * P-value with Bonferroni correction $(<0.0167)$.

\begin{tabular}{|c|c|c|}
\hline Pair-wise Test & R-Stat & P-Value * \\
\hline $\begin{array}{c}0-12.75 \text { vs. } 12.75- \\
13.75\end{array}$ & 0.207 & 0.001 \\
\hline $\begin{array}{c}12.75-43.75 \text { vs. 43.75- } \\
98.75\end{array}$ & 0.243 & 0.001 \\
\hline $\begin{array}{c}0-12.75 \text { vs } 43.75- \\
98.75\end{array}$ & 0.535 & 0.001 \\
\hline
\end{tabular}




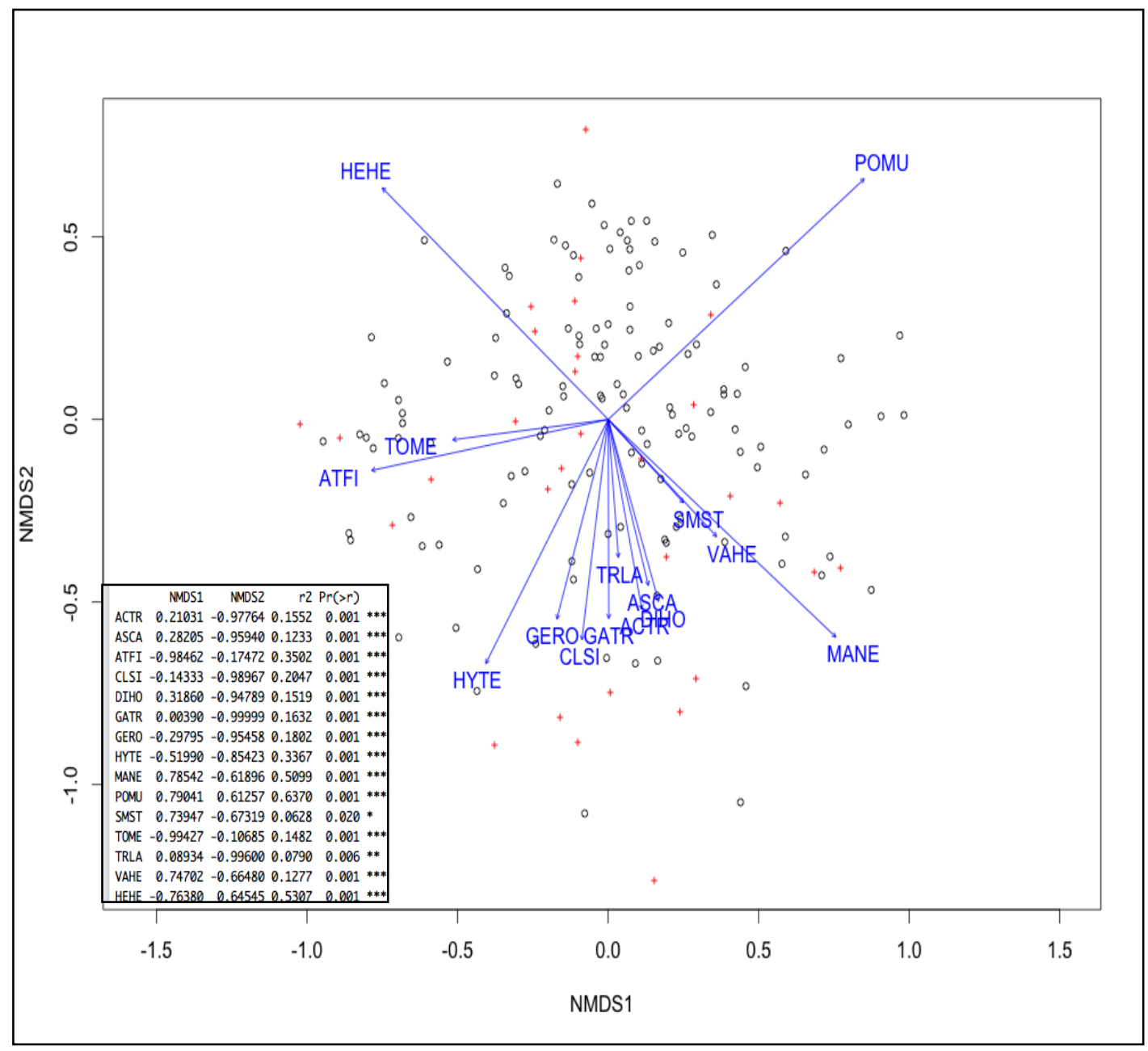

Figure 12: NMDS triplot of sampling sites (black circles) and plant species (red crosses). Plant species' vectors are superimposed (blue arrows) displaying the vector magnitude (length) and direction. Also displayed are the vector plant species coefficients for NMDS I and II. Species codes are used in this plot for clarity: Achlys triphylla(ACTR), Asarum caudatum(ASCA), Athyrium filix-femina (ATFI), Claytonia sibrica (CLSI), Disporum hookeri (DIHO), Galium triflorum (GATR), Geranium robertianum (GERO), Hydrophyllum tenuipes (HYTE), Mahonia nervosa (MANE), Polysticum munitum (POMU), Maianthemum stellatum (SMST), Trientalis borealis ssp. latifolia (TRLA), Tolmiea menziesii (TOME), Vancouveria hexandra (VAHE), Hedera spp. (HEHE). 


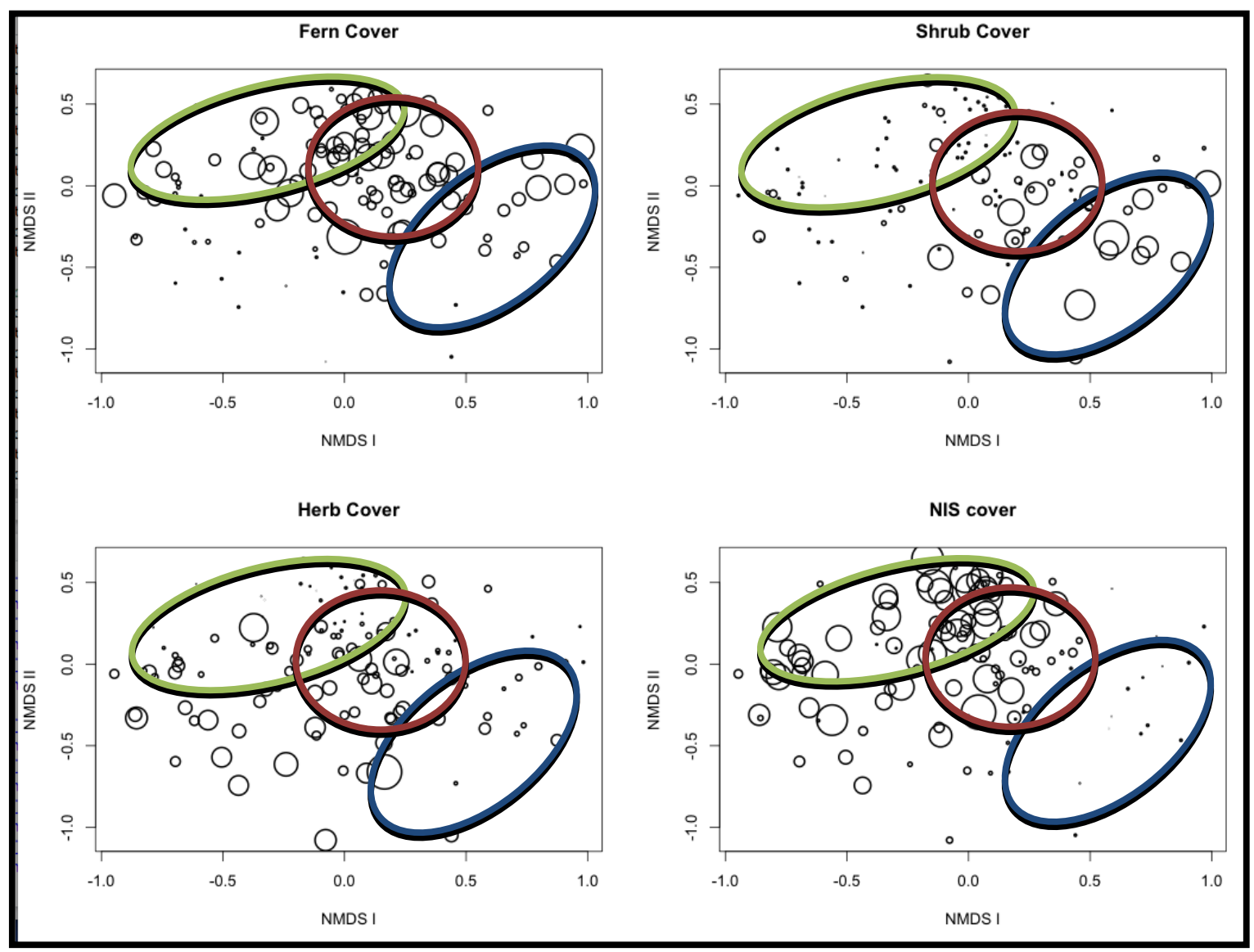

Figure 13: Bubble plots of the dominant functional groups in the forest understory community composition. NIS cover is primary a function of Hedera spp. cover. Clear clustering by functional group is evident, contributing to the separation of the sites within the ordination space. The ovals represent ivy cover categories, green is high ivy cover, red represents medium ivy cover, and blue represents low ivy cover. Bubbles of increasing size represent increasing abundance. 


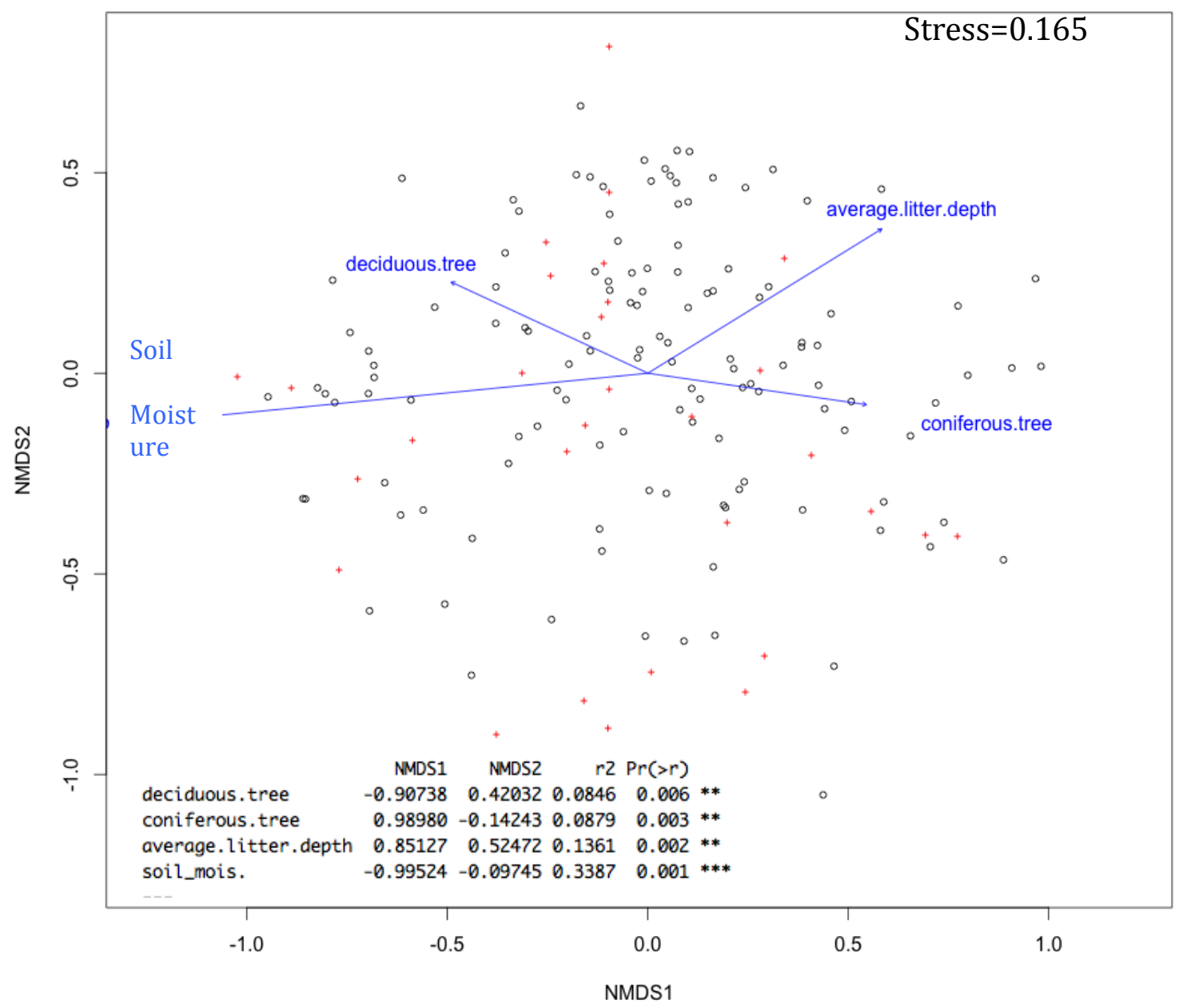

Figure 14: NMDS triplot of sample site (black circles) and species (red crosses) overlain with environmental variable vectors (blue arrows). Deciduous tree and conifer tree represent percent overstory canopy cover. Table of environmental variable coefficients is included at bottom left. Three dimensional plot stress is 0.165 . 

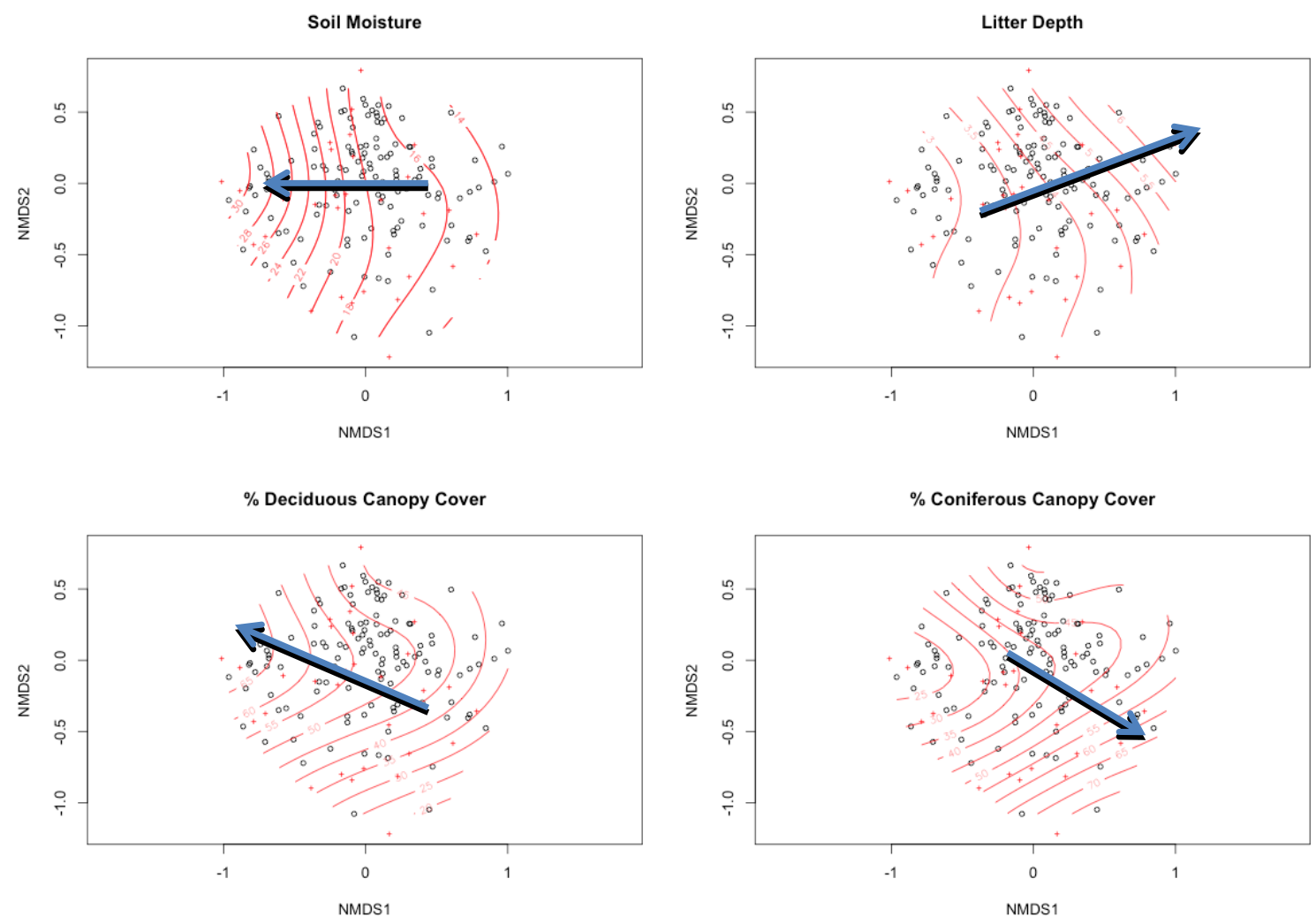

Figure 15: Contour plots of the four significant $(\mathrm{P}>0.05)$ environmental variables superimposed on NMDS ordination plot. Three dimensional plot stress is 0.165 . A blue arrow shows the increase in the environmental gradient. Soil moisture and deciduous canopy cover explain high ivy cover sites while litter depth and conifer canopy cover explain low ivy cover sites. 
Hypothesis 3-Areas with a high density of ivy cover will have lower soil moisture compared to areas with low ivy density:

Soil moisture as measured by volumetric water content (VWC) significantly (ANOVA; $\mathrm{F}=3.599, \mathrm{P}=0.03$ ) increased from $17.26 \% \pm 0.655 \%$ in low ivy plots to $21.33 \% \pm 1.26 \%$ in high ivy plots (Figure 16). A multiple linear regression showed that VWC of the soil was significantly correlated with English ivy cover, litter depth, slope, and overstory conifer cover $\left(r^{2}=0.521, \mathrm{P}<0.001\right.$; Table 8 , Figure 14$)$. English ivy was positively correlated to VWC while slope, litter depth, and conifer cover had a significant negative correlation. Linear models show that other variables- total native understory cover, aspect, total canopy cover, deciduous overstory cover; which we thought would be associated with VWC, did not significantly correlate with changes in soil moisture. 


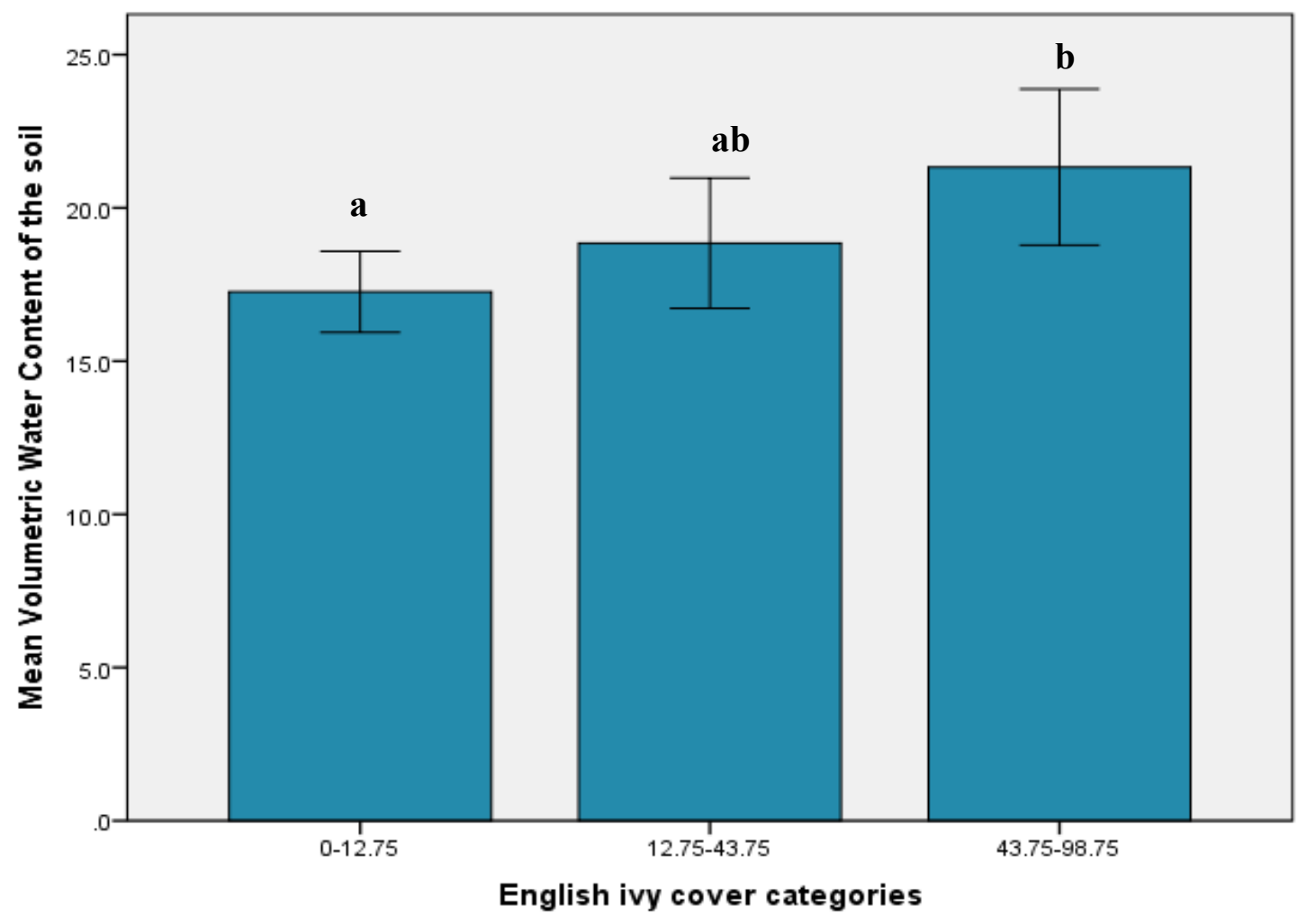

Error bars: $95 \% \mathrm{Cl}$

Figure 16: Mean VWC of the soil across the three ivy cover categories: low (0-12.75), medium (12.75-43.75), and high (43.75-98.75). VWC significantly $(\mathrm{P}=0.03, \mathrm{~F}=3.599)$ increased from low ivy cover to high ivy cover. Error bars represent $95 \%$ confidence interval. Different lowercase letters indicate significant difference $(\mathrm{P}<0.05)$. 
Table 7: Multiple linear regression of the predictors of the VWC of the soil. There is a significant relationship between VWC and English ivy cover, litter depth, slope, and overstory conifer cover.

\begin{tabular}{|c|c|c|c|c|c|c}
\hline $\begin{array}{c}\text { Dependent } \\
\text { variable }\end{array}$ & $\begin{array}{c}\text { Independent } \\
\text { Variable }\end{array}$ & $\begin{array}{c}\text { Parameter } \\
\text { estimate }\end{array}$ & P-value & Model r2 & $\begin{array}{c}\text { Model P- } \\
\text { value }\end{array}$ & Model F stat \\
\hline $\begin{array}{c}\text { Soil moisture } \\
\text { (VWC) }\end{array}$ & $\begin{array}{c}\text { English ivy } \\
\text { cover }\end{array}$ & 0.022 & $<0.001$ & 0.5213 & $<0.001$ & 33.49 \\
\hline $\begin{array}{c}\text { Litter depth } \\
\text { Slope }\end{array}$ & -0.2541 & -0.0436 & 0.001 & 0.008 & & \\
\hdashline $\begin{array}{c}\text { Conifer } \\
\text { overstory } \\
\text { cover }\end{array}$ & -0.0407 & $<0.001$ & & & \\
& & & & &
\end{tabular}



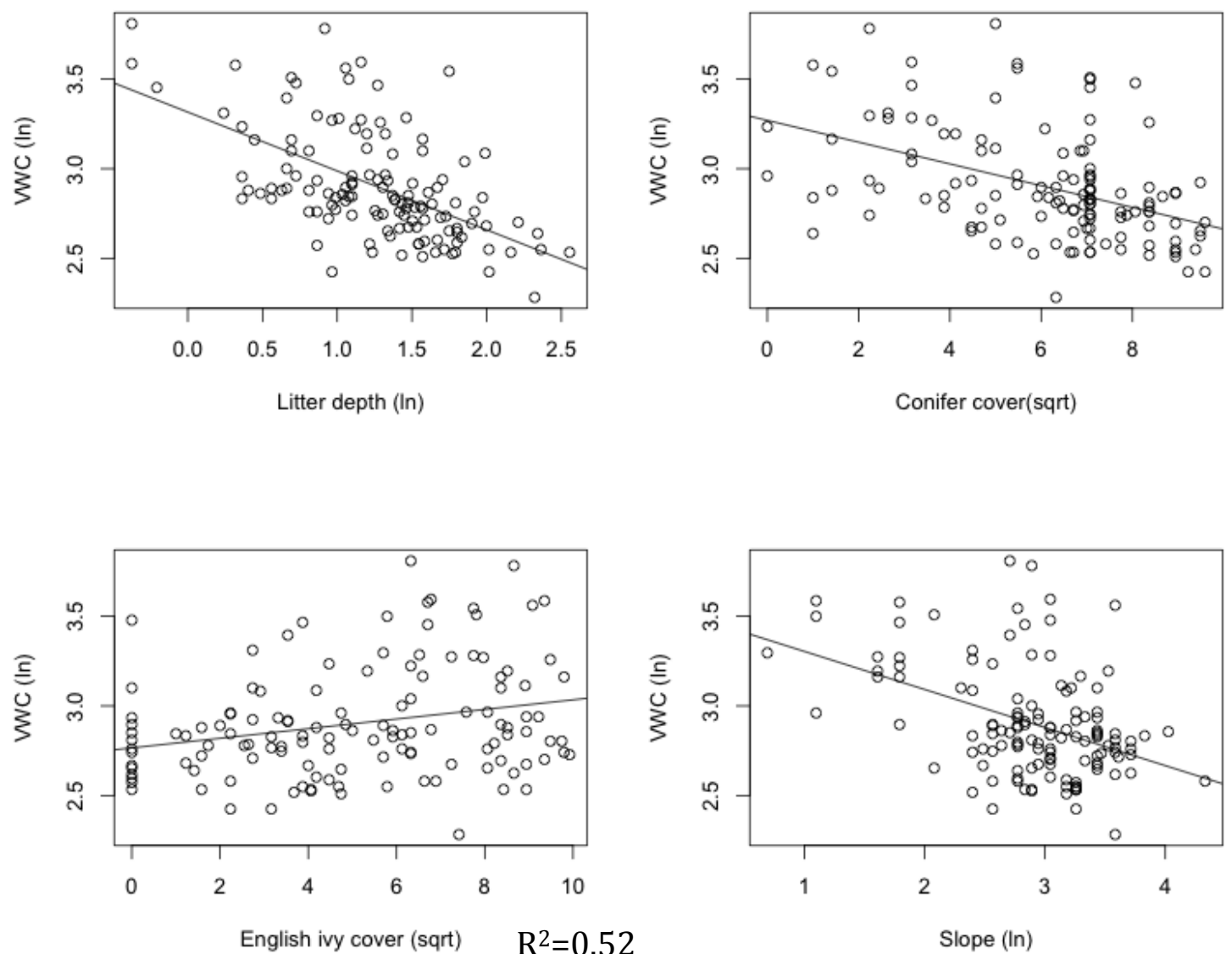

$\hat{\mathrm{Y}}=0.022 \mathrm{X}_{\text {English ivy }}+-0.254 \mathrm{X}_{\text {litterdepth }}+-0.0436 \mathrm{X}_{\text {slope }}+-0.040 \mathrm{X}_{\text {conifercover }}+3.54$

Figure 17: Volumetric water content (VWC) of the soil as a function of log transformed slope, square root transformed conifer cover, log transformed litter depth, and square root transformed English ivy cover. The multiple linear regression showed that slope, ivy cover, conifer canopy cover, and litter depth significantly $(\mathrm{R} 2=0.52, \mathrm{~F}=33.49, \mathrm{P}<0.001)$ explains the variability in VWC across the community. 
Hypothesis 4- Under low water availability, common throughout the summer months, a) English ivy will have high stomatal conductance and less negative water potential, and b) native co-occurring herbs, Vancouveria hexandra and Hydrophyllum tenuipes, will have low stomatal conductance and more negative water potential.

Summary:

Across the three summer sampling periods, the co-occurring herbs and the measured environmental variables are significantly changing, yet the water relations of ivy remains constant. Water was significantly more available to the native herbs both predawn and midday in late summer compared to early summer. The conductance of both native herbs was the highest in early summer compared to late summer. Site conditions:

Twenty-two species were found in the 15 water status plots, consisting of 13 native herbs, three ferns, three native shrubs, three nonnative shrubs and vines. Mean English ivy cover was $40.7 \% \pm 7.58 \%$, mean native herb cover was $9.40 \%$, mean native shrub cover was $4.68 \%$, and mean fern cover was $2.8 \%$ across the 15 sites. Mean canopy cover of the mixed conifer and deciduous overstory community was $68.78 \% \pm 2.97 \%$. Environmental Conditions:

Vapor pressure deficit (VPD) changed across the summer season and throughout the day (Table 9). Mean VPD was consistently higher during midday sampling compared to predawn sampling. During both the predawn and midday sampling, VPD was the lowest late summer and then highest early summer (Table 10). 
Throughout the three summer months of measurement the volumetric water (VWC) content of the soil significantly changed $(\mathrm{F}=14.91, \mathrm{P}<0.001)$. Mid-summer soil moisture $(12.2 \% \pm 0.83)$ was significantly lower than both early summer $(19.3 \% \pm 1.07)$ and late summer $(18.4 \% \pm 1.2)(\mathrm{F}=14.915, \mathrm{P}<0.001 ;$ Table 11). Predawn water potential $\left(\psi_{\mathrm{pd}}\right)$ measurements indicate that available soil water varied for each species throughout the season (Table 11; Figure 19). Water availability for both $H$. tenuipes $\left(\Psi_{\mathrm{pd}}\right)$ and $V$. hexandra $\left(\Psi_{\mathrm{pd}}\right)$ significantly increased throughout the season and was more readily available in the late summer compared to early summer $\left(\mathrm{F}_{H \text {. tenuipes }}=15.88, F_{V \text {. hexandra }}=5.24\right.$ $\mathrm{P}<0.001)$. 2013 had unusual seasonal precipitation patterns of early and late summer rains, (Figure 18) which departed from normal precipitation in September of 2013 (Table 8). English ivy $\Psi_{\mathrm{pd}}$ showed no significant change throughout the season, suggesting that water was more readily available for English ivy compared to co-occurring native herbs due to physiological differences $(\mathrm{F}=2.73, \mathrm{p}>0.05)$.

Seasonal changes in water status:

Although available soil water $\left(\mathrm{F}_{H . \text { tenuipes }}=15.88, F_{V \text {. hexandra }}=5.24 \mathrm{P}<0.001\right)$ varied across the sampling periods for the native herbs, with less water available mid-summer compared to early and late summer, for ivy there was no significant response in stomatal conductance $(\mathrm{F}=0.605, \mathrm{P}=0.55)$ and midday water potential $(\mathrm{F}=2.151, \mathrm{P}=0.128)$. Overall, mean $\mathrm{g}_{\mathrm{s}}, \Psi_{\mathrm{pd}}$, and $\Psi_{\mathrm{md}}$ of English ivy did not significantly change during the summer $(\mathrm{P}>0.05$; Table 11, Figure 19, Figure 20, Figure 21). Mean stomatal conductance $\left(\mathrm{g}_{\mathrm{s}}\right)$ of $H$. tenuipes varied across the sampling periods. The conductance of H. tenuipes was the highest in early summer $\left(163.2 \pm 9.71 \mathrm{mmol} \mathrm{m}^{-2} \mathrm{~s}^{-1}\right)$ and significantly 
decreased $(\mathrm{F}=24.214, \mathrm{P}<0.001)$ throughout the season (Table 11, Figure 20). The mean $\mathrm{g}_{\mathrm{s}}$ for $H$. tenuipes was more variable in the late summer (mean=64.1 $\pm 10.39 \mathrm{mmol} \mathrm{m}^{-2} \mathrm{~s}^{-1}$ ) compared to early summer (mean=163.2 $\left.\pm 9.71 \mathrm{mmol} \mathrm{m}^{-2} \mathrm{~s}^{-1}\right)$.

While early summer and late summer had statistically the same average soil VWC, soil water was significantly more available both predawn $\left(\Psi_{\mathrm{pd}}\right)$ and midday $\left(\Psi_{\mathrm{md}}\right)$ for both $H$. tenuipes and $V$. hexandra in late summer compared to early summer $\left(\mathrm{F}_{H}\right.$. tenuipes $=11.017, F_{V . \text { hexandra }}=8.303, \mathrm{P}<0.001$; Table 11 Figure 19, Figure 21). Mean $\mathrm{g}_{\mathrm{s}}$ of $V$. hexandra was the highest in early summer $\left(92.4 \pm 6.42 \mathrm{mmol} \mathrm{m}^{-2} \mathrm{~s}^{-1}\right)$ and significantly decreased $(\mathrm{F}=24.214, \mathrm{P}<0.001)$ as the summer progressed (Table 11; Figure 20). Mean stomatal conductance of $H$. tenuipes decreased the greatest compared to both other species between early summer and late summer, decreasing $98.2 \mathrm{mmol} \mathrm{m}^{-2} \mathrm{~s}^{-1}$ while V. hexandra decreased $44.4 \mathrm{mmol} \mathrm{m}^{-2} \mathrm{~s}^{-1}$ and English ivy only decreased $4.6 \mathrm{mmol} \mathrm{m}$ ${ }^{2} \mathrm{~s}^{-1}$. English ivy had consistently less negative and less variable mean midday water potential across seasons compared to both native herb species (Table 11). Late summer, when soil water was typically most available to all species, $\mathrm{g}_{\mathrm{s}}$ across species was similar ranging from 48.1- $66.6 \mathrm{mmol} \mathrm{m}^{-2} \mathrm{~s}^{-1}$. In early summer, when soil water was more limiting to the native herbs, $\mathrm{g}_{\mathrm{s}}$ varied across species, consisting of $H$. tenuipes with the highest conductance (163.2 $\mathrm{mmol} \mathrm{m}^{-2} \mathrm{~s}^{-1}$ ), English ivy with the lowest conductance $\left(69.5 \mathrm{mmol} \mathrm{m}^{-2} \mathrm{~s}^{-1}\right)$, and $V$. hexandra falling the middle (92.4 mmol $\left.\mathrm{m}^{-2} \mathrm{~s}^{-1}\right)$ 


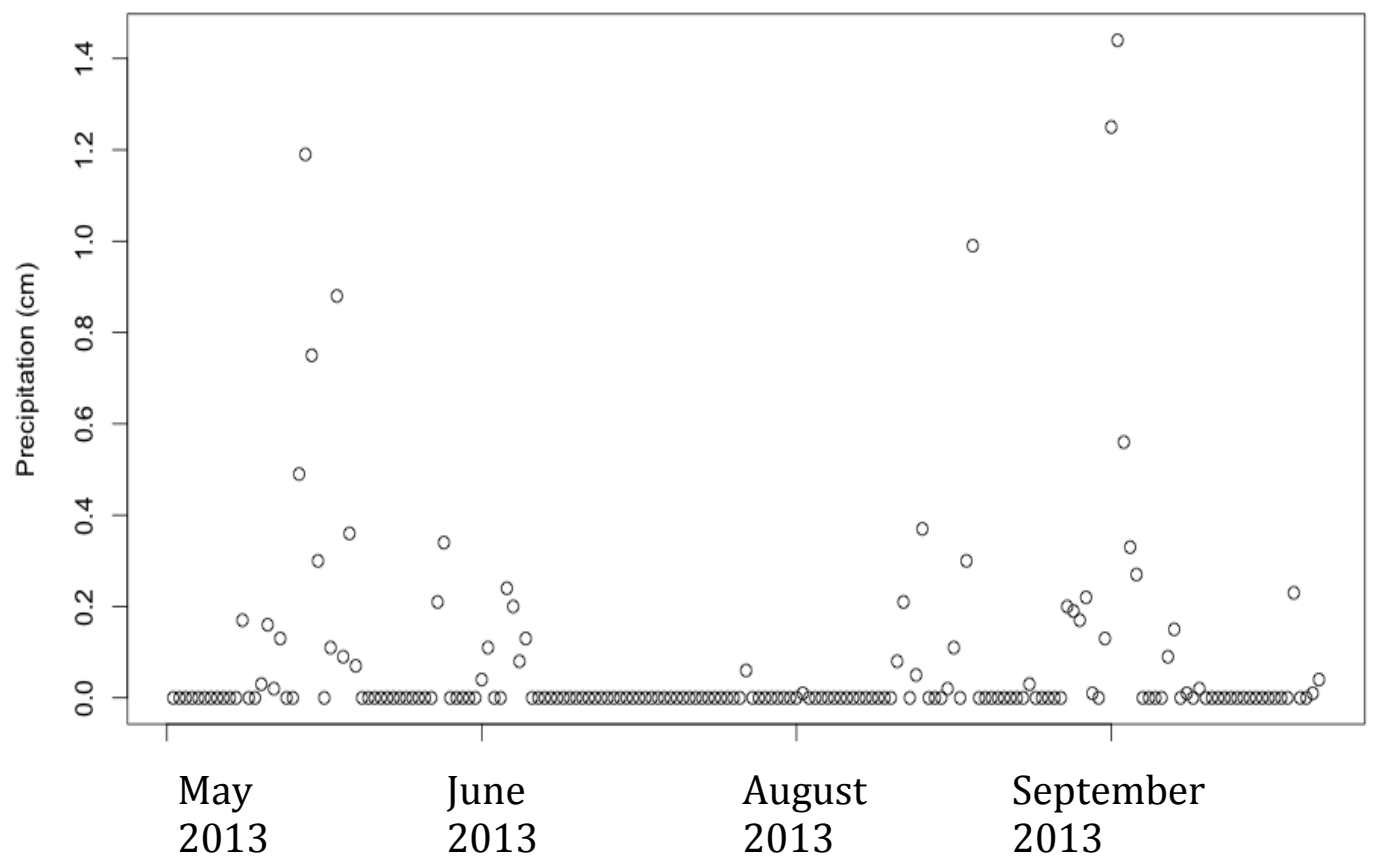

Figure 18: Total precipitation in Portland, Oregon between May 1, 2013 and October 1, 2013. Precipitation data comes from the NOAA meteorological station at the Portland International Airport. 
Table 8: Mean total precipitation and mean departure from normal precipitation in Portland, Oregon between May 1, 2013 and October 1, 2013. Data show unseasonably high rains in September 2013.

\begin{tabular}{|c|c|c|}
\hline Month & Precip total & $\begin{array}{c}\text { Precip } \\
\text { departure }\end{array}$ \\
\hline May-13 & 4.75 & 2.28 \\
\hline Jun-13 & 1.35 & -0.35 \\
\hline Jul-13 & Trace & -0.65 \\
\hline Aug-13 & 0.78 & 0.11 \\
\hline Sep-13 & 5.62 & 4.15 \\
\hline Oct-13 & $1.15 !$ & -1.85 \\
\hline
\end{tabular}

Table 9: Mean $\pm \mathrm{SE}$ vapor pressure deficit (VPD) for predawn and midday sampling times across early, mid, and late summer water relation data collection.

\begin{tabular}{|c|c|c|}
\hline Season & $\begin{array}{c}\text { Time of } \\
\text { Day }\end{array}$ & $\begin{array}{c}\text { VPD } \\
\text { mean士 } \\
\text { SE }\end{array}$ \\
\hline \multirow[t]{2}{*}{$\begin{array}{c}\text { Early } \\
\text { Summer }\end{array}$} & Predawn & $\begin{array}{c}6.678 \pm \\
0.592\end{array}$ \\
\hline & midday & $\begin{array}{l}7.8 \pm \\
0.216\end{array}$ \\
\hline \multirow{2}{*}{$\begin{array}{c}\text { Mid- } \\
\text { summer }\end{array}$} & Predawn & $\begin{array}{r}2.517 \\
\pm 0.010\end{array}$ \\
\hline & midday & $\begin{array}{l}8.47 \pm \\
0.190\end{array}$ \\
\hline \multirow{2}{*}{$\begin{array}{c}\text { Late } \\
\text { Summer }\end{array}$} & Predawn & $\begin{array}{l}2.268 \pm \\
0.0364\end{array}$ \\
\hline & midday & $\begin{array}{l}4.78 \pm \\
0.227\end{array}$ \\
\hline
\end{tabular}


Table 10: Kruskal Wallis nonparametric ANOVA with a Kruskal multiple comparison test for predawn and midday sampling periods across seasons showing differences in vapor pressure deficit (VPD) across the three sampling periods. Different lowercase letters represent significant difference $(\mathrm{P}<0.05)$.

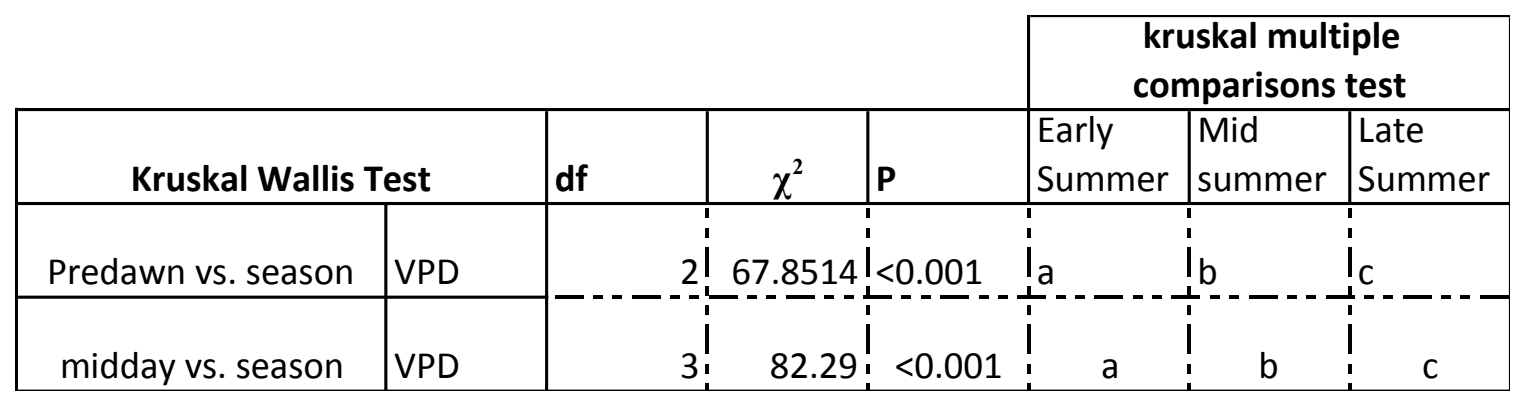


Table 11: Mean and standard error of VWC of soil and species specific water status measurements across the three sampling periods- early summer, mid-summer, and late summer. Additionally, an analysis of variance and Tukey HSD post hoc test was performed and different small letters represent variables that are statistically significant $(\mathrm{P}<0.05)$. Codes were used for clarity: H. tenuipes (HYTE), V. hexandra (VAHE), English ivy (Ivy), Stomatal conductance $\left(\mathrm{g}_{\mathrm{s}}\right)$ measured in $\mathrm{mmol} \mathrm{m} \mathrm{m}^{-2} \mathrm{~s}^{-1}$, predawn and midday water potential ( $\Psi \mathrm{pd}, \Psi \mathrm{md})$ measured in megapascals $(\mathrm{MPa})$, and volumetric water content $(\% \mathrm{VWC})$.

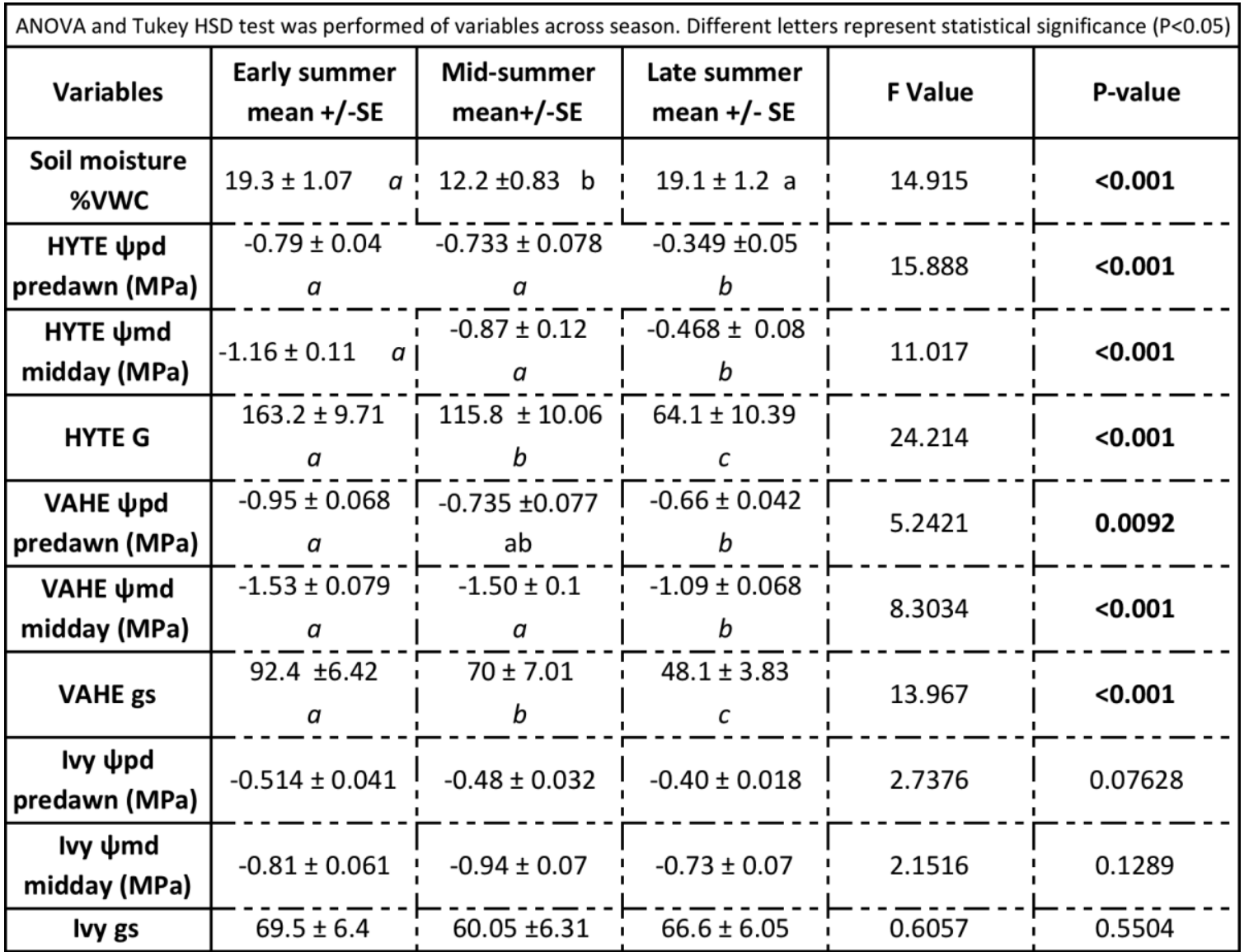




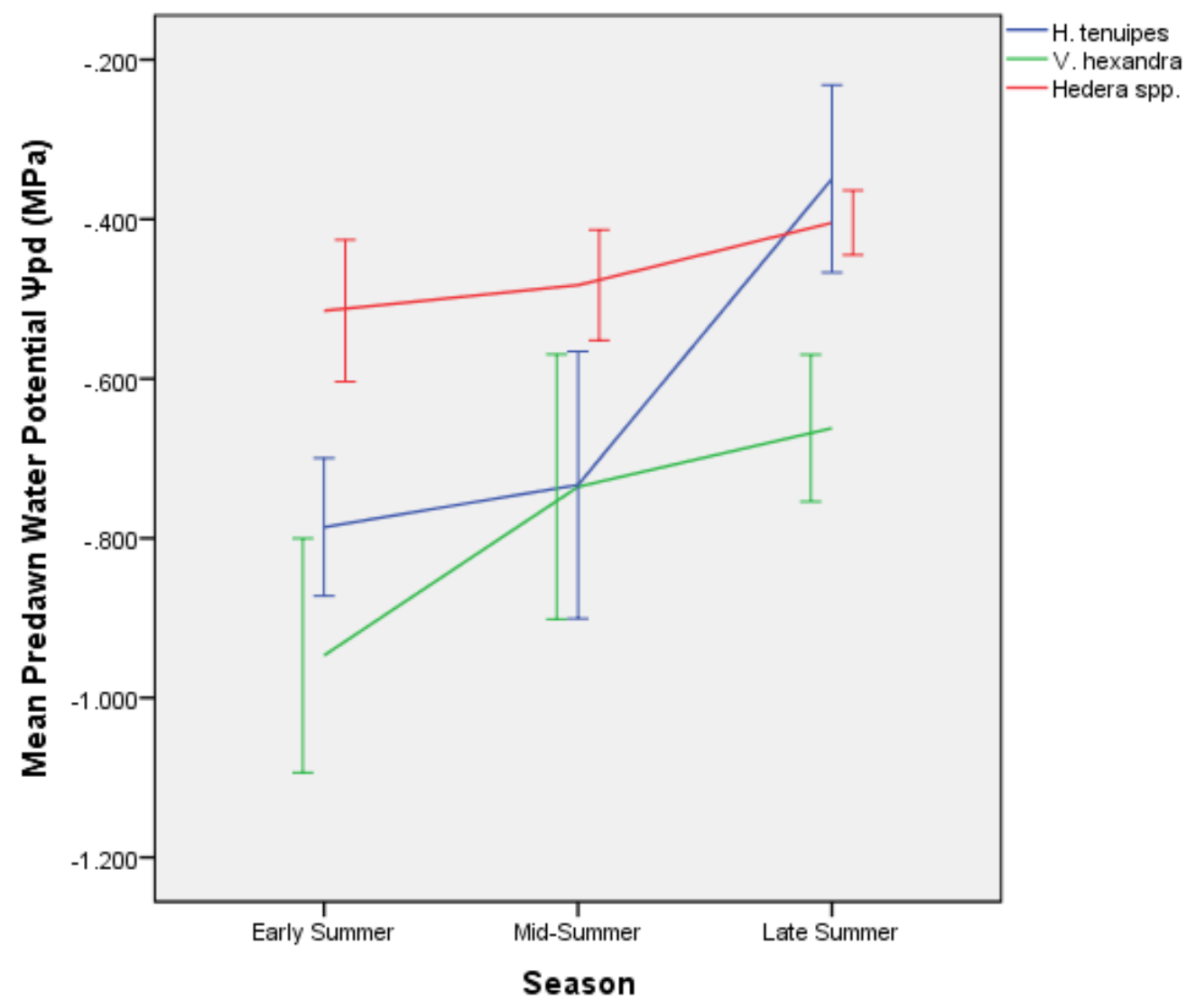

Error bars: $95 \% \mathrm{Cl}$

Figure 19: Mean predawn water $\left(\Psi_{\mathrm{pd}}\right)$ potential for the three co-occurring study species across the three sample periods: early summer, mid-summer, and late summer. As the summer progressed, predawn water potential for the two native herbs becomes less negative while English ivy potential does not change. Error bars represent $95 \%$ confidence interval. 


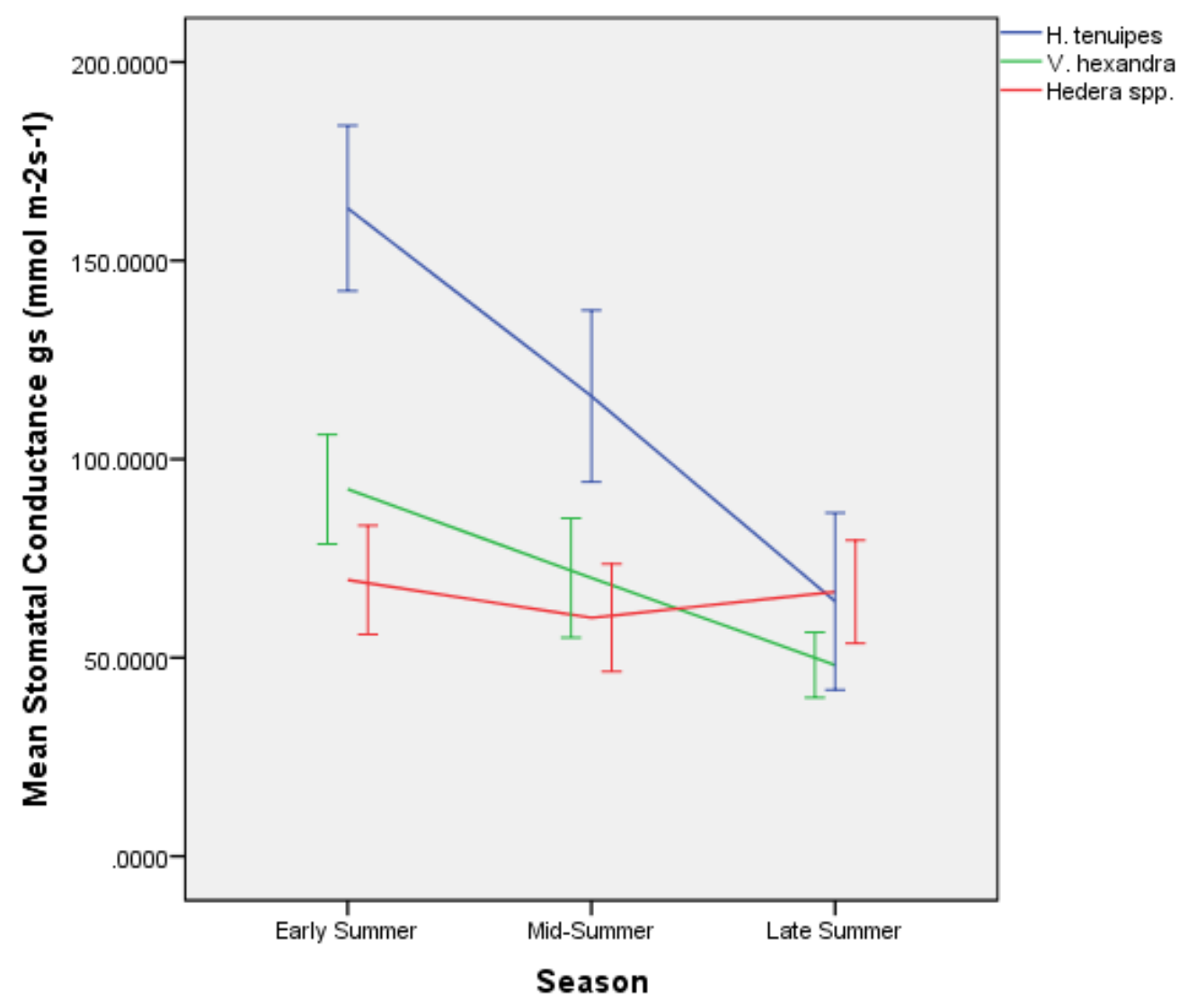

Error bars: $95 \% \mathrm{Cl}$

Figure 20: Mean stomatal conductance (gs) for the three co-occurring study species across the three sample periods: early summer, mid-summer, and late summer. As the summer progressed, the stomatal conductance for the two native herbs decreases while English ivy conductance does not change. Error bars represent 95\% confidence interval. 


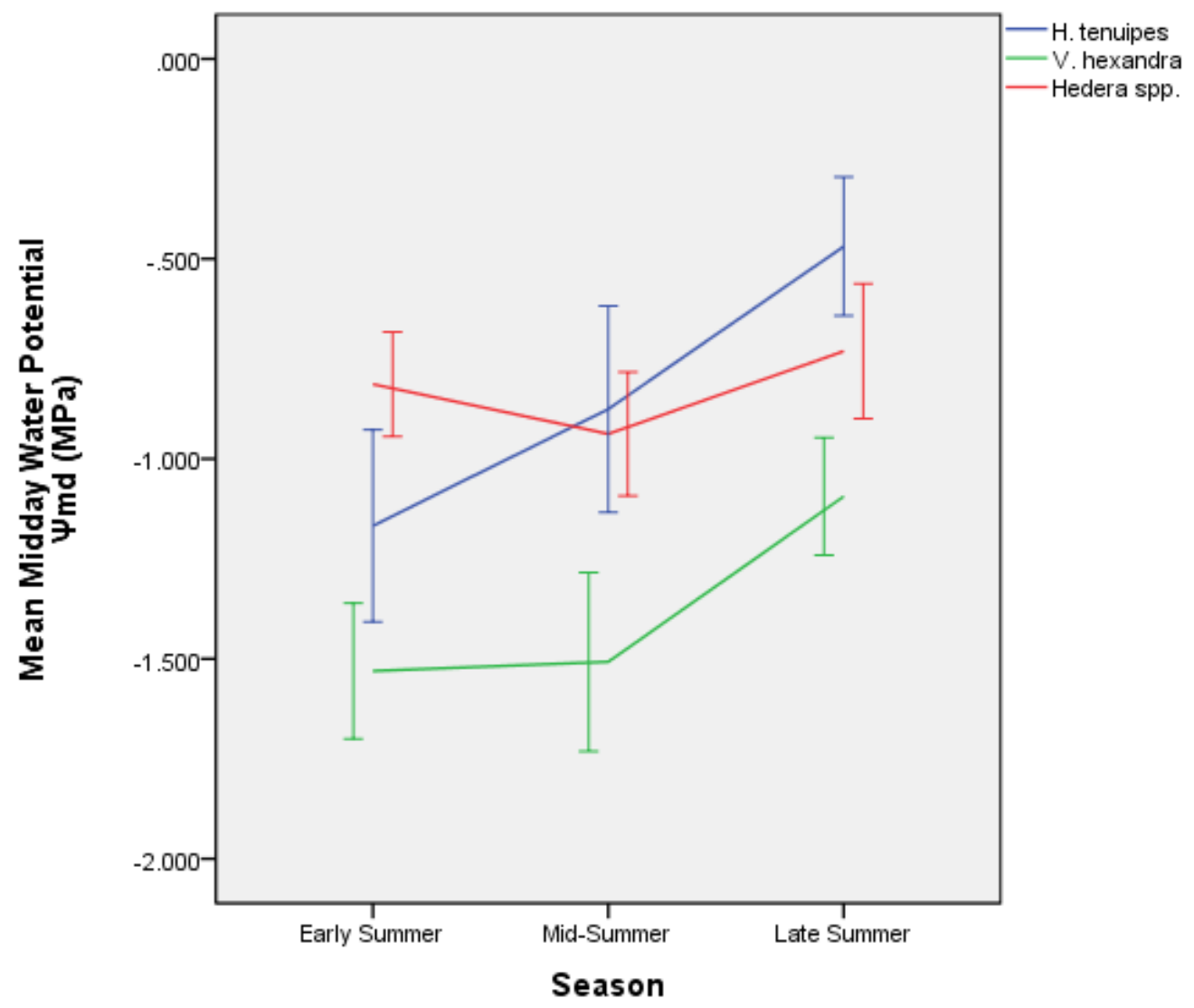

Error bars: $95 \% \mathrm{Cl}$

Figure 21: Mean midday water potential $\left(\Psi_{\mathrm{md}}\right)$ for the three co-occurring study species across the three sample periods: early summer, mid-summer, and late summer. As the summer progressed, mid-day water potential for the two native herbs becomes less negative while English ivy potential does not change. Error bars represent 95\% confidence interval. 


\section{Discussion:}

Change over time:

Percent cover of English ivy increased more than the cover of native understory species between the years of 2010 and 2013. Overall, ivy cover increased on average $14 \%$ whereas the total native understory increased $<1 \%$. In this study, ivy was found to proliferate three times faster than the average understory species in Forest Park. The rapid difference in cover between native species and ivy could be associated with differences in life history, resource access, or competitive ability (Grime, 1977; Silvertown et al., 1993). Ivy is water efficient and may have access to distant water resources allowing little change in water relations during the summer. While the native herbaceous or deciduous perennials are dormant in the winter (Bierzyhudek, 1982), English ivy is capable of using increased levels of winter light under deciduous forest canopies to fuel high spring vegetative growth rates (Holloway \& Rosenstiel, 2013). The faster ivy can spread, the faster it can alter the understory forest community. Given an average $4.6 \%$ cover increase a year, it could take less than 10 years for ivy to reach the $44 \%$ threshold where it may begin to impact the understory community composition.

\section{Changes in Community Composition:}

a) Richness and Diversity:

Changes in diversity indices across both the ivy cover categories and across the distribution of ivy were predominantly consistent with our hypothesis, and indicate that high densities of ivy lead to a significant reduction in understory diversity and richness. Understory evenness did not change across the various ivy densities, yet both 
richness and Shannon Wiener's diversity significantly decreased, suggesting impacts to the understory community. The change in diversity and richness were not associated with environmental variation, thus the abiotic factors may not control the negative relationship in these plots. The negative effects on species richness were not evenly distributed across understory functional groups, native shrub richness did not change while native herb and fern richness were significantly reduced in high ivy plots. The reduction seen in richness can primarily be attributed to a reduction of native herbaceous species in high ivy plots, suggesting that herbs were the most impacted out of the three dominant functional groups. Both mean diversity and richness became significantly reduced in plots with greater than $43.75 \%$ ivy cover, implying that there may be a minimum level of invasion at approximately $44 \%$ ivy.

\section{b) Cover and relative abundance:}

Cover and relative abundance changed across both the ivy cover categories and across the distribution of ivy, implying results were partially consistent with most aspects of our hypothesis. The various functional groups in addition to individual plant taxa responded differently to increasing ivy invasion, but responses of individual species were masked at the functional group level. As a whole, the native herbaceous understory significantly decreased across the gradient of ivy, but at the species level, A. triphylla, Carex spp., D. hookeri, G. triflorum, and V. glabella were the most negatively impacted by ivy invasion, seeing reduction in both cover and relative abundance in sites with more than $43.75 \%$ ivy cover. Hydrophyllum tenuipes cover remained constant throughout the sites, yet the relative abundance of $H$. tenuipes was lower in high ivy plots. The discrepancy between 
cover and relative abundance was attributed to the higher total understory cover seen in high ivy sites. As a functional group, native understory shrub cover declined during the early stages of invasion when ivy cover was between $12.75 \%$ and $43.75 \%$, but subsequently increased in later stages of invasion. At a species level, only one shrub species, $M$. nervosa, was reduced by the invasion of ivy, the cover and relative abundance of the remainder of the shrub species did not change. The mean cover of native ferns and allies did not significantly decrease across ivy groupings, yet at a species level, the dominant fern P. munitum decreased while the less dominant $A$. filix-femina increased across increasing degrees of ivy cover. Reductions in both cover and relative abundance of all impacted taxa were predominately associated with plots over $43.75 \%$ ivy cover, again implying a minimum level of ivy invasion in which the native species become impacted. Although the Kruskal Wallis ANOVA showed significant cover changes in a few individual herb, fern, and shrub species, the Kruskal multiple comparison test only found significant changes for the two native species, both with the highest cover values. The lack of significance is due to the low total cover of many of the individual native understory species and the lack of sensitivity in nonparametric multiple comparison tests.

\section{c) Species dominance in multiple dimensions:}

Community composition of the understory changed across low, medium, and high ivy cover. In high ivy cover ( $>43.75 \%)$ the community was significantly different than the community in low ivy cover $(0-12.75 \%)$, as is represented by changes in the distribution of species. The change in distribution of individual species seen in the ordination was similar to the changes seen in cover and relative abundance discussed 
above. Sites with high ivy cover over $43.75 \%$ were characterized with high $A$. filixfemina, low M. nervosa, fewer herbaceous species, and generally less P. munitum, while the opposite is true for sites with low ivy cover. The association of environmental variation with changes in community composition likely accompanies ivy to explain the change seen in the understory community. High ivy cover sites were associated with high deciduous canopy cover and high soil moisture while sites with low ivy cover were associated with high litter depth and high conifer canopy cover. Polysticum munitum and M. nervosa could be responding to ivy competition for light and high soil moisture.

Functional groups and each individual taxa responded differently to the invasion of ivy as seen by changes in species richness, species cover, relative abundance, and distribution across the ordination. The response may be a direct result of competition with ivy, a change in the environmental gradient seen in ivy invasion including high soil moisture and high deciduous canopy cover, or the interaction between the two. As a group, herbaceous species were the most impacted by high ivy cover. Herbaceous species may be in direct competition for valuable forest resources, and those species with the ability to compete will survive. Some herbs have extensive root systems that allow for belowground resource extraction throughout the growing season (Antos \& Zobel, 1984). The composition of herbs may also be a result of an environmental gradient. Herbs associated with higher soil moisture and high deciduous canopy cover may be more likely to survive in high densities of ivy cover. Likely, the herb response is a result of the interaction between competition and environmental variation. Native H. tenuipes thrives in moist soil conditions and is thought to compete well with English ivy for 
resources (Waggy, 2010), thus mean cover did not change across the sites. On the other hand, V. glabella also thrives in moist soil conditions (Brun, 2014), but may poorly compete with ivy for forest resources.

Shrubs and ferns had a variable response to ivy invasion because of three possible factors. First, shrubs and ferns can be long lived (Emmingham, 1998; Soltis \& Soltis, 1987), so probably were established before the invasion of ivy. Second, many of the shrubs and ferns may not be directly competing with ivy for resources. Some of the native shrubs and ferns are deeply rooted or have extensive root systems that may allow them to extract resources from different soil locations (Antos \& Halpern, 1997; Huffman \& Tappeiner, 1997; Lezberg et al., 1999). Also both shrubs and ferns are able to grow above the dense mat of ivy allowing for adequate light, yet do not climb high enough into the canopy to be used as a support system for ivy. Third, the distribution may be the result of an environmental gradient. As seen in the ordination, the shrub and fern variability could be explained by the change in soil moisture and composition of canopy cover across the forest. Polysticum munitum and M. nervosa both prefer drier soil conditions under a conifer canopy cover, while A. filix-femina and Tolmiea menziesii can thrive on moister soil conditions under a deciduous canopy (Hibbs \& Bower, 2001; Lookingbill et al., 2004; Pabst \& Spies, 1997; Tirmenstein, 1989).

Taken together, this study provides evidence that increasing degrees of ivy invasion not only reduce plant diversity and richness, but can also lead to changes in species composition. Both functional groups as well as individual plant taxa respond differently to increasing ivy invasion. Environmental variation did not appear to be 
associated with changes in richness and diversity but was associated with changes in community composition. Prior studies confirm these results. Nonnative cape ivy (Delairea odorata) was associated with richness, diversity and herb reduction in invaded plots while there was no clear reduction in shrubs and ferns (Alvarez \& Cushman, 2002). In a Washington study, Hedera hibernica cover was also correlated to a clear reduction in native species diversity (Ramsey, 2005). Other studies challenged our results. Quinn \& Best (2002), found a decrease in diversity with increasing Hedera helix cover in Stanley Park, Washington, with most of the reductions occurring in the shrub and moss layers. Finally, Dlugosch (2005) who studied English ivy in Seattle's urban parks found no clear reduction in the diversity indices and the only changes in understory cover were attributed to a decline in native shrubs. Dlugosch (2005) may have found different results because she analyzed sites in the early stages of invasion rather than across the gradient of ivy invasion as done in this study. The lack of shrub response seen in our study could also be attributed to two reasons. First, shrub diversity and total shrub cover in Balch and Coyote Research Plot may be low compared to Forest Park as a whole thereby reducing the chance of ivy impact on understory shrubs. Both Quinn \& Best (2002) and Dlugosch (2005) found that the native shrub Gaultheria shallon was significantly impacted by English ivy. Since G. shallon was not located in any of our plots, these results were not co corroborated.

\section{Change in soil moisture:}

Volumetric water content of the soil increased with high densities of ivy cover. Increases in soil moisture and ivy were also associated with an increase in 
deciduous cover, decrease in conifer cover, decrease in litter depth, and decrease in slope. These results suggest that ivy does not deplete soil moisture in homogenous stands.

Multiple factors could be at play in the relationship with ivy and soil moisture. First, English ivy may extract soil water from a different source than the native cooccurring understory species (See next section); thereby not reducing soil moisture directly below rooted stem. Second, English ivy may have the ability to alter the moisture of the soil. Ivy can form dense mats on the forest floor reducing light availability below the ivy (Personal Observation). The combinations of reduced light and increase in total vegetation cover over the soil (Dlugosch, 2005), may decrease evaporation off the soil surface, and could actually increase soil moisture below dense ivy patches. Additionally, because ivy is a woody, evergreen vine, water loss through transpiration is low (Leuzinger et al., 2011; Zhu \& Cao, 2009). These findings were confirmed by the data from our water status results. Third, ivy may just be in higher densities on soils with higher soil moisture. Ivy is able to thrive in sites with moist soils, and is thought by some to be a moist site indicator (Metcalf, 2005). Finally, the displacement of less water efficient native understory species by the water efficient vine, ivy, may change the hydrology by transpiring less water through the summer months. A similar pattern is seen by nonnative Bromus tectorum in south-central Washington. Cline et al. (1997) found that communities with B. tectorum lost less soil moisture than adjacent native shrub dominated communities. 
Results also show that the increase in soil moisture is also associated with a change in slope and change in the overstory composition from primarily conifer to primarily deciduous cover. Soil moisture distribution is known to be strongly associated with topography, hill slope, and soil properties (Yeakley et al., 1998). In this study, the location of plot on the hill slope and the soil properties were not directly measured. Soil properties may have played a part in the distribution of soil moisture, however in Forest Park the soil is primarily silty loam (NRCS, 2014). The location on hill slope can be associated with slope, as topography changes the slopes and soil moisture runoff increase (Western et al., 2002). Finally, the relationship with soil moisture and overstory canopy composition could be related to at least two other factors. Deciduous species may prefer moister soils compared to conifer species. Acer macrophyllum, primary tree in the overstory deciduous canopy of this study, is not efficient at using water, and develops best on moist sites (Davis, 2005; Franklin \& Dryness, 1973). Conifers, on the other hand, have tight control over water use that allows them to survive in dry soils (Waring \& Franklin, 1979).

\section{Water Relations:}

a) Water Status of Ivy:

Water potential and stomatal conductance of ivy did not change throughout the summer months. These results indicate that ivy may not take advantage of seasonally limiting soil moisture seen in the Pacific Northwest to invade the forest understory. The predawn water potential, midday water potential, and stomatal conductance remained 
constant throughout the summer, given summer changes in soil moisture (\%VWC), vapor pressure deficit, and predawn water potential for co-occurring herbs.

Results suggest that ivy may be able to acquire and or efficiently use water, thus allowing for little change in water potential throughout the summer. Interspecific differences in predawn water potential throughout the season suggest that English ivy, similar to tropical lianas (Cai et al., 2009), may draw from a different water source compared to the native co-occurring herbs. The deep, complex root systems of tropical lianas allow for access to deeper sources of water compared to co-occurring tropical species (Schnitzer \& Bongers, 2011; Zhu \& Cao, 2009). Unlike tropical lianas, English ivy has a shallow root system, rooting around $9.6 \mathrm{~cm}$ deep, that can stretch over $30 \mathrm{~m}$ across the forest floor that may allow for movement of water across the forest floor (Okerman, 2000; Sack et al., 2003).

The physiological attributes of ivy that allow for efficient water use may also explain the lack of water status change throughout the summer. Ivy has high water holding capacity, thick waxy cuticle, tight control over stomata, and water transport efficiency that has allowed for a conservative water use strategy (Feldman et al., 1997; Leuzinger et al., 2011; Metcalf, 2005; Zhu \& Cao, 2009). The consistently low stomatal conductance throughout the summer also suggests that ivy does not increase its carbon accumulation rate in the summer, even if ivy shows no signs of water stress. Previous studies have found that carbon acquisition and photosynthetic capacity was highest during early spring and winter months (Leuzinger et al., 2011; Holloway \& Rosenstiel, 2013) while the deciduous canopy was dormant. Because ivy accumulates 
photosynthates in the spring and winter months it does not need to have high conductance in the summer months. The low conductance also suggests that during the summer months ivy does not transpire water at great rates, consequently it may not compete with co-occurring species for available soil moisture.

b) Water Status of Herbs:

Water potential and stomatal conductance of the herbaceous species significantly changes throughout the summer growing season. Midday water potential was the least negative in late summer while stomatal conductance was the highest in early summer. Results suggest that in the summer months of 2013, herbs did not experience enough water stress to reduce photosynthetic activity. This study found that in early summer when the water was the least available, both native herbs did not reduce stomatal conductance. On the other hand, in the late summer when water was most available, conductance was the lowest suggesting lower carbon accumulation. This pattern could be explained by the life history traits of herbs. First, the low conductance in late summer could be due to the seasonal life history traits of understory herbs. In late summer understory herbs may become physiologically inactive once flowering is complete and leaves are beginning to senesce (Knapp \& Smith, 1989). Second, although the herbs showed some water stress in early summer, it may have not been enough to reduce conductance. The extensive network of belowground structures may have allowed the herbs to experience a higher level of water stress (Antos \& Halpern, 1997) before the stomatal conductance became impacted. 


\section{Conclusions and Management implications:}

Invasive species can impact a community by altering native plant distributions and decrease diversity by suppressing native plants (Hejda et al., 2009; Urgenson et al., 2009). Communities that have fluctuations in resource supply are said to be more susceptible to invasion. Forest Park is becoming dominated by invasive ivy (Hedera spp.). This research has suggested that invasive ivy is increasing more than twice as fast as most native understory species. Given time ivy may have the ability to invade most locations in Forest Park. Once established, invasive ivy (Hedera spp.) has the ability to alter the understory community composition by reducing diversity and richness and suppressing native understory species.

Our results show that ivy does not use seasonally limiting soil moisture to invade forest understory. In a forest with seasonally limiting soil moisture, English ivy, unlike many local species, has tight control of water use and also may have the ability to access different water sources. With the invasion of ivy there are patterns of increased soil moisture and deciduous overstory cover that may perpetuate the dominance of ivy; similarly altering the composition of understory species ultimately favoring competitive hydrophilic species.

In a forest community, much of the biodiversity resides in the native herbaceous plant community (Gilliam, 2007). In order to maintain and enhance biodiversity in Forest Park (City of Portland, 1995), forest managers should continue removing English ivy. Managers should focus on removal and restoration of the native herbaceous plants that are the most impacted and that offer refugia, nutrient cycling and resources for 
countless organisms (plant and animal alike) in a way that a monoculture of ivy may not (Gilliam 2007). Our study suggests that native understory species negatively respond after ivy cover exceeds $44 \%$. When identifying areas for ivy removal and understory restoration managers should choose locations with $<44 \%$ ivy cover. Removing ivy before it negatively impacts the understory community may increase the likelihood of restoration success. Additionally, when choosing species to plant in ivy invaded communities managers should first, choose species that can survive in the high deciduous canopy and high soil moisture conditions and second, choose species that may be less impacted by ivy invasion. Finally, managing for secondary successional conifer canopy trees that provide year-round shade may reduce the spread of ivy into the forest community. 


\section{Study Limitations and Future Research:}

One major limitation of this study is that this research was observational rather than experimental, thus results focus on correlations rather than cause and effect. Similarly, the environmental variables including volumetric water content of the soil was measured once throughout the season across the gradient of ivy invasion, therefore we are not able to accurately understand how ivy is interacting across the environmental gradient. Additional experiments relating to interspecific competition between natives understory species and invasive ivy across light and soil moisture gradients may allow researchers to directly understand how ivy and native species compete for resources. Additionally, it may allow us to understand if any native understory species can outcompete ivy and possibly reduce the overall abundance of ivy. Another limitation of this research is the physiological study. This study had a small sample size, inaccurate light measurements, and only occurred through the summer months, thus limiting the full understanding how each species uses water throughout the

year. A physiological study that occurs year-round with a larger sample size, and measurements of photosynthetic photon flux density may shed light on exactly how native herbs and English ivy use water throughout the year. By examining year round water fluxes we could understand how ivy uses water in the winter and early spring months when the native species are dormant.

A more extensive study examining invasion and associated impacts over time (ten years or more) would also give researchers a better understanding of how ivy changes the composition throughout time. 


\section{Concluding remarks:}

Collectively, these results suggest that Hedera spp. spreads faster than any of the documented native understory species. Once ivy has reached $44 \%$ cover the forest understory significantly shifts species composition and soil moisture increases. This study suggests that ivy does not take advantage of limited soil moisture during the summer to invade the forest community, yet it is more efficient at using water compared to two native understory herbs, suggesting superior competitive advantage. Lianas like Hedera spp. have unique life history strategies that allow them to persist and dominant in urban temperate forest communities such as Forest Park. 


\section{References:}

Alvarez, M., Cushman, J. (2002). Community-level consequences of a plant invasion: effects on three habitats in coastal California. Ecological Applications, 12(5), 1434-1444.

Andrade, J., Meinzer, F., Goldstein, G., Schnitzer, S. (2005). Water uptake and transport in lianas and co-occurring trees of a seasonally dry tropical forest. Trees, 19, 282289.

Antos, J., Halpern, C. (1997). Root system differences among species: implications for early successional changes in forest of Western Oregon. American Midland Naturalist, 138(1), 97-108.

Antos, J., Zobel, D. (1984). Ecological implications of belowground morphology of nine coniferous forest herbs. Botanical Gazette, 508-517.

Bailey, J., Mayrsohn, C., Doescher, P., St. Pierre, E., Tappeiner, J. (1998). Understory vegetation in old and young Douglas-fir forests of western Oregon. Forest Ecology and Management, 112, 289-302.

Bais, H., Vepachedu, R., Gilroy, S., Callaway, R., Vivanco, J. (2003). Allelopathy and exotic plant invasion from molecules and genes to species interactions. Science, 301, 1377-1380.

Barbour, M., Burk, J., Pitts, W. (1987). Terrestrial Plant Ecology, Second Edition. Menlo Park, California: The Benjamin/Cummings Publishing Company, Inc.

Barker, M., Perez-Salicrup, D. (2000). Comparative water relations of mature mahogany (Swietenia macrophylla) trees with and without lianas in a subhumid, seasonally dry forest in Bolivia. Tree Physiology, 20, 1167-1174.

Bazzaz, F. A. (1979). The physiological ecology of plant succession. Annual Reviews of Ecological Systems, 10(1), 351-371.

Bhattarai, K., Vetaas, O. (2003). Variation in plant species richness of different life forms along a subtropical elevation gradient in the Himalayas, East Nepal. Global Ecology and Biogeography, 12(4), 327-340.

Bierzychudek, P. (1982). Life histories and demography of shade-tolerant temperate forest herbs: a review. New Phytologist, 90(4), 757-776. 
Biggerstaff, M., Beck, C. (2007). Effects of method of English ivy removal and seed addition on regeneration of vegetation in a southeastern piedmont forest. American Midland Naturalist, 158(1), 206-220.

Bonanomi, G., Sicurezza, M., Caporaso, S., Esposito, A., Mazzoleni, S. (2006). Phytotoxicity dynamics of decaying plant materials. New Phytologist, 169(3), 571-578.

Broshot, N. E. (2011). Mortality and recruitment in an urban forest (Forest Park in Portland, Oregon) between 1993 and 2003. Urban Ecosystems, 14(4), 553-567.

Broshot, N. E. (2007). The influence of urbanization on forest stand dynamics in Northwestern Oregon. Urban Ecosystems, 10, 285-298.

Brun, C. (2014). Stream violets (Viola glabella). Washington State University, Clark County Extension, PNW Plants. Accessed April 14, 2014.

Cai, Z., Schnitzer, S., Bongers, F. (2009). Seasonal differences in leaf-level physiology give lianas a competitive advantage over trees in tropical seasonal forest. Oecologia, 161, 25-33.

Caplan, J. (2009). The role of water and other resources in the invasion of Rubus armeniacus in Pacific Northwest ecosystems. Environmental Science and Resources, Portland State University, Portland, Oregon: Dissertation.

Caplan, J., Yeakley, A. (2010). Water relations advantages for invasive Rubus armeniacus over two native ruderal congeners. Plant Ecology, 210,169-179.

Carter, G., Teramura, A. (1988). Vine photosynthesis and relationships to climbing mechanics in a forest understory. American Journal of Botany, 75(7), 1011-1018.

Chaves, M. M., Pereira, J. S., Maroco, J., Rodrigues, M. L., Ricardo, C. P. P., Osorio, M. L., Carvalho, I., Faria, T., Pinheiro, C. (2002). How plants cope with water stress in the field? Photosynthesis and growth. Annals of Botany, 89(7), 907-916.

City of Portland. (1995). Forest Park natural resources management plan. Portland Parks $\&$ Recreation and Bureau of Planning. Ordinance no. 168509. Portland, Oregon.

Clarke, K (1993). Non-parametric multivariate analyses of changes in community structure. Australian Journal of Ecology, 18, 117-143. 
Clarke, M., Reichard, S., Hamilton, C. (2006). Prevalence of different horticultural taxa of ivy (Hedera spp., Araliaceae) in invading populations. Biological Invasions, 8(2), 149-157.

Clergeau, P. (1992). The effect of birds on seed germination of fleshy-fruited plants in temperate farmland. Acta Oecologica, 13, 679-686.

Copp, S. (2012) Impacts of ivy removal on the forest understory community. Unpublished raw data.

D'Antonio, C., Meyerson, L. A. (2002). Exotic plant species as problems and solutions in ecological restoration: a synthesis. Restoration Ecology, 10(4), 703-713.

D'Antonio, C. M., Vitousek, P. M. (1992). Biological invasions by exotic grasses, the grass/fire cycle, and global change. Annual review of ecology and systematics, $23,63-87$.

Daehler, C. (2003). Performance comparisons of co-occurring native and alien invasive plants: implications for conservation and restoration. Annual Review of Ecology, Evolution, and Systematics, 34, 183-211.

Davis, M., Grime, P., Thompson, K. (2000). Fluctuating resources in plant communities: a general theory of invasibility. Journal of Ecology, 88, 528-534.

Davis, K. (2005). Comparison of the water relations characteristics of woody plants in Western Oregon. Botany and Plant Pathology, Oregon State University, Oregon: Master's Thesis.

Dlugosch, K. (2005). Understory community changes associated with English ivy invasions in Seattle's urban parks. Northwest Science. 79(1), 52-59.

Dolan, B. (2012). Effects of increased nitrogen deposition on the dominance of Hedera helix in the Pacific Northwest. Environmental Science and Management, Portland State University, Oregon: Master's Thesis.

Deshler, John (2012). Forest Park Wildlife Report. Portland Parks and Recreation, p. 16.

Dyrness, C., Acker, S. (2010). Ecology of common understory plants in Northwestern Oregon and Southwestern Washington Forests. Retrieved from: andrewsforest.oregonstate.edu.

Dyrness, C., Franklin, J., Moir, W. (1974). A preliminary classification of forest communities in the central portion of the Western Cascades in Oregon. US/IBP, 
Coniferous Forest Biome Bulletin 4. Coniferous Forest Biome, College of Forest Resources, University of Washington, Seattle, Washington, USA.

Elzinga, C., Salzer, D., Willoughby, J. (1998). Measuring and monitoring plant populations. Bureau of Land Management technical reference: 1730-1.

Emmingham, B. (1998). Uneven-ages management in the Pacific Northwest. Journal of Forestry, 96(7), 37-39.

Fahey, R., Puettmann, K. (2008). Patterns in spatial extent of gap influence on understory plant communities. Forest Ecology and Management, 255, 2801-2810.

Farquhar, G., Sharkey, T. (1982). Stomatal Conductance and Photosynthesis. Annual review of plant physiology, 33(1), 317-345.

Feldman, W. R., Carter, S. A., Stone, K. W. (1997). Water requirements of arid-adapted groundcover and subshrub species for landscape use in Arizona. Desert Plants, 13(1), 18-24.

Feir-Walsh, B., Toothaker, L. (1974). An empirical comparison of the ANOVA F-test, normal scores test and Kruskal-Wallis test under violation of assumptions. Education and Psychological Measurement, 34, 789-799.

Finzi, A., Canham, C., Breemen, N. (1998). Canopy Tree-soil interactions within temperate forests: species effects on $\mathrm{pH}$ and cations. Ecological Applications, $8(2), 447-454$.

Franklin J., Dyrness C. (1988). Natural vegetation of Oregon and Washington. Oregon State University Press, Corvallis.

Franklin, J., Spies, T. (1991). Composition, function, and structure of old-growth Douglas-fir forests. Wildlife and Vegetation of Unmanaged Douglas-fir Forests. USDA Forest Service General Technical Report PNW-GTR-285, 71-80.

Franklin, J. Thomas, S., Van Pelt, R., Carey, A., Thornburgh, D., Rae Berg, D., Lindemayer, D., Harmon, M., Keeton, W., Shaw, D., Bible, K., Chen, J. (2002). Disturbances and structural development of natural forest ecosystems with silvicultural implications, using Douglas-fir forests as an example. Forest Ecology and Management, 155, 399-423.

Gerwing, J., Vidal, E. (2002). Changes in liana abundance and species diversity eight years after liana cutting and logging in an Eastern Amazonian forest.

Conservation Biology, 16(2), 544-548. 
Giblin, D. (n.d.) Hydrophyllum tenuipes, Pacific waterleaf. Burke Museum of Natural History and Culture. April 20, 2014. Retrieved from: http://biology.burke.washington.edu/herbarium/imagecollection.php.

Gilbert, B., Lechowicz, M. (2005). Invasibility and abiotic gradients: The positive correlation between native and exotic plant diversity. Ecology, 86(7), 1848-1855.

Gilliam, F. (2007). The ecological significance of the herbaceous layer in temperate forest ecosystems. BioScience, 57(10), 845-858.

Gray, A., Spies, T., Easter, M. (2002). Microclimate and soil moisture responses to gap formation in coastal Douglas-fir forests. Canadian Journal of Forest Research, 32(2), 332-343.

Grime, J. P., Hodgson, J. G., \& Hunt, R. (1988). Comparative plant ecology. A functional approach to common British species. London, UK: Unwin Hyman.

Grime, J. (1977). Evidence for the existence of three primary strategies in plants and its relevance to ecological and evolutionary theory. The American Naturalist, 111(982), 1169-1194.

Gurevitch, J., Scheiner, S., Fox, G. (2005). Water relations and energy balance. The Ecology of Plants, Second Edition. Sunderland, MA: Sinauer Associates, Inc.

Haitan, Z., Jianping, T., Lian, W., Juan, Z., Yuping, W., Ze, H., Jinzian, L., Qingzue, G. (2011). Influences of herbaceous vines on community characteristics in pioneer succession stages. Acta Ecologica Sinica, 31,186-191.

Hejda, M., Pysek, P., Jarosik, V. (2009). Impact of invasive plants on species richness, diversity and composition of invaded communities. Journal of Ecology, 97, 393403.

Hibbs, D., Bower, A. (2001). Riparian forests in the Oregon Coastal Range. Forest Ecology and Management, 154, 201-213.

Holloway, L., Rosenstiel, T. (2013). Physiological response of invasive ivy (Hedera spp.) to the seasonal light cycle: taking photosynthetic advantage of winter canopy loss. Poster presented at the Northwest Science Association Annual Meeting, Portland, Oregon. Abstract received from: http://www.northwestscience.org.

Hsiao, T. C., Edmundo A. (1974). Plant responses to water deficits, water-use efficiency, and drought resistance. Agricultural Meteorology 14(1), 59-84. 
Huffman, D. W., Tappeiner II, J. C. (1997). Clonal expansion and seedling recruitment of Oregon grape (Berberis nervosa) in Douglas-fir (Pseudotsuga menziesii) forests: comparisons with salal (Gaultheria shallon). Canadian Journal of Forest Research, 27(11), 1788-1793.

Jones, H. (1998). Stomatal control of photosynthesis and transpiration. Journal of Experimental Botany, 49,387-398.

Klinka, K., Chen, H., Wang, Q., Montigny, L. (1996). Forest canopies and their influence on understory vegetation in early-seral stands on West Vancouver I sland. Northwest Science, 70(3), 193-200.

Knapp, A., Smith, W. (1989). Influence of growth form on ecophysiological responses to variable sunlight in subalpine plants. Ecology, 71(4), 1069-1082.

Kuhn, D. (2005). Fire in Forest Park. Environmental Science and Management. Portland State University, Portland, Oregon: Masters thesis.

Lee, C. (2002). Evolutionary genetics of invasive species. TRENDS in Ecology and Evolution, 17(8), 386-391.

Leuzinger, S., Hartmann, A., Korner, C. (2011). Water relations of climbing ivy in a temperate forest. Planta, 233, 1087-1096.

Levine, J., Vila, M., D Antonio, C., Dukes, J., Grigulis, J., Lavorel, S. (2003) Mechanisms underlying the impacts of exotic plant invasions. Proceedings of the Royal Society of Biological Sciences, 270,775-781.

Lezberg, A. L., Antos, J. A., Halpern, C. B. (1999). Belowground traits of herbaceous species in young coniferous forests of the Olympic Peninsula, Washington. Canadian Journal of Botany, 77(7), 936-943.

Lockwood, J., Hoopes, M., Marchellet, M. (2007). Invasion Ecology. Oxford: Blackwell Publishing.

Lockwood, J., Cassey, P., Blackburn, T. (2005). The role of propagule pressure in explaining species invasions. Trends in Ecology and Evolution, 20(5), 223-228.

Lockwood, J. L., Powell, R. D., Nott, M. P., \& Pimm, S. L. (1997). Assembling ecological communities in time and space. Oikos, 549-553.

Lonsdale, W. (1999). Global patterns of plant invasion and the concept of invasibility. Ecology, 80(5), 1552-1536. 
Lookingbill, T.,Goldenberg, N., Williams, B. (2004). Understory species as soil moisture indicators in Oregon's Western Cascades old-growth forests. Northwest Science, 78(3), 214-224.

McCulagh, P., Nelder, J. (1989). Generalized linear models, 2nd edition. London: Chapman \& Hall.

McKenzie, D., Halpern, C., Nelson, C. (2000). Overstory influences on herb and shrub communities in mature forests of western Washington, USA. Canadian Journal of Forest Research, 30, 1655-1666.

Metcalfe, D. (2005). Biological Flora of the British Isles. Journal of Ecology, 93: 632648.

Meyerson, L., Mooney, H. (2007). Invasive alien species in an era of globalization. Frontiers in Ecology and the Environment, 5(4), 199-208.

Miller, T., Mladenoff, D., Clayton, M. (2002). Old growth northern hardwood forests: spatial autocorrelation and patterns of understory vegetation. Ecological Monographs, 72(4), 487-503.

Mitchell, C., Agrawal, A., Bever, J., Gilbert, G., Haufbauer, R., Klironomos, J., Marion, J., Morris, W., Parker, I., Powers, A., Seabloom E., Torchin, M., Vazquez, D. (2006). Biotic interactions and plant invasions. Ecology Letters, 9(6), 726-740.

Munger, T. (1960). History of Portland's Forest Park. Portland, OR: Forest-Park Committee of Fifty.

Murray, F. (1967). On the computation of saturated vapor pressure. Journal of Applied Meterology, 6, 203-204.

Nelson, C., Halpern, C., Antos, J. (2007). Variation in responses of late-seral herbs to disturbance and environmental stress. Ecology, 88(11), 2880-2890.

Nilsson, M., Wardle, D.(2005). Understory vegetation as a forest ecosystem driver: Evidence from the Northern Swedish Boreal forest. Frontiers in Ecology and the Environment, 3(8), 421-428.

No Ivy League. (2005). Decennial Monitoring Report 1994-2004. Portland, OR.

North, M., Oakley, B., Fiegener, R., Gray, A., Barbour, M. (2005). Influence of light and soil moisture on Sierran mixed-conifer understory communities. Plant Ecology, $177,13-24$. 
(NRCS) Natural Resource Conservation Service (2014). Custom soil resource report for Multnomah County Area, Oregon.Web Soil Survey. Accessed 1/9/2014.

Retrieved from http://websoilsurvey.sc.egov.usda.gov/App/HomePage.htm .

(ODA) Oregon Department of Agriculture (2008). Nursery News. Accessed: August 2008. Retrieved from: http://www.oregon.gov.

(ODA) Oregon Department of Agriculture- Hedera helix (L.) Accessed February 2014 Retrieved from: http://www.oregon.gov.

Okerman, A. (2000). Combating the "Ivy Desert": The invasion of Hedera helix (English Ivy) in the Pacific Northwest United States. Restoration and Reclamation Review, 6(4), 1-10.

Pabst, R., Spies., T. (1997). Distribution of herbs and shrubs in relation to landform and canopy cover in riparian forests of coastal Oregon. Canadian Journal of Botany, 76(2), 298-315.

Parker, J., Richie, L., Lind,E., Maloney, K. (2009). Land use history alters the relationship between native and exotic plants: the rich don't always get richer. Biological Invasions, 12(6), 1557-1571.

Pimentel, D., Zuniga, R., Morrison, D. (2005). Update on the environmental and economic costs associated with alien-invasive species in the United States. Ecological Economics, 52(3) 273-288.

Pond, R. (April 13, 2003). Hydrophyllum tenuipes. University of Washington. Accessed: April 20, 2014. Retrieved from: http://depts.washington.edu/propplnt/Plants/.

Portland Parks and Recreation (02/26/2013). No Ivy League Project Statistics. Accessed February 2014. Retrieved from: https:/www.portlandoregon.gov/.

Quinn, H., Best, R. (2002). English ivy in Stanley Park: effects of the invasion and implications for management. Environmental Sciences, University of British Columbia: Master's Thesis.

R development Core Team (2008). R: A language and environment for statistical computing. R Foundation for Statistical Computing, Vienna, Austria.

Radosevich, S., Holt, J., Ghersa, C.(1997). Weed Ecology, Second Edition. Implications for Management. John Wiley \& Sons, Inc. New York, NY.

Ramsey, T. (2005). Invasion of English ivy ( Hedera spp., Araliaceae) into Pacific Northwest Forests. Biology, University of Washington, Seattle, WA: Dissertation. 
Reichard, S. (2000). Hedera helix. In: Bossard, Carla C.; Randall, John M.; Hoshovsky, Marc C., eds. Invasive plants of California's wildlands. Berkeley, CA: University of California Press: 212-216.

Richards, C., Bossdorf, O., Muth, N., Gurevitch, J., Pigliucci, M. (2006). Jack of all trades, master of some? On the role of phenotypic plasticity in plant invasions. Ecology Letters, 9, 981-993.

Sack, L., Cowan, P., Jaikumar, N., Holbrook, N. (2003). The 'hydrology' of leaves: coordination of structure and function in temperate woody species. Plant, Cell and Environment, 26, 1343-1356.

Scheller, R., Mladenoff, D. (2002). Understory patterns of diversity in old-growth and managed Northern hardwood forests. Ecological Applications, 23(5), 1329-1343.

Schnitzer, S., Bongers, F. (2011). The Ecology of lianas and their role in forests. Trends in Ecology and Evolution, 17(5), 223-229.

Schnitzler, Annik; Heuze, Patricia. (2006). Ivy (Hedera helix L.) dynamics in riverine forests: effects of river regulation and forest disturbance. Forest Ecology and Management. 236(1), 12-17.

Schnitzer, S., Kuzeee, M., Bongers, F. (2005). Disentangling above-and below-ground competition between lianas and trees in a topical forest. Journal of Ecology, 93(6), 1115-1125.

Sexton, J., McKay, J., Sala, A. (2002). Plasticity and genetic diversity may allow saltcedar to invade cold climates in North America. Ecological Applications, 12(6), 1652-1660.

Silvertown, J., Franco, M., Pisanty, I., Mendoza, A. (1993). Comparative plant demography-Relative importance of life-cycle components to the finite rate of increase in woody and herbaceous perennials. Journal of Ecology, 81(3), 465-476.

Simblerloff, D. (2009). The role of propagule pressure in biological invasions. Annual Review of Ecology, Evolution, and Systematics. 40, 81-102.

Soll, J. (2005). Controlling English ivy in the Pacific Northwest. The Nature Conservancy. Accessed May 2013.

Retrieved from: http://www.invasive.org/gist/moredocs/hedhel02.pdf.

Soltis, P., Soltis, D. (1987). Population structure and estimates of gene flow in the homosporous fern Polysticum munitum. Evolution, 41(3), 620-629. 
Sorensen, A. (1984). Nutrition, energy and passage time: experiments with fruit preference in European blackbirds (Turdus merula). Journal of Animal Ecology, $53,545-557$.

Smith, B., Wilson, J. (1996). A Consumer's Guide to Evenness Indices. Okios, 76(1), 7082 .

Spies, T., Franklin, J. (1991). The structure of natural young, mature, and old-growth Douglas-fir forests in Oregon and Washington. Wildlife and vegetation of unmanaged Douglas-fir forests. USDA Forest Service General Technical Report PNW-GTR-285, Portland, USA. Pacific Northwest Research Station, 91-111.

Spellerberg, I., Fedor, P. (2003). A tribute to Claude Shannon (1916-2001) and a plea for more rigorous use of species richness, species diversity, and the Shannon-Wiener' Index. Global Ecology and Biogeography, 12, 177-179.

Stinson, K., Kaufman, S., Durbin, L., Lowenstein, F. (2007). Impacts of garlic mustard I invasion on a forest understory community. Northeastern Naturalist. 14(1), 73-88.

Swearingen, J.M. and S. Diedrich. (2009). Fact Sheet: English Ivy. Plant Conservation Alliance's Alien Plant Working Group. Accessed February 23, 2014. Retrieved from: http://www.nps.gov/plants/alien/fact/hehe1.htm.

Tomasetto, F., Duncan, R., Hulme, P. (2013). Environmental gradients shift the direction of the relationship between native and alien plant species richness. Diversity and Distribution, 19, 49-59.

Thomas, L. K. (1998). Topographic Alterations, Forest Structure, and Invasion by English Ivy (Hedera helix L.) in the Rock Creek Floodplain, Washington, D. C. Natural Areas Journal, 18(2), 164-168.

Thomas, L. K. (1980). The impact of three exotic plant species on a Potomac island. National Park Service Scientific Monograph Series No. 13. Washington, DC: U.S. Department of the Interior, National Park Service. 179 p.

Thomas, S., Halpern, C., Falk, D., Liguori, D., Austin, K. (1999). Plant diversity in managed forests: Understory responses to thinning and fertilization. Ecological Applications, 9(3), 864-879.

Tilman, D.. (1986). Resources, competition and the dynamics of plant communities. 51-75 in M.J. Crawley, Plant Ecology. Massachusetts, USA: Blackwell Scientific. 
Tilman, D., Grace, J. B. (1990). Mechanisms of plant competition for nutrients: the elements of a predictive theory of competition. Perspectives on plant competition, 117-141.

Tirmenstein, D. (1989). Rubus ursinus. Fire Effects Information System.

U.S. Department of Agriculture, Forest Service, Rocky Mountain Research Station, Fire Sciences Laboratory. Accessed: March 25, 2014. Retrieved from: http://www.fs.fed.us/database/feis/.

Turner, N., Begg, J. (1981). Plant-water relations and adaptation to stress. Plant and Soil $58,97-131$.

Tuzet, A., Perrier, A., Leuning, R. (2003). A coupled model of stomatal conductance, photosynthesis and transpiration. Plant, Cell and Environment, 26, 1097-1116.

Urgenson, L., Reichard, S., Halpern, C. (2009). Community and ecosystem consequences of giant knotweed (Polygonum sachalinense) invasion into riparian forests of western Washington, USA. Biological Conservation, 142,1536-1541.

USDA, Natural Resources Conservation Service. 2014a. PLANTS Database, Hedera helix L. Accessed: Retrieved February 2014. Retrieved from: http://plants.usda.gov/core/profile?symbol=HEHE.

USDA, Natural Resources Conservation Service. 2012b. PLANTS Database, Hedera hibernica (G Kirchn)Bean. Accessed February 2014. Retrieved fro: http://plants.usda.gov/core/profile?symbol=HEHI12.

Vander Schaaf, D., G. Wilhere, Z. Ferdaña, K. Popper, M. Schindel, P. Skidmore, D. Rolph, P. Iachetti, G. Kittel, R. Crawford, D. Pickering, and J. Christy. (2006). Pacific Northwest Coast Ecoregion Assessment. Prepared by The Nature Conservancy, the Nature Conservancy of Canada, and the Washington Department of Fish and Wildlife. The Nature Conservancy, Portland, Oregon.

Violle, C., Gamier, E., Lecoeur, J., Roumet, C., Podeur, C., Blanchard, A., Navas, M. (2009). Competition, traits and resource depletion in plant communities. Oecologia, 160(4) 747-755.

Waggy, M. A. (2010). Hedera helix. Fire Effects Information System, U.S. Department of Agriculture, Forest Service, Rocky Mountain Research Station, Fire Sciences Laboratory. Accessed January 26, 2014. Retrieved from: http://www.fs.fed.us/database/feis/.

Waring, R., Franklin, J. (1979). Evergreen coniferous forests of the Pacific Northwest. Science, New Series, 204(4400), 1380-1386. 
Western, A. W., Grayson, R. B., \& Blöschl, G. (2002). Scaling of soil moisture: A hydrologic perspective. Annual Review of Earth and Planetary Sciences, 30(1), $149-180$.

Williams, M., Fitter, A. (1996). The characters of successful invaders. Biological Conservation, 78, 163-170.

Wisehard, L., Kaye, T., Kirkland, M. (July 2011). Field guide to weeds of the Willamette Valley. Institute for Applied Ecology, Third printing. Accessed: January 2014. Retrieved from: www.appliedeco.org.

Yeakley, J., Swank, W., Swift, L., Horberger, G., Shugart, H. (1998). Soil moisture gradients and controls on a southern Appalachian hillslope from drought through recharge. Hydrology and Earth Systems Sciences, 2(1), 41-49.

Zeileis A, Kleiber C, Jackman S (2008). Regression models for count data in R. J Stat Software 27:1-25.

Zhu, S., Cao, K. (2009). Hydraulic properties and photosynthetic rates in co-occurring lianas and trees in a seasonal tropical rainforest in Southwestern China. Plant Ecology, 204(2), 295-304. 
Appendix 1: All species (common and scientific name) recorded in Balch Research Plot in the 2010 field season and in both Balch and Coyote Research Plots in the 2013 field season. Species are divided into functional group.

\begin{tabular}{|c|c|c|c|c|c|}
\hline \multicolumn{2}{|c|}{2010 Balch Creek Research Site } & \multicolumn{2}{|c|}{2013 Balch Creek Research Site } & \multicolumn{2}{|c|}{2013 Coyote Research Site } \\
\hline \multicolumn{2}{|c|}{ herb } & \multicolumn{2}{|c|}{ herb } & \multicolumn{2}{|c|}{ herb } \\
\hline Scientific Name & Common Name & Scientific Name & Common Name & Scientific Name & Common Name \\
\hline Achlys triphylla & vanillaleaf & Achlys triphylla & vanillaleaf & Achlys triphylla & vanillaleaf \\
\hline Anemone deltoidea & three-leaf anemone & Asarum caudatum & wild ginger & Adenocalulon bicolor & pathfinder \\
\hline Asarum caudatum & wild ginger & Circaea alpina & enchanters nightshade & Anemone deltoidea & three-leaf anemone \\
\hline Claytonia sibircia & Siberian candy flower & Claytonia sibircia & Siberian candy flower & Asarum caudatum & wild ginger \\
\hline Disporum hookeri & Hooker's fairybells & Dicentra formosa & bleeding heart & Carex spp. & sedge \\
\hline Galium triflorum & Sweet-scented bedstraw & Disporum hookeri & Hooker's fairybells & Circaea alpina & enchanters nightshade \\
\hline Hydrophyllum tenuipes & Pacific waterleaf & Galium triflorum & sweet-scented Bedstraw & Claytonia sibircia & Siberian candy flower \\
\hline Osmorhiza chilensis & mountain sweet-cicely & Hydrophyllum tenuipes & Pacific waterleaf & Disporum hookeri & Hooker's fairybells \\
\hline Smilacina stellata & starry solomans seal & Osmorhiza chilensis & mountain sweet-cicely & Festuca spp. & ffFescue \\
\hline Streptopus amplexifolius & twisted stalk & Oxalis spp. & sorrel spp. & Galium aparine & cleavers \\
\hline Tiarella trifoliata & foamflower & Smilacina racemosa & false solomans seal & Galium triflorum & sweet-scented Bedstraw \\
\hline Tolmiea menziesii & piggy-back plant & Smilacina stellata & $\begin{array}{l}\text { starry solomans seal } \\
\text { s. }\end{array}$ & Hydrophyllum tenuipes & Pacific waterleaf \\
\hline Trillium ovatum & Pacific trillium & Streptopus amplexifolius & twisted stalk & Maianthemum dilatatum & False lily of the valley \\
\hline Vancouveria hexandra & inside-out-flower & \begin{tabular}{|l} 
Tiarella trifoliata \\
Tolmie trenziesii
\end{tabular} & foamflower & Osmorhiza chilensis & mountain sweet-cicely \\
\hline \multicolumn{2}{|c|}{ shrub and vine } & Trientalis latifolia & $\begin{array}{l}\text { p1ggy-oack plant } \\
\text { broad-leaf starflower }\end{array}$ & $\begin{array}{l}\text { Oxans spp. } \\
\text { Smilacina stellata }\end{array}$ & $\begin{array}{l}\text { starry solomans seal } \\
\text { solo }\end{array}$ \\
\hline \multirow{5}{*}{$\begin{array}{l}\text { Mahonia nervosa } \\
\text { Rubus parviflorus } \\
\text { Rubus spectabilis } \\
\text { Rubus ursinus } \\
\text { Vaccinium parvifolium }\end{array}$} & \multirow{5}{*}{$\begin{array}{l}\text { Oregon grape } \\
\text { thimbleberry } \\
\text { trailing blackberry }\end{array}$} & Trillium ovatum & Pacific trillium & \multirow{6}{*}{$\begin{array}{l}\text { Tolmiea menziesii } \\
\text { Trientalis latifolia } \\
\text { Trillium ovatum } \\
\text { Vancouveria hexandra } \\
\text { Veronica spp. } \\
\text { Viola glabella } \\
\end{array}$} & piggy-back plant \\
\hline & & Vancouveria hexandra & inside-out-flower & & broad-leaf starflower \\
\hline & & Veronica spp. & speedwell spp. & & Pacific trillium \\
\hline & & abella & stream viol & & inside-out-flower \\
\hline & & \multicolumn{2}{|c|}{ shrub and vine } & & speedwell spp. \\
\hline \multicolumn{2}{|c|}{ fern and allies } & Acer circinatum & vine maple & & รูstream violet \\
\hline \multirow{5}{*}{\begin{tabular}{|l} 
Adiantum pedatum \\
Athyrium filix-femina \\
Monotropa uniflora \\
Polystichum munitum \\
Pteridium aquillinum
\end{tabular}} & \multirow{5}{*}{$\begin{array}{l}\text { maidenhair fern } \\
\text { ladyfern } \\
\text { indianpipe } \\
\text { sword fern } \\
\text { braken fern }\end{array}$} & Mahonia nervosa & Oregon grape & \multicolumn{2}{|c|}{ shrub and vine } \\
\hline & & Oemleria cerasiformis & Indian plum & \multirow{6}{*}{$\begin{array}{l}\text { Mahonia nervosa } \\
\text { Rubus discolor } \\
\text { Rubus spectabilis } \\
\text { Rubus ursinis } \\
\text { Sambucus racemosa } \\
\text { Vaccinium parvifolium }\end{array}$} & Oregon grape \\
\hline & & Rosa gymnocarpa & dwarf rose & & Himalayan blackberry \\
\hline & & Rubus parviflorus & thimbleberry & & salmonberry \\
\hline & & Rubus spectabilis & salmonberry & & trailing blackberry \\
\hline \multirow{8}{*}{$\begin{array}{l}\text { Non } \\
\text { Circaea alpina } \\
\text { Clematis vitalba } \\
\text { Geranium robertianum } \\
\text { Hedera spp. } \\
\text { Lactuca muralis } \\
\text { Rubus discolor } \\
\text { Solanum dulcamara }\end{array}$} & tive spp. & Rubus ursinis & trailing blackberry & & red elderberry \\
\hline & \multirow{7}{*}{$\begin{array}{l}\text { Cenchanters nightshade } \\
\text { Chematis } \\
\text { English ivy } \\
\text { Wall lettuce } \\
\text { himilayan blackberry } \\
\text { bittersweet nightshade }\end{array}$} & Sambucus racemosa & red elderberry & & red huckleberry \\
\hline & & Vaccinium parvifolium & red hu & \multicolumn{2}{|c|}{ fern and allies } \\
\hline & & \multicolumn{2}{|c|}{ fern and allies } & Athyrium filix-femina & ladyfern \\
\hline & & \multirow{5}{*}{\begin{tabular}{|l|} 
Adiantum pedatum \\
Athyrium filix-femina \\
Equisetum arvense \\
Polystichum munitum \\
Pteridium aquillinum
\end{tabular}} & maidenhair fern & Polystichum munitum & stord fern \\
\hline & & & ladyfern & \multicolumn{2}{|c|}{ Nonnative spp. } \\
\hline & & & horsetail & \multirow{6}{*}{\begin{tabular}{|l|} 
Clematis vitalba \\
Geranium robertianum \\
Hedera spp. \\
Ilex aquifolium \\
Lactuca muralis \\
Ranunculus repens \\
\end{tabular}} & chematis \\
\hline & & & sword fern & & herb- Robert \\
\hline & & & braken fern & & English ivy \\
\hline & & & & & English Holly \\
\hline & & \begin{tabular}{|l|} 
Clematis vitalba \\
Geranium robertianum
\end{tabular} & $\begin{array}{l}\text { clematis } \\
\text { herb- Robert }\end{array}$ & & $\begin{array}{l}\text { wall lettuce } \\
\text { creeping buttercup }\end{array}$ \\
\hline & & $\begin{array}{l}\text { Hedera spp. } \\
\text { Ilex aquifolium } \\
\text { Ranunculus repens }\end{array}$ & $\begin{array}{l}\text { English ivy } \\
\text { English Holly } \\
\text { creeping buttercup }\end{array}$ & & \\
\hline
\end{tabular}

